University of Nebraska - Lincoln

DigitalCommons@University of Nebraska - Lincoln

\title{
Abundance and distribution of selected elements in soils, stream sediments, and selected forage plants from desert tortoise habitats in the Mojave and Colorado deserts, USA
}

\author{
M. A. Chaffee \\ U.S. Geological Survey, mchaffee@usgs.gov \\ K. H. Berry \\ Western Ecological Research Center
}

Follow this and additional works at: https://digitalcommons.unl.edu/usgsstaffpub

Part of the Earth Sciences Commons

Chaffee, M. A. and Berry, K. H., "Abundance and distribution of selected elements in soils, stream sediments, and selected forage plants from desert tortoise habitats in the Mojave and Colorado deserts, USA" (2006). USGS Staff -- Published Research. 366.

https://digitalcommons.unl.edu/usgsstaffpub/366

This Article is brought to you for free and open access by the US Geological Survey at DigitalCommons@University of Nebraska - Lincoln. It has been accepted for inclusion in USGS Staff -- Published Research by an authorized administrator of DigitalCommons@University of Nebraska - Lincoln. 
Journal of

\title{
Abundance and distribution of selected elements in soils, stream sediments, and selected forage plants from desert tortoise habitats in the Mojave and Colorado deserts, USA
}

\author{
M.A. Chaffee ${ }^{\mathrm{a}, *}$, K.H. Berry ${ }^{\mathrm{b}}$ \\ ${ }^{a}$ US Geological Survey, Geologic Division, Federal Center, MS 973, Denver, CO USA 80225 \\ ${ }^{\mathrm{b}}$ Western Ecological Research Center, 22835 Calle San Juan de Los Lagos, Moreno Valley, CA 92553, USA
}

Received 3 March 2004; received in revised form 30 July 2004; accepted 20 January 2005

\begin{abstract}
A baseline and background chemical survey was conducted in southeastern California, USA, to identify potential sources of toxicants in natural and anthropogenically-altered habitats of the threatened desert tortoise (Gopherus agassizii). Soil, stream sediment, and plant samples were collected from six tortoise habitat study areas in the Mojave and Colorado deserts and analysed for up to 66 different elements. The chemical analyses provided new information on the abundances and distributions of selected elements in this region. Soil, stream-sediment, and plant analyses showed distinct variations in bulk chemistries from locality to locality. Variations were, in general, consistent with the many types of exposed rock units in the region, their highly variable bulk mineralogies, and chemical contents. Of elements in soils that might have been toxic to tortoises, only As seemed to be anomalous region-wide. Some soil and plant anomalies were clearly anthropogenic. In the Rand and Atolia mining districts, soil anomalies for $\mathrm{As}, \mathrm{Au}, \mathrm{Cd}, \mathrm{Hg}, \mathrm{Sb}$, and(or) $\mathrm{W}$ and plant anomalies for As, $\mathrm{Sb}$, and(or) $\mathrm{W}$ extend as far as $\sim 15 \mathrm{~km}$ outward from the present area of mining; soils containing anomalous $\mathrm{Hg}$ were found at least $6 \mathrm{~km}$ away from old piles of tailings. The anomalous concentrations of As and $\mathrm{Hg}$ may have been the source of elevated levels of these elements found in ill tortoises from the region. In the Goldstone mining district, soil anomalies extended several $\mathrm{km}$ from the mining area. These areas probably represented anthropogenic surface contamination of dust redistributed by wind, vehicles, and rainfall. One of two study areas transected by a paved road (Chemehuevi Valley) showed weakly elevated levels of $\mathrm{Pb}$, which extended as far as $\sim 22 \mathrm{~m}$ from the pavement edge and were probably related to vehicle exhaust. No soil or plant samples from
\end{abstract}

\footnotetext{
${ }^{*}$ Corresponding author. Tel.: +13032361855.

E-mail address: mchaffee@usgs.gov (M.A. Chaffee).
} 
historically used military areas (Goldstone, Goffs, Chemehuevi Valley, Chuckwalla Bench) contained anomalous concentrations of the elements $\mathrm{As}, \mathrm{Cu}, \mathrm{Cr}, \mathrm{Fe}, \mathrm{Pb}$, or $\mathrm{Zn}$ that could be ascribed to military maneuvers, vehicles, or ordnance. For future studies, the distribution and abundance of elements in the tortoise forage plants need to be evaluated for the respective roles of dust and systemic uptake. Additional chemical data from tortoise necropsies and nutritional studies are needed to determine the effects of potentially toxic elements in tortoise habitats on their health. (C) 2006 Elsevier Ltd. All rights reserved.

Keywords: Geochemistry; Soils; Sediments; Plants; Gopherus agassizii; Contaminants; Arsenic

\section{Introduction}

\subsection{Desert tortoises}

The desert tortoise (Gopherus agassizii), once common in the southwestern United States, was listed in 1990 as a threatened species under the Endangered Species Act of 1973 (as amended) in the northern third of its geographic range (Fish and Wildlife Service [FWS], 1990). The populations experiencing declines are in the Mojave and Colorado (western Sonoran) deserts, and the causes are numerous (FWS, 1990, 1994). To assist in recovery of this flagship and umbrella species (Simberloff, 1998), the FWS and other agencies protected $18,163 \mathrm{~km}^{2}$ of critical habitat in the Mojave Desert and $7924 \mathrm{~km}^{2}$ in the Colorado Desert (FWS, 1994; Berry, 1997).

Loss of and deterioration to habitats have contributed to population declines, as have potentially new, or recently identified diseases such as upper respiratory tract disease (URTD) (Jacobson et al., 1991; Brown et al., 1994, 1999) and shell diseases (Jacobson et al., 1994; Homer et al., 1998). These diseases may be exacerbated by elemental toxicity. For example, in one study of URTD, the livers of ill, wild tortoises had 11 times the levels of mercury compared with healthy control tortoises (Jacobson et al., 1991). In addition, several potentially toxic elements have been found in elevated concentrations in tissues of ill tortoises salvaged for necropsy from southeastern California but not in healthy tortoises used as controls, including arsenic (Berry et al., 2001; Seltzer and Berry, 2005).

Desert tortoises spend much of their lives in contact with dust, soil, and sediments. They live underground $\sim 95 \%$ of the year in burrows or caves (Nagy and Medica, 1986), sniff soil frequently (Berry, 1986; Ruby and Niblick, 1994), and occasionally consume soil (Marlow and Tollestrup, 1982). In addition, they are herbivorous (Burge and Bradley, 1976; Jennings, 1993, 2002; Oftedal, 2002; Van Devender et al., 2002), and consumed plants are often dusty. Although tortoises have many adaptations and exaptations to deal with droughts that commonly occur in desert ecosystems (Henen et al., 1998; Berry et al., 2002; Morafka and Berry, 2002), some of these same adaptations or exaptations may contribute to concentrations of potentially toxic substances in their tissues during drought years when free water in the form of rain and succulent green forage are unavailable.

\subsection{Geology and geochemistry}

The natural surface chemistry of southeastern California is largely dictated by the local geology. The geology is complex (Jennings et al., 1962; Walker et al., 2002), many different 
rock types are present, and the bulk chemistries of rocks and their weathering products vary widely. Locally, anthropogenic activity, such as mining, recreation, or military use, may add element concentrations to those of the natural surface chemistry derived from local geology. The chemistry of surface materials such as soil and stream sediments may be, in turn, assimilated by plants, including species consumed by desert tortoises. Thus, the surface chemistry of tortoise habitats may have an impact on their health.

\subsection{Purposes of the investigation}

The purposes of this investigation were two-fold. First, we determined the chemical content (abundance) of selected elements in samples of soil, stream sediment, and(or) plants collected in six desert tortoise habitat study areas and in the region as a whole that encompasses these six areas. Geometric mean values for selected elements were used to identify those elements that were relatively enriched in a given sample medium or area. The data in a series of tables also provided reference values useful for further environmental investigations.

Second, we delineated the distributions of anomalous concentrations of selected elements in the three sample media to identify their location, extent, and possible sources. Anomalous abundances and distributions identified in this investigation provided chemical information that can be used in conjunction with necropsy and other tortoise data to determine whether high concentrations of various elements in soil, stream sediment, and(or) plants may be contributing to the increasing mortality rates and signs of disease associated with elemental toxicity.

\section{Methods}

\subsection{Descriptions of the study areas}

We selected for detailed investigation six study areas in the Mojave and Colorado deserts of southeastern California (Fig. 1) that contain Federally designated "critical habitat" or otherwise protected habitat (FWS, 1994) for the tortoise. Tortoise populations in these areas were, in recent history (1970s-1980s) of moderate to high densities (FWS, 1994).

\subsubsection{Western Mojave-Southern Section}

We investigated a $1385 \mathrm{~km}^{2}$ area in the western Mojave Desert (Fig. 1). The northern part is strongly mineralized and has been extensively prospected and disturbed by mining, whereas the southern part is relatively unmineralized and undisturbed. Because of these differences, the area was divided into southern and northern sections. The Southern Section $\left(789 \mathrm{~km}^{2}\right)$ extends from the central part of the Rand Mountains southward to the vicinity of California City. The center of the Southern Section contains exposures of granite in the southern Rand Mountains and adjoining pediment surfaces (Fig. 2). Pediments surrounding granite outcrops are composed of gravels and active stream sediments derived from granite (Jennings et al., 1962). Elevations vary from $579 \mathrm{~m}$ at Koehn Dry Lake to $1220 \mathrm{~m}$ in the central Rand Mountains. No significant mining or other anthropogenic activity has occurred. The vegetation is dominated by Larrea tridentata, a typical species of the Mojave Desert. Several other perennial shrubs are also common, such 


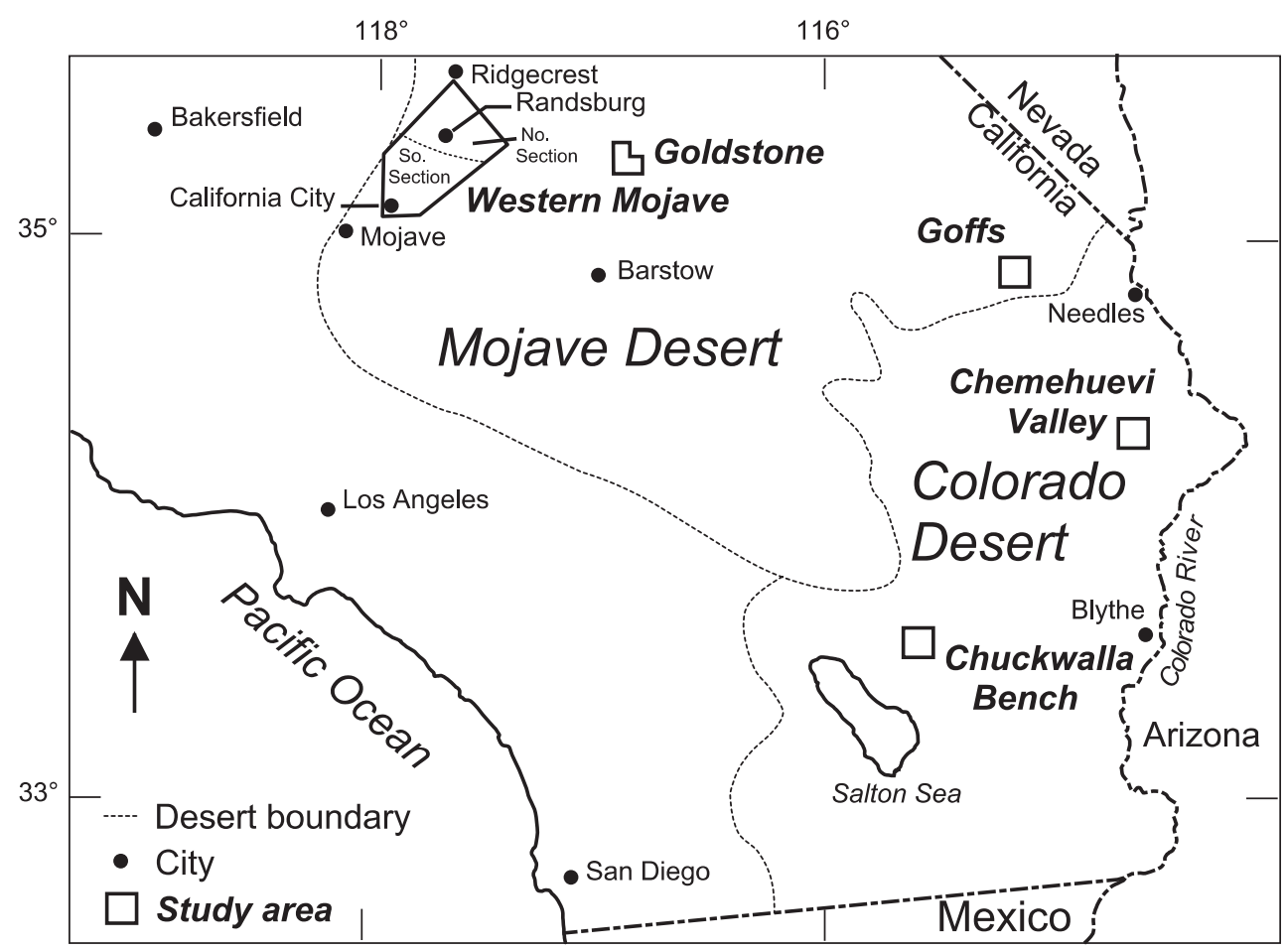

Fig. 1. Map of southern California, USA, showing locations of six study areas.

as Ambrosia dumosa, Acamptopappus sphaerocephalus, Lycium andersoni, and Hymenoclea salsola.

\subsubsection{Western Mojave-Northern Section}

This $596 \mathrm{~km}^{2}$ study area extends from the central Rand Mountains on the south and west, eastward to Cuddeback Dry Lake (elev. range $\sim 664-1604 \mathrm{~m}$ ) and northward beyond the town of Randsburg (Fig. 2). Extensive rock outcrops containing granite, granodiorite, quartz monzonite, quartz diorite, rhyolite, latite, andesite, and quartz-rich mica schist are exposed (Hess, 1910; Lemmon and Dorr, 1941; Jennings et al., 1962; Troxel and Morton, 1962; Walker et al., 2002; Fig. 2). Granite is exposed in the extreme southern part of this section. All rock exposures are surrounded by pediments containing thick sequences of unconsolidated to consolidated alluvial gravels and active stream sediments, and locally, lake-bed sediments, all composed of material from surrounding areas of outcrop. The vegetation reflects the elevational range, with creosote bush scrub, a mixed desert scrub, and Yucca brevifolia at higher elevations and a saltbush community dominated by Atriplex polycarpa at the eastern edge of the study area near Cuddeback Dry Lake.

The Northern Section includes the major Rand (or Randsburg) mining district, in the vicinity of the town of Randsburg (Fig. 2). This district was prospected as early as the 1860s. Mining began in the 1890s, with Au and W the main commodities mined, along with minor amounts of $\mathrm{Ag}$, $\mathrm{As}, \mathrm{Cu}, \mathrm{Pb}$, and Sb (Hess, 1910; Hulin, 1925; Troxel and Morton, 1962; Clark, 1970). Gold has recently been mined from an open pit just south of 


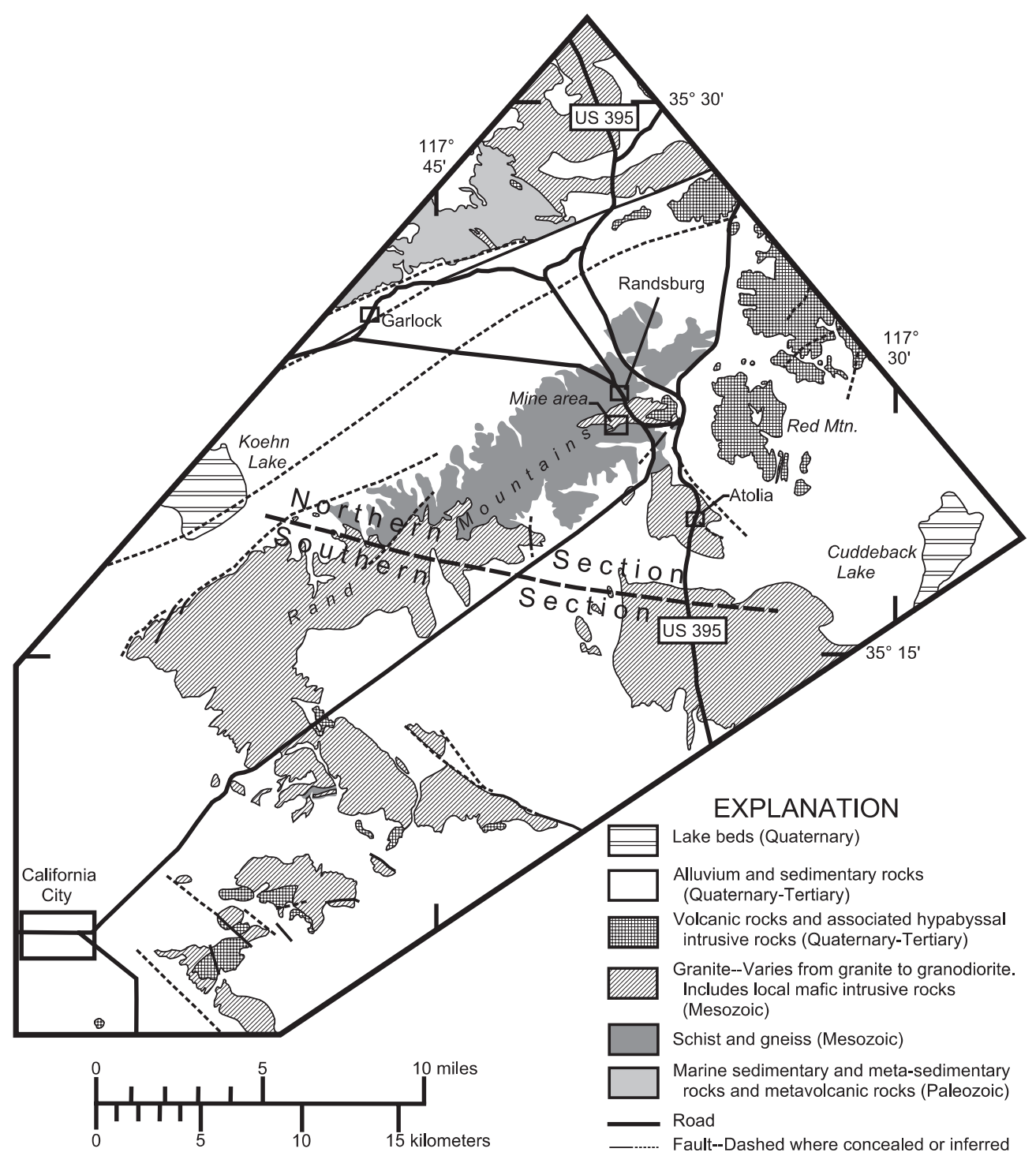

Fig. 2. Generalized geologic map, Western Mojave Study Area, California, USA. Geology modified from Jennings et al. (1962).

Randsburg. Tungsten was mined in the past in the Atolia district. Minor amounts of minerals containing $\mathrm{As}, \mathrm{Au}, \mathrm{Cu}, \mathrm{Hg}$, and $\mathrm{Sb}$ have been reported in $\mathrm{W}$ ores (Hulin, 1925; Lemmon and Dorr, 1941). Extensive dumps and abandoned tailing piles are present in a number of localities in the two districts.

\subsubsection{Goldstone}

This study area is part of the Goldstone Deep Space Communications Center, in and adjacent to the southwestern corner of the National Training Center, Fort Irwin (Fig. 1). 
Elevations range from $\sim 920$ to $1487 \mathrm{~m}$. Basins filled with thick sequences of alluvial gravels, stream sediment, or lake-bed sediments surround extensive outcrops of granite, schist, basalt, andesite, and latite tuff, as well as fresh and altered carbonate-rich sedimentary rocks (Jennings et al., 1962; Miller and Sutter, 1982; Fig. 3). Most rock types found in outcrop are also present in surrounding basin sediments. The Goldstone mining district, which is just south of the southern boundary of the National Training Center, Fort Irwin, was actively mined in the early part of the 20th Century (Cloudman et al., 1919). The wide range of elevations supports vegetation types similar to those in the Western Mojave Study Area. At higher elevations, common perennial species include $Y$. brevifolia and mixed desert scrub composed of the A. dumosa, A. sphaerocephalus, L. andersonii, and $H$. salsola along with Atriplex confertifolia, Grayia spinosa, and Krascheninnikovia lanata. At lower elevations near Goldstone Lake, species preferring alkaline soils, such as $A$. polycarpa and $A$. confertifolia, are common.

\subsubsection{Goffs}

The study area (elev. $\sim 110-720 \mathrm{~m}$ ) is located along the main line of the Burlington Northern and Santa Fe Railroad and the adjacent Goffs Road, an abandoned part of US Highway 66 (a once heavily traveled, paved highway) (Fig. 1). Various old alignments of this historic route are evident west of and adjacent to the existing paved road. Road

\section{EXPLANATION}

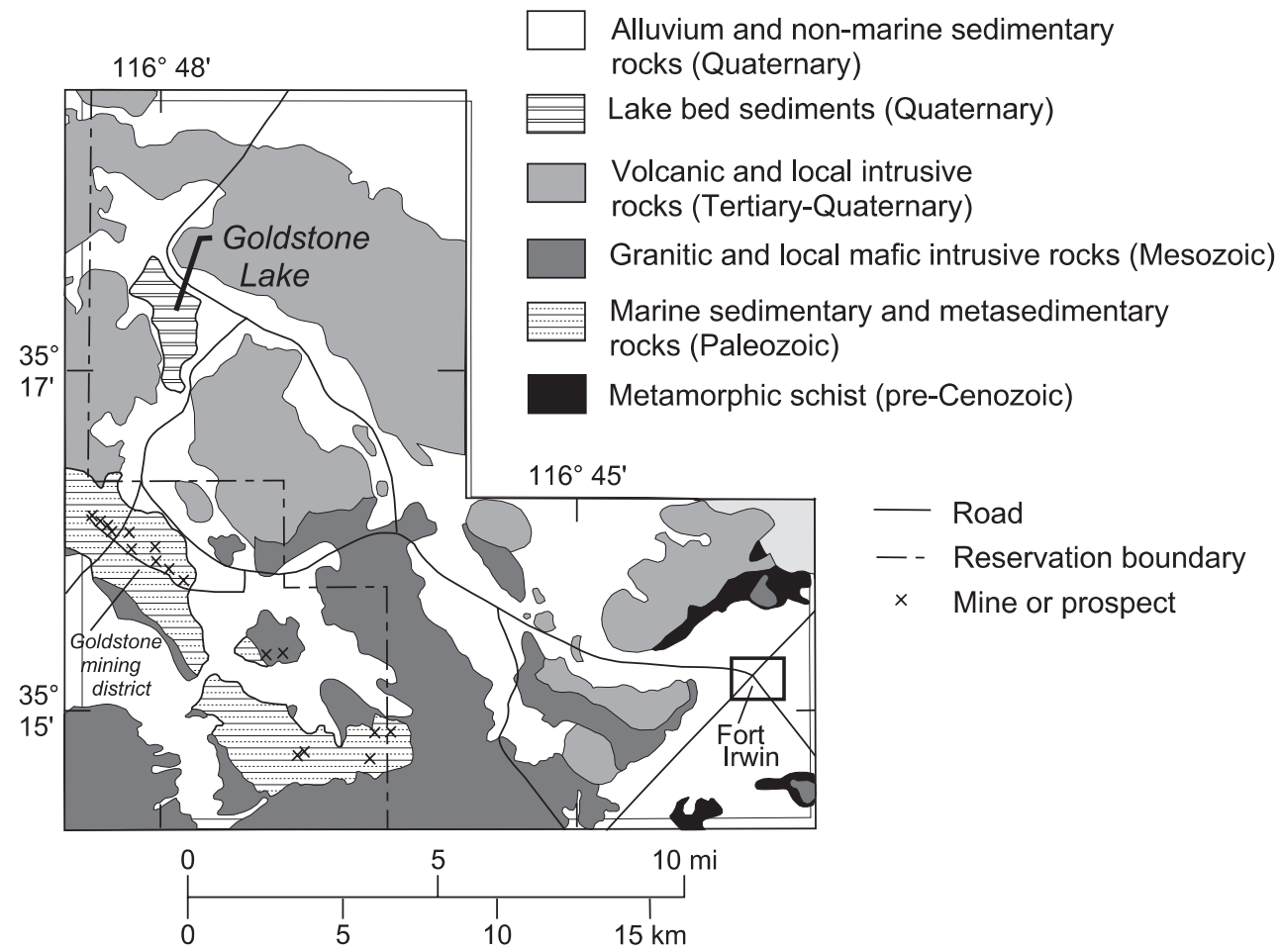

Fig. 3. Generalized geologic map, Goldstone Study Area, Central Mojave Desert, California, USA. Geology modified from Jennings et al. (1962). 
shoulders and drainage channels beneath railroad bridges are frequently scraped with bulldozers, creating new berms and enlarging existing berms. The area was widely disturbed as a result of military training exercises during World War II (Prose, 1985). The surface in and near the study area contains no outcrops and is composed of a thick sequence of unsorted alluvium and gravels. The lithologic composition of these sediments reflects rock units exposed in surrounding mountains and pediments. Rock types commonly present in sediments include granite gneiss, schist, and latite tuff. No mining has occurred in the immediate area, and none of the rock fragments examined exhibits material commonly associated with mineral deposits, such as sulfide minerals. Common perennial plant species are L. tridentata, A. dumosa, Krameria erecta, Pleuraphis rigida, Opuntia basilaris, O. echinocarpa, O. ramosissima, and Acacia greggii.

\subsubsection{Chemehuevi Valley}

This study area is in the eastern part of the Colorado Desert (Fig. 1) and is adjacent to US Highway 95, a heavily traveled, paved highway. The highway alignment has shifted about $100 \mathrm{~m}$ from east to west during the last $100 \mathrm{yr}$, and remnants of the old road bed and asphalt are still evident east of the current paved highway. Remains of an abandoned air strip are present along the west side of the highway. This portion of Highway 95 has frequently flooded, and in recent years, the roadbed was raised and a $\sim 5 \mathrm{~m}$-high artificial berm was constructed to reduce flooding. No mining has occurred; however, scars from military training exercises during World War II are still evident (Prose, 1985).

The Chemehuevi Valley Study Area is one of low relief (elev. 335-354 m). No outcrops are present, and surfaces in and around the area consist of a thick sequence of unsorted alluvium and gravels. The lithologic composition of these sediments reflects rock units exposed in surrounding mountains, including granite, granite gneiss, basalt, and andesite. None of the rock fragments examined exhibits material commonly associated with mineral deposits. Washes commonly exhibit streaks of sediment enriched in magnetite and other heavy minerals, as well as Mn oxide coatings on some grains or rock fragments. Perennial plant species are typical of the Colorado Desert and include Fouquieria splendens, Cercidium floridum, A. greggii, L. tridentata, A. dumosa, and H. salsola.

\subsubsection{Chuckwalla Bench}

Chuckwalla Bench, the southernmost area investigated (Fig. 1), is located along the unpaved Bradshaw Trail Highway, $\sim 18 \mathrm{~km}$ south of Interstate Highway 40 and just north of the northern boundary of the Chocolate Mountains Aerial Gunnery Range, at elevations of $\sim 610-701 \mathrm{~m}$. The study area contains only one small outcrop, which is composed of gneiss. The rest of the area contains a thick sequence of unsorted alluvium and gravels. The lithologic composition of these sediments reflects rock units exposed in surrounding mountains, including granite, gneiss, schist, felsic volcanic tuffs, basalt, and andesite. No mining has occurred, and none of the rock fragments examined exhibits material commonly associated with mineral deposits. Washes and soils are as described for the Chemehuevi Valley Study Area. Scars from military training exercises during World War II are still evident on desert pavement surfaces (Prose, 1985). Perennial plant species are similar to those at Chemehuevi, only with more diversity. Trees in the microphyll woodland washes include Psorothamnus spinosus, Olneya tesota, and C. floridum. Shrubs include F. splendens, L. tridentata, A. dumosa, H. salsola, Simmondsia chinensis, Hyptis emoryi, and many other species. 


\subsection{Collection and preparation of soil, stream sediment, and plant samples}

Between 1997 and 2001, we collected samples of soil, stream sediment, and plants from scattered sites and traverses in selected areas in southern California. These samples were collected and prepared for analysis as described below.

\subsubsection{Soils}

Before we conducted our regional soil survey, we collected soil profiles from 27 sites in an area of the Rand Mountains suspected to be contaminated by mining activity to evaluate the methodology. At each site, the soil surface was first scraped away to a depth of $\sim 2 \mathrm{~cm}$ to remove litter and any organic material. Samples were then collected at depths of $\sim 2-8$ and $\sim 8-20 \mathrm{~cm}$. Analyses of soil samples collected in these vertical profiles indicated that the $\sim 2-8 \mathrm{~cm}$ part of the soil profile consistently contained more of the eoliantransported, mining-related contaminants, such as $\mathrm{Ag}$, As, $\mathrm{Au}, \mathrm{Sb}$, and $\mathrm{W}$, than did the $\sim 8-20 \mathrm{~cm}$ part. We observed that this $\sim 2-8 \mathrm{~cm}$ zone also contained most of the roots of annual and perennial plant species we sampled and therefore had most strongly influenced the chemistry of these plant species. Based on this information, other soil samples were collected wherever possible from this $\sim 2-8 \mathrm{~cm}$ part of the soil profile. All soil samples were deemed to be immature and contained very little organic material.

We collected and analysed 256 samples for the regional soil data set (Tables 1 and 2). Individual soil samples were composited from three or more locations within a radius of $\sim 10 \mathrm{~m}$ of the center of a given sampling site. The soil composite was then sieved through stainless-steel sieves, and material passing a $0.18-\mathrm{mm}$ opening $(-80 \mathrm{mesh})$ was retained for analysis. This fine material was pulverized to about $0.10 \mathrm{~mm}$-sized material $(-150 \mathrm{mesh})$ prior to analysis.

\subsubsection{Stream sediments}

Two study areas, Chemeheuvi Valley and Chuckwalla Bench, contained major wash systems. For these two areas, stream-sediment samples were collected (Table 1) to supplement the chemical data from soil samples. Samples were active sediment that was composited from material collected from three or more locations within $\sim 10-\mathrm{m}$ radius of the center of a given sampling site. Samples were mostly collected from the upper $20 \mathrm{~cm}$ of

Table 1

Number and types of samples collected in and near six study areas, southeastern California, USA

\begin{tabular}{|c|c|c|c|c|}
\hline Study area & Soil & Sediment & Non-ashed plants & Ashed plants \\
\hline Western Mojave-Southern Section & 34 & & 34 & \\
\hline Western Mojave-Northern Section & 51 & & 107 & \\
\hline Goldstone & 48 & & 109 & \\
\hline Goffs & 50 & & 35 & 43 \\
\hline Chemehuevi Valley & 41 & 22 & & 15 \\
\hline Chuckwalla Bench & 5 & 14 & 14 & \\
\hline Other areas & 27 & - & $\underline{9}$ & - \\
\hline Regional totals & 256 & 36 & $\overline{308}$ & 58 \\
\hline
\end{tabular}

Samples listed as "Other areas" were collected in these US Geological Survey $7 \frac{1}{2}$ quadrangles in California: Soils: Barstow SE (3), Bitter Springs (4), East of Red Canyon (3), Hayfield Spring (11), Indian Cove (2), Ivanpah (2), and Nebo (2); Plants: Hayfield Spring (5), Red Canyon (4). 
Table 2

Summary statistics for 256 soil samples in regional data set, southeastern California, USA

\begin{tabular}{|c|c|c|c|c|c|c|c|}
\hline \multirow[t]{2}{*}{ Element } & \multicolumn{2}{|c|}{ Concentration range } & \multirow{2}{*}{$\begin{array}{l}\text { Number } \\
\text { unqualified }\end{array}$} & \multirow{2}{*}{$\begin{array}{l}\text { Percent } \\
\text { unqualified }\end{array}$} & \multirow{2}{*}{$\begin{array}{l}\text { Geometric } \\
\text { mean }\end{array}$} & \multirow{2}{*}{$\begin{array}{l}\text { Continental } \\
\text { crust }^{\mathrm{a}}\end{array}$} & \multirow{2}{*}{$\begin{array}{l}\text { Enrichment } \\
\text { value }\end{array}$} \\
\hline & Minimum & Maximum & & & & & \\
\hline $\mathrm{Al}(\%)$ & 4.39 & 10.42 & 256 & 100 & 7.45 & 8.04 & 0.93 \\
\hline As & 2.0 & 510 & 256 & 100 & 7.5 & 1.5 & 5.0 \\
\hline $\mathrm{Au}(\mathrm{ppb})$ & $\mathrm{N}(0.10)^{\mathrm{b}}$ & 680 & 88 & 34 & 0.68 & 1.8 & 0.38 \\
\hline $\mathrm{Ba}$ & 480 & 1100 & 256 & 100 & 740 & 550 & 1.4 \\
\hline $\mathrm{Be}$ & 1.0 & 3.0 & $200^{\mathrm{b}}$ & $100^{\mathrm{c}}$ & 2.1 & 3.0 & 0.70 \\
\hline $\mathrm{Ca}(\%)$ & 1.12 & 12.00 & 256 & 100 & 2.65 & 3.00 & 0.88 \\
\hline $\mathrm{Cd}$ & $\mathrm{N}(0.05)$ & 0.55 & $196^{\mathrm{b}}$ & $98^{\mathrm{c}}$ & 0.15 & 0.10 & 1.5 \\
\hline $\mathrm{Ce}$ & 44 & 210 & 256 & 100 & 100 & 64 & 1.6 \\
\hline $\mathrm{Co}$ & 5 & 22 & 256 & 100 & 10 & 10 & 1.0 \\
\hline $\mathrm{Cr}$ & 9 & 170 & 256 & 100 & 35 & 35 & 1.0 \\
\hline $\mathrm{Cs}$ & $\mathrm{N}(1.0)$ & 10 & $55^{\mathrm{b}}$ & $99^{\mathrm{c}}$ & 3.9 & 3.7 & 1.1 \\
\hline $\mathrm{Cu}$ & 8 & 61 & $220^{\mathrm{b}}$ & $100^{\mathrm{c}}$ & 19 & 25 & 0.76 \\
\hline $\mathrm{Eu}$ & $\mathrm{N}(2.0)$ & 5.0 & 80 & 31 & 3.0 & 0.88 & 3.4 \\
\hline $\mathrm{Fe}(\%)$ & 2.31 & 5.95 & 256 & 100 & 3.82 & 3.50 & 1.1 \\
\hline $\mathrm{Ga}$ & 7 & 40 & $200^{\mathrm{b}}$ & $100^{\mathrm{c}}$ & 19 & 17 & 1.1 \\
\hline $\mathrm{Hf}$ & 6 & 20 & $56^{\mathrm{b}}$ & $100^{\mathrm{c}}$ & 11 & 5.8 & 1.9 \\
\hline $\mathrm{Hg}$ & $\mathrm{N}(0.02)$ & 0.33 & $105^{\mathrm{b}}$ & $63^{\mathrm{c}}$ & 0.04 & 0.04 & 1.0 \\
\hline K (\%) & 1.65 & 3.14 & 256 & 100 & 2.20 & 2.80 & 0.79 \\
\hline $\mathrm{La}$ & 27 & 120 & 256 & 100 & 53 & 30 & 1.8 \\
\hline $\mathrm{Li}$ & 16 & 65 & $200^{\mathrm{b}}$ & $100^{\mathrm{c}}$ & 29 & 20 & 1.5 \\
\hline $\mathrm{Lu}$ & 0.31 & 1.1 & $56^{\mathrm{b}}$ & $100^{\mathrm{c}}$ & 0.46 & 0.32 & 1.4 \\
\hline $\operatorname{Mg}(\%)$ & 0.51 & 2.31 & 256 & 100 & 1.10 & 1.33 & 0.83 \\
\hline $\mathrm{Mn}$ & 430 & 3400 & 256 & 100 & 680 & 600 & 1.1 \\
\hline Mo & $\mathrm{N}(1.0)^{\mathrm{b}}$ & 30 & $164^{\mathrm{b}}$ & $64^{\mathrm{c}}$ & 3.4 & 1.5 & 2.7 \\
\hline $\mathrm{Na}(\%)$ & 0.74 & 3.17 & 256 & 100 & 1.90 & 2.89 & 0.66 \\
\hline $\mathrm{Nb}$ & 5 & 190 & $200^{\mathrm{b}}$ & $100^{\mathrm{c}}$ & 26 & 25 & 1.0 \\
\hline $\mathrm{Nd}$ & 19 & 99 & 256 & 100 & 45 & 26 & 1.7 \\
\hline $\mathrm{Ni}$ & 9 & 160 & $220^{\mathrm{b}}$ & $100^{\mathrm{c}}$ & 20 & 20 & 1.0 \\
\hline P (\%) & 0.03 & 0.25 & 256 & 100 & 0.09 & 0.07 & 1.3 \\
\hline $\mathrm{Pb}$ & $\mathrm{N}(4.0)$ & 51 & $206^{\mathrm{b}}$ & $94^{\mathrm{c}}$ & 17 & 20 & 0.85 \\
\hline $\mathrm{Rb}$ & 29 & 160 & $56^{\mathrm{b}}$ & $100^{\mathrm{c}}$ & 89 & 112 & 0.79 \\
\hline $\mathrm{Sb}$ & $\mathrm{N}(1.0)$ & 43 & 95 & 37 & 2.9 & 0.2 & 15.0 \\
\hline $\mathrm{Sc}$ & 7.0 & 20 & 256 & 100 & 12 & 11 & 1.1 \\
\hline $\mathrm{Sm}$ & 4.8 & 15 & $56^{\mathrm{b}}$ & $100^{\mathrm{c}}$ & 6.7 & 4.5 & 1.5 \\
\hline $\mathrm{Sr}$ & 170 & 900 & $220^{\mathrm{b}}$ & $100^{\mathrm{c}}$ & 340 & 350 & 0.97 \\
\hline $\mathrm{Ta}$ & $\mathrm{N}(0.5)$ & 4.7 & $28^{\mathrm{b}}$ & $50^{\mathrm{c}}$ & 1.4 & 2.2 & 0.64 \\
\hline $\mathrm{Tb}$ & $\mathrm{N}(0.2)$ & 1.9 & $7^{\mathrm{b}}$ & $14^{\mathrm{c}}$ & - & 0.64 & - \\
\hline Th & $\mathrm{N}(6.0)$ & 54 & 254 & 99 & 17 & 11 & 1.6 \\
\hline $\mathrm{Ti}(\%)$ & 0.28 & 1.0 & 256 & 100 & 0.55 & 0.30 & 1.8 \\
\hline $\mathrm{U}$ & 2.3 & 33 & $56^{\mathrm{b}}$ & $100^{\mathrm{c}}$ & 4.2 & 2.8 & 1.5 \\
\hline V & 54 & 170 & 256 & 100 & 94 & 60 & 1.6 \\
\hline W & $\mathrm{N}(1.0)$ & 160 & $23^{\mathrm{b}}$ & $41^{\mathrm{c}}$ & 7.2 & 2.0 & 3.6 \\
\hline $\mathrm{Y}$ & 13 & 75 & $220^{\mathrm{b}}$ & $100^{\mathrm{c}}$ & 28 & 22 & 1.3 \\
\hline $\mathrm{Yb}$ & 1.0 & 6.8 & 256 & 100 & 2.9 & 2.2 & 1.3 \\
\hline $\mathrm{Zn}$ & 48 & 180 & 256 & 100 & 78 & 71 & 1.1 \\
\hline
\end{tabular}

Concentrations are in parts per million (ppm), unless "(\%)" or "ppb" (parts per billion) shown after element symbol. $\mathrm{N}=$ not detected at the lower limit of determination shown in parentheses. Mean values based on unqualified analyses only. "-." indicates no meaningful value.

${ }^{\mathrm{a}}$ Concentration for Hg from Wedepohl (1995). All other concentrations from Taylor and McLennan (1995).

${ }^{b}$ Element has more than one lower limit of determination. Lowest value shown.

${ }^{\mathrm{c}}$ Element not determined for all samples. Percent based on actual number of samples analysed. 
the active sediment layer from areas where sediment was poorly sorted. Samples were prepared for analysis using the same procedures described above for soil samples.

\subsubsection{Plants}

We collected plants in spring (April-May), which is the peak blooming period for most annual and herbaceous perennial species (Jennings, 2001). We selected annual or perennial species known or suspected to be consumed by tortoises (Appendix 1; Burge and Bradley, 1976; Jennings, 1993, 2002; Oftedal, 2002; Van Devender et al., 2002). Only the aboveground parts of the plants were collected. We did not sort the plant parts by structure and function, but included stems, leaves, flowers, and fruits in the sample. In most cases, a given plant sample was composed of many different individuals from an area within $100 \mathrm{~m}$ of where soil and sediment samples were collected. A total of 366 plant samples, including 308 that were analysed without ashing and 58 that were ashed before analysis, were collected (Tables 1, 3 and 4). They comprised 35 different taxa in six different categories: (1) herbaceous annual or perennial forbs; (2) perennial grasses; (3) alien annual plants; (4) cacti; (5) weedy native species; and (6) a perennial shrub (Appendix 1). Plant nomenclature follows Hickman (1993). Samples were air-dried and not washed, thereby retaining any airborne contaminant particles or solid material transferred to the plant surface by wind or rain splatter. Thus, the plant samples reflected what tortoises were likely to be consuming. Dried material was macerated in a stainless-steel blender prior to analysis, and the resulting material for non-ashed samples was compressed into briquettes prior to analysis. Samples of dry material to be ashed were placed in a muffle furnace for about $24 \mathrm{~h}$ at temperatures not exceeding about $500{ }^{\circ} \mathrm{C}$.

\subsection{Sampling on traverses near roads and mining areas}

At the Goffs and Chemehuevi Valley Study Areas, many soil samples were collected along traverses perpendicular and adjacent to paved roads. Four traverses at Goffs, which included 39 soil samples, began $\sim 3 \mathrm{~m}$ west of the pavement edge and extended from 44 to $61 \mathrm{~m}$ westward. Two of the traverses in Chemehuevi Valley, which included 35 soil samples, began $\sim 4 \mathrm{~m}$ west of the pavement edge and extended about $95 \mathrm{~m}$ westward. An additional two traverses extended on both sides of US Highway 95 at distances from $\sim 4 \mathrm{~m}$ from the pavement edge to between 28 and $61 \mathrm{~m}$ east or west of the highway.

In the mining areas near Randsburg, Atolia, and Goldstone, some sampling was also done in traverses along paved and unpaved roads, beginning at the immediate sites of mining and extending outward, to help delineate the extent of contamination due to mining and mineralized rock.

\subsection{Analytical methods for soil, stream sediment, and plant samples}

Samples of all types were submitted to laboratories in random order in groups. Duplicate samples and internal standard samples were added to each group to monitor quality of the analyses. Of the 256 soil samples, 200 were analysed by XRAL Laboratories for 40 elements (Ag, Al, As, Au, Ba, Be, Bi, Ca, Cd, Ce, Co, Cr, Cu, Eu, Fe, Ga, Ho, K, La, Li, Mg, Mn, Mo, Na, Nb, Nd, Ni, P, Pb, Sc, Sn, Sr, Ta, Th, Ti, U, V, Y, Yb, Zn) using a total-digestion, inductively coupled plasma atomic-emission spectroscopy (ICP-AES) technique similar to that of Briggs (1996) and for 10 elements (Ag, As, $\mathrm{Au}, \mathrm{Bi}, \mathrm{Cd}, \mathrm{Cu}, \mathrm{Mo}$, 
Table 3

Summary statistics for 308 non-ashed plant samples in regional data set, southeastern California, USA

\begin{tabular}{|c|c|c|c|c|c|c|}
\hline \multirow[t]{2}{*}{ Element } & \multicolumn{2}{|c|}{ Concentration range } & \multirow{2}{*}{$\begin{array}{l}\text { Number } \\
\text { unqualified }\end{array}$} & \multirow{2}{*}{$\begin{array}{l}\text { Percent } \\
\text { unqualified }\end{array}$} & \multirow{2}{*}{$\begin{array}{l}\text { Geometric } \\
\text { mean }\end{array}$} & \multirow{2}{*}{$\begin{array}{l}\text { Enrichment } \\
\text { value }\end{array}$} \\
\hline & Minimum & Maximum & & & & \\
\hline As & $\mathrm{N}(0.01)^{\mathrm{a}}$ & 21 & 297 & 96 & 0.61 & 0.81 \\
\hline $\mathrm{Au}(\mathrm{ppb})$ & $\mathrm{N}(0.10)^{\mathrm{a}}$ & 140 & 262 & 85 & 2.5 & 37 \\
\hline $\mathrm{Ba}$ & $\mathrm{N}(5.0)$ & 180 & 303 & 98 & 44 & 0.59 \\
\hline $\mathrm{Br}$ & 0.8 & 230 & 308 & 100 & 25 & - \\
\hline $\mathrm{Ca}(\%)$ & 0.31 & 8.60 & 308 & 100 & 1.79 & 6.8 \\
\hline $\mathrm{Cd}$ & $\mathrm{N}(0.10)^{\mathrm{a}}$ & 5.2 & $195^{\mathrm{b}}$ & $98^{\mathrm{b}}$ & 0.97 & 65 \\
\hline $\mathrm{Ce}$ & 0.07 & 7.9 & $109^{\mathrm{b}}$ & $100^{\mathrm{b}}$ & 0.84 & 0.084 \\
\hline Co & 0.10 & 4.2 & 308 & 100 & 0.47 & 0.47 \\
\hline $\mathrm{Cr}$ & $\mathrm{N}(0.10)^{\mathrm{a}}$ & 13 & 307 & 99 & 1.4 & 0.40 \\
\hline Cs & $\mathrm{N}(0.01)^{\mathrm{a}}$ & 0.55 & 216 & 70 & 0.079 & 0.20 \\
\hline $\mathrm{Eu}$ & $\mathrm{N}(0.05)$ & 0.15 & 24 & 8 & - & - \\
\hline $\mathrm{Fe}(\%)$ & 0.005 & 0.37 & 308 & 100 & 0.042 & 0.11 \\
\hline $\mathrm{Hf}$ & $\mathrm{N}(0.01)^{\mathrm{a}}$ & 1.3 & 265 & 86 & 0.13 & 0.12 \\
\hline $\mathrm{Hg}$ & $\mathrm{N}(0.05)$ & 0.14 & 7 & 2 & - & - \\
\hline $\mathrm{Ir}$ & $\mathrm{N}(0.5)$ & 0.5 & 1 & $<1$ & - & - \\
\hline $\mathrm{K}(\%)$ & 0.34 & 7.90 & 308 & 100 & 2.66 & 12 \\
\hline $\mathrm{La}$ & 0.06 & 4.3 & 308 & 100 & 0.54 & 0.10 \\
\hline $\mathrm{Lu}$ & $\mathrm{N}(0.001)^{\mathrm{a}}$ & 0.053 & $257^{\mathrm{b}}$ & $87^{\mathrm{b}}$ & 0.007 & 0.15 \\
\hline Mo & $\mathrm{N}(0.03)^{\mathrm{a}}$ & 16 & 296 & 96 & 0.80 & 2.4 \\
\hline $\mathrm{Na}(\%)$ & 0.007 & 0.78 & 308 & 100 & 0.050 & 0.26 \\
\hline $\mathrm{Nd}$ & $\mathrm{N}(0.30)^{\mathrm{a}}$ & 3.3 & 81 & 26 & 1.0 & 0.22 \\
\hline $\mathrm{Ni}$ & $\mathrm{N}(2.0)^{\mathrm{a}}$ & 13 & 16 & 5 & - & - \\
\hline $\mathrm{Rb}$ & $\mathrm{N}(1.0)^{\mathrm{a}}$ & 78 & $294^{\mathrm{b}}$ & $98^{\mathrm{b}}$ & 7.3 & 0.82 \\
\hline $\mathrm{Sb}$ & $\mathrm{N}(0.003)^{\mathrm{a}}$ & 1.8 & 297 & 96 & 0.050 & 0.17 \\
\hline $\mathrm{Sc}$ & 0.01 & 0.88 & 308 & 100 & 0.12 & 0.10 \\
\hline $\mathrm{Se}$ & $\mathrm{N}(0.10)^{\mathrm{a}}$ & 2.8 & 52 & 17 & 0.42 & - \\
\hline $\mathrm{Sm}$ & $\mathrm{N}(0.01)$ & 0.49 & 306 & 99 & 0.060 & 0.090 \\
\hline $\mathrm{Sr}$ & $\mathrm{N}(5.0)^{\mathrm{a}}$ & 1300 & 301 & 98 & 120 & 3.5 \\
\hline Та & $\mathrm{N}(0.05)$ & 0.22 & 26 & 8 & - & - \\
\hline Th & $\mathrm{N}(0.03)^{\mathrm{a}}$ & 1.8 & 227 & 74 & 0.17 & 0.10 \\
\hline $\mathrm{U}$ & $\mathrm{N}(0.003)^{\mathrm{a}}$ & 0.30 & 137 & 44 & 0.030 & 0.071 \\
\hline $\mathrm{W}$ & $\mathrm{N}(0.01)^{\mathrm{a}}$ & 3.7 & 181 & 59 & 0.22 & 0.31 \\
\hline $\mathrm{Yb}$ & $\mathrm{N}(0.001)^{\mathrm{a}}$ & 0.38 & 268 & 87 & 0.040 & 0.14 \\
\hline $\mathrm{Zn}$ & 3.0 & 69 & 308 & 100 & 15 & 1.9 \\
\hline
\end{tabular}

Concentrations are in dry weight and are in parts per million (ppm), unless "(\%)" or "ppb" (parts per billion) shown after element symbol. $\mathrm{N}=$ not detected at the lower limit of determination shown in parentheses. Mean values based on unqualified analyses only. "--" indicates no meaningful value.

${ }^{a}$ Element has more than one lower limit of determination. Lowest value shown.

${ }^{b}$ Element not determined for all samples. Percent based on actual number of samples analysed.

$\mathrm{Pb}, \mathrm{Sb}, \mathrm{Zn}$ ) using a partial-digestion ICP-AES technique similar to that of Motooka (1996). The remaining 56 samples were analysed by ActLabs-Skyline for as many as 29 elements (As, Au, Ba, Br, Ce, Co, Cr, Cs, Eu, Fe, Hf, Hg, Ir, La, Lu, Na, Nd, Rb, Sb, Sc, $\mathrm{Se}, \mathrm{Sm}, \mathrm{Sn}, \mathrm{Ta}, \mathrm{Tb}, \mathrm{Th}, \mathrm{U}, \mathrm{W}, \mathrm{Yb}$ ) using instrumental neutron-activation analysis (INAA) (ActLabs-Skyline, 2001) and for as many as 20 elements $(\mathrm{Ag}, \mathrm{Al}, \mathrm{Be}, \mathrm{Bi}, \mathrm{Ca}, \mathrm{Cd}, \mathrm{Cu}, \mathrm{K}$, $\mathrm{Mg}, \mathrm{Mn}, \mathrm{Mo}, \mathrm{Ni}, \mathrm{P}, \mathrm{Pb}, \mathrm{Ti}, \mathrm{S}, \mathrm{Sr}, \mathrm{V}, \mathrm{Y}, \mathrm{Zn}$ ) using a total-digestion ICP-AES technique 
Table 4

Summary statistics for 58 ashed plant samples in regional data set, southeastern California, USA

\begin{tabular}{|c|c|c|c|c|c|c|c|}
\hline \multirow[t]{2}{*}{ Element } & \multicolumn{2}{|c|}{ Concentration range } & \multirow{2}{*}{$\begin{array}{l}\text { Number } \\
\text { unqualified }\end{array}$} & \multirow{2}{*}{$\begin{array}{l}\text { Percent } \\
\text { unqualified }\end{array}$} & \multirow{2}{*}{$\begin{array}{l}\text { Geometric } \\
\text { mean }\end{array}$} & \multicolumn{2}{|c|}{ Enrichment values } \\
\hline & Minimum & Maximum & & & & Plant/soil & Plant/plant ${ }^{\mathrm{c}}$ \\
\hline $\mathrm{Ag}$ & $\mathrm{N}(0.02)^{\mathrm{a}}$ & 1.1 & 10 & 17 & - & - & - \\
\hline $\mathrm{Al}(\%)$ & 0.068 & 0.97 & $43^{\mathrm{b}}$ & $100^{\mathrm{b}}$ & 0.27 & 0.036 & - \\
\hline As & 0.5 & 6.3 & 58 & 100 & 2.5 & 0.33 & 0.41 \\
\hline B & 66 & 900 & 58 & 100 & 190 & - & - \\
\hline $\mathrm{Ba}$ & 130 & 3600 & 58 & 100 & 510 & 0.69 & 1.2 \\
\hline $\mathrm{Be}$ & 0.02 & 0.74 & 58 & 100 & 0.12 & 0.057 & - \\
\hline $\mathrm{Bi}$ & $\mathrm{N}(0.01)^{\mathrm{a}}$ & 0.22 & $13^{\mathrm{b}}$ & $76^{\mathrm{b}}$ & - & - & - \\
\hline $\mathrm{Br}$ & 29 & 300 & $43^{\mathrm{b}}$ & $100^{\mathrm{b}}$ & 86 & - & 0.34 \\
\hline $\mathrm{Ca}(\%)$ & 5.56 & 24 & $43^{\mathrm{b}}$ & $100^{\mathrm{b}}$ & 13 & 4.9 & 0.73 \\
\hline $\mathrm{Cd}$ & $\mathrm{N}(0.29)^{\mathrm{a}}$ & 3.4 & 51 & 88 & 1.1 & 7.3 & 0.11 \\
\hline $\mathrm{Ce}$ & 2.2 & 53 & 58 & 100 & 9.1 & 0.091 & 1.1 \\
\hline $\mathrm{Co}$ & 1.2 & 10 & 58 & 100 & 3.6 & 0.36 & 0.77 \\
\hline $\mathrm{Cr}$ & 1.8 & 29 & 58 & 100 & 10 & 0.29 & 0.71 \\
\hline Cs & 0.15 & 2.7 & 58 & 100 & 0.62 & 0.16 & 0.78 \\
\hline $\mathrm{Cu}$ & 22 & 1200 & 58 & 100 & 180 & 9.5 & - \\
\hline Dy & 0.094 & 2.6 & 58 & 100 & 0.45 & - & - \\
\hline $\mathrm{Er}$ & 0.048 & 1.3 & 58 & 100 & 0.25 & - & - \\
\hline $\mathrm{Eu}$ & 0.05 & 1.4 & 58 & 100 & 0.24 & 0.080 & - \\
\hline $\mathrm{Fe}(\%)$ & 0.16 & 1.7 & 58 & 100 & 0.75 & 0.20 & 1.8 \\
\hline $\mathrm{Ga}$ & 0.33 & 6.6 & 58 & 100 & 1.2 & 0.063 & - \\
\hline Gd & 0.16 & 4.5 & 58 & 100 & 0.85 & - & - \\
\hline $\mathrm{Ge}$ & 0.01 & 0.15 & 58 & 100 & 0.060 & - & - \\
\hline $\mathrm{Hf}$ & 0.01 & 0.30 & $54^{\mathrm{b}}$ & $100^{\mathrm{b}}$ & 0.030 & 0.0027 & 0.023 \\
\hline Но & 0.016 & 0.47 & 58 & 100 & 0.080 & - & - \\
\hline I & $\mathrm{N}(0.02)^{\mathrm{a}}$ & 1.2 & 41 & 71 & 0.15 & - & - \\
\hline In & $\mathrm{N}(0.005)^{\mathrm{a}}$ & 13 & 56 & 97 & 1.2 & - & - \\
\hline K (\%) & 9.48 & $>34$ & $4^{b}$ & $9^{b}$ & - & - & - \\
\hline $\mathrm{La}$ & 1.3 & 27 & 58 & 100 & 5.2 & 0.034 & 0.96 \\
\hline $\mathrm{Li}$ & 2.0 & 75 & 58 & 100 & 13 & 0.45 & - \\
\hline $\mathrm{Lu}$ & 0.005 & 0.14 & 58 & 100 & 0.030 & 0.065 & 0.43 \\
\hline $\operatorname{Mg}(\%)$ & 0.89 & 12 & 58 & 100 & 2.95 & 2.7 & - \\
\hline $\mathrm{Mn}$ & 290 & 3600 & 58 & 100 & 1200 & 1.8 & - \\
\hline Mo & 0.54 & 290 & 58 & 100 & 4.4 & 1.3 & 0.55 \\
\hline $\mathrm{Na}(\%)$ & $\mathrm{N}(0.01)$ & 0.60 & 56 & 97 & 0.13 & 0.068 & 0.26 \\
\hline $\mathrm{Nb}$ & 0.05 & 0.48 & 58 & 100 & 0.14 & 0.0054 & - \\
\hline $\mathrm{Nd}$ & 0.88 & 24 & 58 & 100 & 3.8 & 0.084 & 0.38 \\
\hline $\mathrm{Ni}$ & 3.8 & 30 & 58 & 100 & 13 & 0.65 & - \\
\hline $\mathrm{Pb}$ & 0.88 & 33 & 58 & 100 & 4.7 & 0.28 & - \\
\hline $\operatorname{Pr}$ & 0.26 & 6.4 & 58 & 100 & 1.1 & - & - \\
\hline $\mathrm{Rb}$ & 11 & 68 & 58 & 100 & 33 & 0.37 & 0.45 \\
\hline $\mathrm{Re}$ & 0.004 & 1900 & 58 & 100 & 15 & - & - \\
\hline $\mathrm{Sb}$ & $\mathrm{N}(0.01)^{\mathrm{a}}$ & 0.11 & 26 & 63 & 0.030 & 0.010 & 0.060 \\
\hline $\mathrm{Sc}$ & 0.40 & 2.4 & $43^{\mathrm{b}}$ & $100^{\mathrm{b}}$ & 1.0 & 1.1 & 0.83 \\
\hline $\mathrm{Se}$ & 0.46 & 3.1 & 58 & 100 & 1.3 & - & 0.31 \\
\hline $\mathrm{Si}$ & 270 & 3300 & $43^{\mathrm{b}}$ & $100^{\mathrm{b}}$ & 1200 & - & - \\
\hline $\mathrm{Sm}$ & 0.15 & 4.6 & 58 & 100 & 0.74 & 0.11 & 1.2 \\
\hline $\mathrm{Sn}$ & $\mathrm{N}(1.0)$ & 1.4 & 14 & 24 & 1.2 & - & - \\
\hline $\mathrm{Sr}$ & 550 & 3700 & 58 & 100 & 1400 & 4.1 & 1.2 \\
\hline $\mathrm{Ta}$ & $\mathrm{N}(0.01)$ & 0.01 & $15^{\mathrm{b}}$ & $50^{\mathrm{b}}$ & 0.010 & 0.0071 & - \\
\hline
\end{tabular}


Table 4 (continued)

\begin{tabular}{|c|c|c|c|c|c|c|c|}
\hline \multirow[t]{2}{*}{ Element } & \multicolumn{2}{|c|}{ Concentration range } & \multirow{2}{*}{$\begin{array}{l}\text { Number } \\
\text { unqualified }\end{array}$} & \multirow{2}{*}{$\begin{array}{l}\text { Percent } \\
\text { unqualified }\end{array}$} & \multirow{2}{*}{$\begin{array}{l}\text { Geometric } \\
\text { mean }\end{array}$} & \multicolumn{2}{|c|}{ Enrichment values } \\
\hline & Minimum & Maximum & & & & Plant/soil & Plant/plant ${ }^{\mathrm{c}}$ \\
\hline $\mathrm{Tb}$ & 0.02 & 0.56 & 58 & 100 & 0.10 & - & - \\
\hline $\mathrm{Te}$ & $\mathrm{N}(0.01)^{\mathrm{a}}$ & 0.19 & $48^{b}$ & $84^{\mathrm{b}}$ & 0.060 & - & - \\
\hline $\mathrm{Th}$ & 0.12 & 15 & 58 & 100 & 1.0 & 0.059 & 0.59 \\
\hline $\mathrm{Ti}(\%)$ & 0.0078 & 0.070 & 58 & 100 & 0.029 & 0.053 & - \\
\hline $\mathrm{Tl}$ & 0.02 & 0.41 & 58 & 100 & 0.13 & - & - \\
\hline $\mathrm{Tm}$ & 0.005 & 0.16 & 58 & 100 & 0.030 & - & - \\
\hline $\mathrm{U}$ & 0.03 & 1.7 & 58 & 100 & 0.17 & 0.040 & 0.57 \\
\hline $\mathrm{V}$ & 0.8 & 41 & 58 & 100 & 5.3 & 0.056 & - \\
\hline $\mathrm{W}$ & $\mathrm{N}(0.10)$ & 0.90 & 24 & 56 & 0.33 & 0.046 & 0.15 \\
\hline $\mathrm{Y}$ & 0.54 & 14 & 58 & 100 & 2.7 & 0.096 & - \\
\hline $\mathrm{Yb}$ & 0.034 & 1.0 & 58 & 100 & 0.18 & 0.062 & 0.45 \\
\hline $\mathrm{Zn}$ & 35 & 490 & 58 & 100 & 120 & 1.5 & 0.80 \\
\hline $\mathrm{Zr}$ & 0.02 & 9.7 & $52^{\mathrm{b}}$ & $100^{\mathrm{b}}$ & 0.38 & - & - \\
\hline Ash $(\%)$ & 4.80 & 20.8 & $51^{b}$ & $100^{\mathrm{b}}$ & 9.71 & - & - \\
\hline
\end{tabular}

Concentrations are in ashed weight and are in parts per million (ppm), unless "(\%)" shown after element symbol. $\mathrm{N}=$ not detected at the lower limit of determination shown in parentheses. Mean values based on unqualified analyses only. "_-" indicates no meaningful value.

${ }^{a}$ Element has more than one lower limit of determination; lowest value shown.

${ }^{b}$ Not all elements determined for all samples; number of unqualified samples is total number of samples analysed.

${ }^{\mathrm{c}}$ Ratio is geometric mean value for plant ash divided by mean value for dry weight plant multiplied by 10 .

(ActLabs-Skyline, 2001). In addition, $\mathrm{Hg}$ was determined by XRAL Laboratories on 168 samples using a cold-vapor atomic absorption technique similar to that of O'Leary et al. (1996). Examination of initial soil analytical data sets from the two laboratories indicated that some elements either were: (1) highly censored ( $<7$ values above the respective lower limits of determination); or (2) duplicated by more than one analytical method. All but one set of duplicated elements ( $\mathrm{As}, \mathrm{Au}, \mathrm{Cd}, \mathrm{Cu}, \mathrm{Mo}, \mathrm{Pb}, \mathrm{Zn}$ ) and all highly censored elements (Ag, Bi, Br, Ho, Ir, S, Se, Sn) were deleted from the data sets and not further evaluated.

Because the soils were analysed by two different laboratories, two separate data sets (200 samples and 56 samples, respectively) were initially compiled for undeleted elements to compare results of the two laboratories. Most chemical data for elements in media such as soil are distributed log-normally. Geometric mean values are thus considered to represent the best measure of central tendency for such distributions, and as such are deemed the best values to use to identify overall differences in element concentrations in different media and localities. Therefore, we used geometric mean values for those elements determined by both laboratories to compare similarities and differences between the two data sets. Additionally, sources of samples in the two data sets were examined to detect any biases in chemistry that could result from an unusual number of samples in one data set being from areas contaminated by past mining or other anthropogenic activities. As a result of the comparisons, we determined that the overall differences between 24 elements in the two data sets (Al, As, Au, Ba, Ca, Ce, Co, Cr, Eu, Fe, K, La, Mg, Mn, Na, Nd, P, $\mathrm{Sb}, \mathrm{Sc}, \mathrm{Th}, \mathrm{Ti}, \mathrm{V}, \mathrm{Yb}, \mathrm{Zn}$ ), as measured by geometric means, did not exceed $\pm 20 \%$, an acceptable difference for purposes of this study. Thus, these 24 elements were merged. 
An additional 21 elements (Be, Cd, Cs, Cu, Ga, Hf, $\mathrm{Hg}, \mathrm{Li}, \mathrm{Lu}, \mathrm{Mo}, \mathrm{Nb}, \mathrm{Ni}, \mathrm{Pb}, \mathrm{Rb}, \mathrm{Sm}$, $\mathrm{Sr}, \mathrm{Ta}, \mathrm{Tb}, \mathrm{U}, \mathrm{W}, \mathrm{Y}$ ) were, in nearly every case, only determined in one data set or the other (Footnote b, Table 2), but had sufficient analyses to include in the final soil data set. The resulting data set with 45 elements was used in the discussions that follow.

A total of 48 elements was determined in the stream-sediment samples by ActLabsSkyline (2001). Twenty-nine elements (same list as analysed by ActLabs-Skyline for soils) were determined using INAA, and 19 elements $(\mathrm{Ag}, \mathrm{Al}, \mathrm{Be}, \mathrm{Bi}, \mathrm{Ca}, \mathrm{Cd}, \mathrm{Cu}, \mathrm{K}, \mathrm{Mg}, \mathrm{Mn}$, Mo, Ni, P, Pb, Sr, Ti, V, Y, Zn) by inductively coupled plasma optical-emission spectroscopy (ICP-OES). Examination of the initial analytical data set indicated that seven elements (Ag, Bi, Br, Hg, Ir, Se, Sn) contained no values or only one reported value above the respective lower limits of determination for each element (a highly censored element). These seven elements were deleted from the data set and not further evaluated.

All plant samples were analysed by ActLabs-Skyline (2001). The 308 unashed, dried samples (Table 1) were analysed for as many as 35 elements (Ag, As, Ba, Br, Ca, Cd, Ce, $\mathrm{Co}, \mathrm{Cr}, \mathrm{Cs}, \mathrm{Eu}, \mathrm{Fe}, \mathrm{Hf}, \mathrm{Hg}$, Ir, K, La, Lu, Mo, Na, Nd, Ni, Rb, Sb, Sc, Se, Sm, Sr, Ta, Tb, $\mathrm{Th}, \mathrm{U}, \mathrm{W}, \mathrm{Yb}, \mathrm{Zn}$ ) by an INAA technique. The 58 ashed samples (Table 1) were analysed for as many as 62 elements (Ag, Al, As, B, Ba, Be, Bi, Br, Ca, Cd, Ce, Co, Cr, Cs, Cu, Dy, $\mathrm{Er}, \mathrm{Eu}, \mathrm{Fe}, \mathrm{Ga}, \mathrm{Gd}$, Ge, Hf, Ho, I, In, K, La, Li, Lu, Mg, Mn, Mo, Na, Nb, Nd, Ni, Pb, Pr, Rb, Re, Sb, Sc, Se, Si, Sm, Sn, Sr, Ta, Tb, Te, Th, Ti, Tl, Tm, U, V, W, Y, Yb, Zn, Zr), using inductively coupled plasma mass spectrometry (ICP-MS). For the same reasons given for soil and sediment samples, some elements in the master data sets for non-ashed and ashed plants from individual study areas were deleted and not further evaluated.

\subsection{Methods for data presentation and evaluation}

The term "enrichment" in this paper is used to describe the ratio of a given chemical concentration to some reference concentration, where the resulting ratio has a value of $>1.0$. For purposes of discussion in the text and Table 20, we define a "strong" or "significant" enrichment of a given element as one with a value $>2$ times $(>2 \times)$ a reference concentration unless otherwise indicated. The terms "weakly" or "slightly" enriched refer to an enrichment ratio between $1.2 \times$ and $1.9 \times$, unless otherwise indicated.

In the accompanying tables, unqualified analyses for a given element are those reported by the analyst as being of a concentration greater than the lower limit of determination for that element. Samples analysed, but reported by the analyst as being below the lower limit of determination are called qualified analyses.

The analytical data given for $\mathrm{Au}$ in plants in the accompanying tables and discussions are generally based on analyses determined using a relatively small sample. As a result, these data are not truly quantitative, but are included anyway to provide some context to the other elements associated with Au-rich mineral deposits in the region.

To evaluate the potential role of anthropogenic sources of contamination to the natural environment, we plotted element distributions on base maps for each study area. We then examined element anomalies: (1) adjacent to and at varying distances from paved roads at two study areas; (2) associated with mining districts at two study areas; and (3) where military maneuvers have occurred historically at three study areas. We emphasized the data for As, a potentially toxic element, because it seems to be present in anomalous concentrations in many of the localities we sampled. 
For each study area, samples with concentrations greater than about two times the local (or sometimes regional) geometric mean value for each element were evaluated to determine their locations and the possible source(s) of these highest concentrations.

\section{Results: chemical differences by area}

\subsection{Summaries of chemical analyses for regional data}

Summaries of analyses for soils and plants for the entire region are given in Tables 2-4. Minimum and maximum values and geometric mean values give estimates of the ranges of concentrations and typical abundance concentrations for selected elements in soils and plants, respectively. Geometric mean values for elements in a given sample medium in each study area were compared to those in other media from the same area and to those for the same medium in the region as a whole to determine which elements are anomalous in each medium and in each study area.

The ratios of geometric mean values for elements determined in soils to crustal abundance values from the literature for rock samples are shown in the "Enrichment value" column (Table 2$)$. These values show that soils are significantly enriched $(>2 \times$ the geometric mean for rocks) region-wide only in $\mathrm{As}, \mathrm{Eu}, \mathrm{Mo}, \mathrm{Sb}$, and W. For Eu, Mo, Sb, and $\mathrm{W}$, actual mean values in soils would be closer to crustal abundance values if censored data could be included in calculating mean values. In some cases, the use of the median (50th percentile) value for a highly censored element, instead of the geometric mean value, may give a better estimate of the most typical value. A calculation of enrichment values using median values for these 4 elements $(\mathrm{Eu},<2$; Mo, 3.0; Sb, <1.0; W, <1.0) instead of geometric mean values suggests that of the 4 elements, only $\mathrm{Sb}$ (median-based enrichment value, <5.0) and possibly Eu (value, <2.3) have geometric mean-based enrichment values that are probably $>2$. Thus data in Table 2 suggest that only As, as well as chemically associated $\mathrm{Sb}$ and possibly $\mathrm{Eu}$, are generally anomalous region-wide. Elements commonly found in weather-resistant minerals, such as $\mathrm{Ba}, \mathrm{Ce}, \mathrm{Hf}, \mathrm{La}, \mathrm{Li}, \mathrm{Lu}, \mathrm{Nd}, \mathrm{P}, \mathrm{Sm}, \mathrm{Th}, \mathrm{Ti}, \mathrm{U}$, $\mathrm{V}, \mathrm{Y}$, and $\mathrm{Yb}$, are also slightly enriched $(1.2 \times-1.9 \times)$ region-wide, probably as a result of weathering processes that leach less resistant minerals from soils. Mean values for several elements (Al, $\mathrm{Ca}, \mathrm{K}, \mathrm{Mg}, \mathrm{Na}, \mathrm{Rb}, \mathrm{Sr}$ ) commonly related to major rock-forming minerals, such as feldspars, as well as the value for Au are generally lower than their established crustal values in rock samples. The mean value for Au however, is based on a relatively limited number of analyses above the lower limit of determination (Table 2). The six other elements are relatively more mobile when released by the chemical breakdown of feldspars and other rock-forming minerals, so that these elements are more readily leached from soils as compared to their fresher parent source rocks.

The best comparisons between soil or sediment analyses and plant analyses are done using ashed plant material. Ashing of plants removes all organic material. The remaining material is inorganic and roughly equivalent to the material in desert soils or sediments. However, most plants were analysed as non-ashed, dried material to determine some elements that may be volatilized from plant material during ashing. To compare the nonashed sample data (Table 3) with that of ashed samples (Table 4), we estimated equivalent concentrations in non-ashed samples by examining elements in samples run by both methods, as well as by using calculated percent ash where available. Our limited analyses (58 samples, Table 4 ) indicate that the ash content in plant samples varies from $\sim 4.80 \%$ to 
20.8\% (arithmetic mean, 9.51\%; geometric mean, 9.71\%). Ash contents vary somewhat from species to species. For this project we rounded off the mean value of $9.71 \%$ to $10 \%$ as a best approximation of average percent ash. Thus, concentrations in non-ashed material were multiplied by a factor of 10 to estimate roughly equivalent ashed concentrations. Inasmuch as some elements may be volatilized when a sample is ashed, our estimates for all elements cannot be considered quantitative.

For all plant samples, comparisons of non-ashed mean values (Table 3) multiplied by 10, with ashed mean values, where both are present, (Table 4) indicate that most elements determined in both media have similar or lower concentrations in ashed samples, as indicated by enrichment values (Plant/plant column, Table 4). Many of the lower enrichment values in this column are for elements such as $\mathrm{As}, \mathrm{Br}, \mathrm{Cd}, \mathrm{Sb}$, and $\mathrm{Se}$, and these values are a result of partial volatilization of the elements during ashing (Table 4).

Enrichment values based on comparisons of mean values for non-ashed plants (Table 3) multiplied by 10 to those of soils (Table 2 ) show values of $1.9 \times-65 \times$ for $\mathrm{Ca}, \mathrm{Cd}, \mathrm{K}, \mathrm{Mo}$, $\mathrm{Sr}, \mathrm{Zn}$ and possibly $\mathrm{Au}$ (Table 3). As compared to soils, the ashed plants are enriched $(>1.2 \times)$ in $\mathrm{Ca}, \mathrm{Cd}, \mathrm{Cu}, \mathrm{Mg}, \mathrm{Mn}, \mathrm{Mo}, \mathrm{Sr}$, and $\mathrm{Zn}$ (Plant/soil column, Table 4). With the exceptions of $\mathrm{Au}, \mathrm{Cd}$, and $\mathrm{Cu}$, all of these elements are known to be essential for plant metabolism (Speidel and Agnew, 1982). No other elements determined show a similar regional enrichment in plant material.

\subsection{Summaries of chemical analyses for six study areas}

\subsubsection{Western Mojave Study Area-Southern Section}

Soils: Geometric mean values for elements analysed in soil samples collected in the Southern Section were compared to those in the regional data set (Tables 2 and 5). For those elements determined in both data sets, enrichment values based on means suggest that samples of soil collected in the Southern Section are slightly enriched $(1.2 \times-2.0 \times)$ overall in the elements As, Hf, La, Li, Lu, Mo, Nb, Rb, Sm, Ta, Th, and U (Table 5). With the exception of As all of these elements are commonly naturally enriched in the dominant granitic rocks of this study area as compared to many other rock types. The slight enrichment of As $(1.2 \times)$ may be natural or a result of As dispersion from areas of mining farther north, as discussed below.

Plants: Sixteen species (Achy, Amte, Asdi, Asla, Asle, Cabo, Chbr, Chwm, Erci, Lohu, Ment, Mibi, Mica, Phta, Scsp, Stmi; see Appendix 1) were analysed. For elements found in both data sets, the geometric mean values (dry weight) for those in Southern Section plants (Table 6) generally contain lower concentrations than those in plants collected for the entire region (Table 3), as shown in the "Plant/plant enrichment values" column (Table 6). A comparison of geometric mean values for dry weight data for the 34 plant samples (multiplied by a factor of 10) with those of local soils (Table 5) indicates that, for elements common to both data sets, plant material is particularly enriched $(1.6 \times-100 \times)$ in five elements (Ca, K, Sr, Zn, and possibly Au) (Plant/soil column, Table 6). Concentrations of all other elements are relatively much lower in the plants than in the local soils.

\subsubsection{Western Mojave Study Area-Northern Section}

Soils: Geometric mean values for elements analysed in soil samples collected in the Northern Section were compared to those in the regional data set of soils (Tables 2 and 7). For those elements determined in both data sets, the enrichment values (Table 7) suggest 
Table 5

Summary statistics for 34 soil samples, Western Mojave Study Area, Southern Section, southeastern California, USA

\begin{tabular}{|c|c|c|c|c|c|c|}
\hline \multirow[t]{2}{*}{ Element } & \multicolumn{2}{|c|}{ Concentration range } & \multirow{2}{*}{$\begin{array}{l}\text { Number } \\
\text { unqualified }\end{array}$} & \multirow{2}{*}{$\begin{array}{l}\text { Percent } \\
\text { unqualified }\end{array}$} & \multirow{2}{*}{$\begin{array}{l}\text { Geometric } \\
\text { mean }\end{array}$} & \multirow{2}{*}{$\begin{array}{l}\text { Enrichment } \\
\text { value }\end{array}$} \\
\hline & Minimum & Maximum & & & & \\
\hline $\mathrm{Al}(\%)$ & 6.98 & 9.45 & 34 & 100 & 8.49 & 1.1 \\
\hline As & 5.0 & 60 & 34 & 100 & 9.3 & 1.2 \\
\hline $\mathrm{Au}(\mathrm{ppb})$ & $\mathrm{N}(0.10)^{\mathrm{a}}$ & 28 & 12 & 35 & 0.25 & 0.37 \\
\hline $\mathrm{Ba}$ & 630 & 910 & 34 & 100 & 760 & 1.0 \\
\hline $\mathrm{Be}$ & 2.0 & 3.0 & $27^{\mathrm{b}}$ & $100^{\mathrm{b}}$ & 2.4 & 1.1 \\
\hline $\mathrm{Ca}(\%)$ & 1.12 & 9.70 & 34 & 100 & 2.17 & 0.82 \\
\hline $\mathrm{Cd}$ & $\mathrm{N}(0.05)$ & 0.24 & 26 & 96 & 0.13 & 0.87 \\
\hline $\mathrm{Ce}$ & 84 & 210 & 34 & 100 & 110 & 1.1 \\
\hline Co & 5 & 11 & 34 & 100 & 7.4 & 0.74 \\
\hline $\mathrm{Cr}$ & 9 & 78 & 34 & 100 & 20 & 0.57 \\
\hline $\mathrm{Cs}$ & $\mathrm{N}(1.0)$ & 6.0 & $6^{\mathrm{b}}$ & $86^{\mathrm{b}}$ & 3.8 & 0.97 \\
\hline $\mathrm{Cu}$ & 8 & 21 & 34 & 100 & 14 & 0.74 \\
\hline $\mathrm{Eu}$ & $\mathrm{N}(1.7)^{\mathrm{a}}$ & 4.9 & 9 & 26 & 2.1 & 0.70 \\
\hline $\mathrm{Fe}(\%)$ & 2.43 & 4.72 & 34 & 100 & 3.51 & 0.92 \\
\hline $\mathrm{Ga}$ & 10 & 31 & $27^{\mathrm{b}}$ & $100^{\mathrm{b}}$ & 18 & 0.95 \\
\hline $\mathrm{Hf}$ & 11 & 18 & $7^{\mathrm{b}}$ & $100^{\mathrm{b}}$ & 14 & 1.3 \\
\hline $\mathrm{Hg}$ & 0.03 & 0.33 & $27^{\mathrm{b}}$ & $100^{\mathrm{b}}$ & 0.040 & 1.0 \\
\hline K $(\%)$ & 1.70 & 2.55 & 34 & 100 & 2.31 & 1.1 \\
\hline $\mathrm{La}$ & 49 & 120 & 34 & 100 & 61 & 1.2 \\
\hline $\mathrm{Li}$ & 26 & 55 & $27^{\mathrm{b}}$ & $100^{\mathrm{b}}$ & 38 & 1.3 \\
\hline $\mathrm{Lu}$ & 0.49 & 1.1 & $7^{\mathrm{b}}$ & $100^{\mathrm{b}}$ & 0.64 & 1.4 \\
\hline $\operatorname{Mg}(\%)$ & 0.51 & 1.26 & 34 & 100 & 0.90 & 0.82 \\
\hline $\mathrm{Mn}$ & 450 & 890 & 34 & 100 & 640 & 0.94 \\
\hline Mo & $\mathrm{N}(2.0)$ & 30 & 10 & 29 & 6.2 & 1.8 \\
\hline $\mathrm{Na}(\%)$ & 1.56 & 2.72 & 34 & 100 & 2.15 & 1.1 \\
\hline $\mathrm{Nb}$ & 21 & 48 & $27^{\mathrm{b}}$ & $100^{\mathrm{b}}$ & 31 & 1.2 \\
\hline $\mathrm{Nd}$ & 31 & 97 & 34 & 100 & 47 & 1.0 \\
\hline $\mathrm{Ni}$ & 9 & 94 & 34 & 100 & 16 & 0.80 \\
\hline P (\%) & 0.049 & 0.25 & 34 & 100 & 0.090 & 1.0 \\
\hline $\mathrm{Pb}$ & 6.0 & 41 & 34 & 100 & 19 & 1.1 \\
\hline $\mathrm{Rb}$ & 61 & 160 & $7^{\mathrm{b}}$ & $100^{\mathrm{b}}$ & 110 & 1.2 \\
\hline $\mathrm{Sb}$ & $\mathrm{N}(1.0)$ & 7.0 & 23 & 68 & 1.8 & 0.62 \\
\hline $\mathrm{Sc}$ & 7.0 & 16 & 34 & 100 & 9.4 & 0.78 \\
\hline $\mathrm{Sm}$ & 6.3 & 15 & $7^{b}$ & $100^{\mathrm{b}}$ & 8.8 & 1.3 \\
\hline $\mathrm{Sr}$ & 170 & 400 & 34 & 100 & 310 & 0.91 \\
\hline $\mathrm{Ta}$ & $\mathrm{N}(0.5)$ & 4.7 & $4^{\mathrm{b}}$ & $57^{\mathrm{b}}$ & 2.8 & 2.0 \\
\hline Th & 12 & 54 & 34 & 100 & 23 & 1.4 \\
\hline $\operatorname{Ti}(\%)$ & 0.28 & 0.77 & 34 & 100 & 0.49 & 0.89 \\
\hline $\mathrm{U}$ & 4.2 & 33 & $7^{b}$ & $100^{\mathrm{b}}$ & 7.5 & 1.8 \\
\hline V & 60 & 130 & 34 & 100 & 78 & 0.83 \\
\hline W & $\mathrm{N}(1.0)$ & 2.0 & $1^{\mathrm{b}}$ & $14^{\mathrm{b}}$ & - & - \\
\hline Y & 18 & 37 & 34 & 100 & 23 & 0.82 \\
\hline $\mathrm{Yb}$ & 2.0 & 6.8 & 34 & 100 & 2.4 & 0.83 \\
\hline $\mathrm{Zn}$ & 49 & 130 & 34 & 100 & 79 & 1.0 \\
\hline
\end{tabular}

Concentrations are in parts per million (ppm), unless "(\%)" or "ppb" (parts per billion) shown after element symbol. $\mathrm{N}=$ not detected at the lower limit of determination shown in parentheses. Mean values based on unqualified analyses only. "-_" indicates no meaningful value. Bolded maximum concentrations indicate those elements with highest ratio of maximum concentration to geometric mean value.

${ }^{a}$ Element has more than one lower limit of determination. Lowest value shown.

${ }^{\mathrm{b}}$ Element not determined for all samples. Percent based on number of samples analysed. 
Table 6

Summary statistics for 34 non-ashed plant samples, Western Mojave Study Area, Southern Section, southeastern California, USA

\begin{tabular}{|c|c|c|c|c|c|c|c|}
\hline \multirow[t]{2}{*}{ Element } & \multicolumn{2}{|c|}{ Concentration range } & \multirow{2}{*}{$\begin{array}{l}\text { Number } \\
\text { unqualified }\end{array}$} & \multirow{2}{*}{$\begin{array}{l}\text { Percent } \\
\text { unqualified }\end{array}$} & \multirow{2}{*}{$\begin{array}{l}\text { Geometric } \\
\text { mean }\end{array}$} & \multicolumn{2}{|c|}{ Enrichment values } \\
\hline & Minimum & Maximum & & & & Plant/plant & Plant/soil \\
\hline As & 0.01 & 1.8 & 34 & 100 & 0.17 & 0.28 & 0.18 \\
\hline $\mathrm{Au}(\mathrm{ppb})$ & 0.10 & 26 & 34 & 100 & 2.5 & 1.00 & 100 \\
\hline $\mathrm{Ba}$ & 10 & 180 & 34 & 100 & 36 & 0.82 & 0.47 \\
\hline $\mathrm{Br}$ & 0.8 & 100 & 34 & 100 & 14 & 0.56 & - \\
\hline $\mathrm{Ca}(\%)$ & 0.36 & 4.50 & 34 & 100 & 1.46 & 0.82 & 6.7 \\
\hline $\mathrm{Ce}$ & 0.07 & 7.9 & 34 & 100 & 0.51 & 0.61 & 0.046 \\
\hline $\mathrm{Co}$ & 0.20 & 1.3 & 34 & 100 & 0.40 & 0.85 & 0.54 \\
\hline $\mathrm{Cr}$ & 0.10 & 13 & 34 & 100 & 0.51 & 0.36 & 0.26 \\
\hline $\mathrm{Cs}$ & $\mathrm{N}(0.01)^{\mathrm{a}}$ & 0.45 & 33 & 97 & 0.023 & 0.29 & 0.061 \\
\hline $\mathrm{Eu}$ & $\mathrm{N}(0.05)$ & 0.15 & 2 & 6 & - & - & - \\
\hline $\mathrm{Fe}(\%)$ & 0.005 & 0.27 & 34 & 100 & 0.029 & 0.69 & 0.083 \\
\hline Hf & 0.01 & 0.93 & 34 & 100 & 0.06 & 0.46 & 0.043 \\
\hline $\mathrm{Hg}$ & $\mathrm{N}(0.05)$ & 0.08 & 1 & 3 & - & - & - \\
\hline K (\%) & 0.98 & 7.50 & 34 & 100 & 2.79 & 1.0 & 12 \\
\hline $\mathrm{La}$ & 0.06 & 4.2 & 34 & 100 & 0.37 & 0.69 & 0.061 \\
\hline $\mathrm{Lu}$ & 0.001 & 0.043 & $26^{\mathrm{b}}$ & $100^{\mathrm{b}}$ & 0.005 & 0.71 & 0.078 \\
\hline Mo & 0.03 & 4.2 & 34 & 100 & 0.49 & 0.61 & 0.79 \\
\hline $\mathrm{Na}(\%)$ & 0.007 & 0.27 & 34 & 100 & 0.036 & 0.72 & 0.17 \\
\hline $\mathrm{Nd}$ & $\mathrm{N}(0.30)^{\mathrm{a}}$ & 3.0 & 4 & 12 & - & - & - \\
\hline $\mathrm{Ni}$ & $\mathrm{N}(2.0)^{\mathrm{a}}$ & 5.0 & 1 & 3 & - & - & - \\
\hline $\mathrm{Rb}$ & 1.0 & 20 & $30^{\mathrm{b}}$ & $100^{\mathrm{b}}$ & 4.9 & 0.67 & 0.45 \\
\hline $\mathrm{Sb}$ & 0.003 & 1.4 & 34 & 100 & 0.03 & 0.60 & 0.17 \\
\hline $\mathrm{Sc}$ & 0.01 & 0.78 & 34 & 100 & 0.07 & 0.58 & 0.074 \\
\hline $\mathrm{Se}$ & $\mathrm{N}(0.10)^{\mathrm{a}}$ & 2.8 & 3 & 9 & - & - & - \\
\hline $\mathrm{Sm}$ & 0.01 & 0.49 & 34 & 100 & 0.04 & 0.67 & 0.045 \\
\hline $\mathrm{Sr}$ & 5 & 360 & 34 & 100 & 89 & 0.74 & 2.9 \\
\hline $\mathrm{Ta}$ & $\mathrm{N}(0.05)$ & 0.16 & 3 & 9 & - & - & - \\
\hline $\mathrm{Th}$ & $\mathrm{N}(0.03)^{\mathrm{a}}$ & 1.8 & 33 & 97 & 0.07 & 0.41 & 0.030 \\
\hline $\mathrm{U}$ & $\mathrm{N}(0.003)^{\mathrm{a}}$ & 0.30 & 31 & 91 & 0.009 & 0.30 & 0.012 \\
\hline $\mathrm{W}$ & $\mathrm{N}(0.01)^{\mathrm{a}}$ & 1.3 & 30 & 88 & 0.04 & 0.18 & - \\
\hline $\mathrm{Yb}$ & 0.001 & 0.27 & 34 & 100 & 0.015 & 0.38 & 0.063 \\
\hline $\mathrm{Zn}$ & 6.0 & 69 & 34 & 100 & 13 & 0.87 & 1.6 \\
\hline
\end{tabular}

Concentrations are in dry weight and are in parts per million (ppm), unless "(\%)" or "ppb" (parts per billion) shown after element symbol. $\mathrm{N}=$ not detected at the lower limit of determination shown in parentheses. Mean values based on unqualified analyses only. "_," indicates no meaningful value. Bolded maximum concentrations indicate those elements with highest ratio of maximum concentration to geometric mean value.

${ }^{a}$ Element has more than one lower limit of determination. Lowest value shown.

${ }^{\mathrm{b}}$ Element not determined for all samples. Percent based on actual number of samples analysed.

that samples of soils collected in the Northern Section are generally highly enriched $(1.6 \times-7.8 \times)$ in at least six elements (As, $\mathrm{Cr}, \mathrm{Li}, \mathrm{Ni}, \mathrm{Sb}$, and possibly $\mathrm{Au}$ ). High concentration levels for $\mathrm{As}, \mathrm{Au}$, and $\mathrm{Sb}$ were also found in mineralized samples from old mine dumps and tailings piles (Chaffee, M.A., 2006, unpub. data) and are related to local mineral deposits or the processing of their ores. Those for $\mathrm{Cr}, \mathrm{Li}$, and $\mathrm{Ni}$ are deemed to be a result of natural lithologic differences between this area and others included in this study. 
Plants: Sixteen species (Achy, Acsp, Amte, Asac, Asla, Cabo, Chbr, Chwm, Erci, Lohu, Loto, Luod, Mibi, Opba, Scsp, Spam; Appendix 1) were collected here. As compared to geometric mean values for elements in non-ashed plants collected for the entire region (Table 3), mean values for the Northern Section plants (Table 8) as a whole contain relatively high enrichment values $(1.9 \times$ to $2.8 \times)$ for three elements (As, Sb, W) (Plant/ plant column, Table 8), all of which are found in the mineral deposits of the Rand and(or) Atolia mining districts. A comparison of geometric mean values for dry weight data for the Northern Section plants (Table 8) (multiplied by a factor of 10) with those of soils from this study area (Table 7) suggests that, for elements common to both data sets, plant material is strongly enriched $(1.9 \times-80 \times)$ in seven elements $(\mathrm{Ca}, \mathrm{Cd}, \mathrm{K}, \mathrm{Mo}, \mathrm{Sr}, \mathrm{Zn}$, possibly $\mathrm{Au}$ ) (Plant/soil column, Table 8). Concentrations of most other elements are significantly lower in plants as compared to soils.

\subsubsection{Goldstone Study Area}

Soils: Geometric mean values for elements analysed in soil samples collected in the Goldstone area (Table 9) were compared to those in the regional data set for soils (Table 2). For elements determined in both data sets, these comparisons suggest that samples of soil collected locally are slightly enriched $(1.2 \times-1.6 \times)$ (Table 9) in $\mathrm{Be}, \mathrm{Ca}$, $\mathrm{Cu}, \mathrm{Sc}, \mathrm{Sr}, \mathrm{V}$, and possibly $\mathrm{Rb}$ and $\mathrm{Ta}$, the latter two of which have very small numbers of unqualified analyses. High concentration levels of these elements are natural and a result of lithologic differences between this area and others included in this study.

Plants: Sixteen species (Achy, Asla, Assp, Brsp, Cabo, Cacl, Chcm, Erci, Luod, Magl, Mibi, Opba, Plov, Scsp, Spam, Stex; Appendix 1) were collected here. As compared to the chemistry (dry weight) of plants collected for the entire region (Table 3), geometric mean values for the Goldstone plants as a whole (Table 10) are slightly more enriched $(1.3 \times-2.0 \times)$ in nine elements $(\mathrm{Ca}, \mathrm{Ce}, \mathrm{Cs}, \mathrm{Mo}, \mathrm{Na}, \mathrm{Rb}, \mathrm{Sr}, \mathrm{U}$, and W) (Plant/plant column, Table 10). A comparison of geometric mean values for dry weight data for Goldstone plants (Table 10) (multiplied by 10) with those of soils from this study area (Table 9) suggests that, for elements determined in both media, plant material is relatively enriched $(2.1 \times-65 \times)$ in seven elements $(\mathrm{Ca}, \mathrm{Cd}, \mathrm{K}, \mathrm{Mo}, \mathrm{Sr}, \mathrm{Zn}$, and possibly $\mathrm{Au}$; Plant/ soil column, Table 10). Concentrations of other elements are significantly lower in plants than in local soils.

\subsubsection{Goffs Study Area}

Soils: Geometric mean values for elements analysed in samples collected at Goffs were compared to those in the regional data set (Tables 2 and 11). For elements determined in both data sets, these comparisons suggest that samples of soil collected locally are slightly enriched $(1.3 \times-1.9 \times)$ (Table 11) in nine elements $(\mathrm{Ce}, \mathrm{La}, \mathrm{Nb}, \mathrm{Nd}, \mathrm{P}, \mathrm{Th}, \mathrm{Ti}, \mathrm{Y}, \mathrm{Yb})$. These slight overall enrichments can be ascribed entirely to lithologic differences between this study area and the region as a whole.

Plants: Five species (Chem, Dita, Opba, Plri, Scsp; Appendix 1) were analysed. Many samples were analysed both as dry, non-ashed material and as ash. A comparison of the geometric mean values for non-ashed samples from Goffs (Table 12) with those of the region as a whole (Table 3) shows that plants from the Goffs area are depleted in all elements relative to non-ashed plants collected for the entire region (Plant/plant column, Table 12). Because analyses for ashed plant material were only determined for samples 
Table 7

Summary statistics for 51 soil samples, Western Mojave Study Area, Northern Section, southeastern California, USA

\begin{tabular}{|c|c|c|c|c|c|c|}
\hline \multirow[t]{2}{*}{ Element } & \multicolumn{2}{|c|}{ Concentration range } & \multirow{2}{*}{$\begin{array}{l}\text { Number } \\
\text { unqualified }\end{array}$} & \multirow{2}{*}{$\begin{array}{l}\text { Percent } \\
\text { unqualified }\end{array}$} & \multirow{2}{*}{$\begin{array}{l}\text { Geometric } \\
\text { mean }\end{array}$} & \multirow{2}{*}{$\begin{array}{l}\text { Enrichment } \\
\text { value }\end{array}$} \\
\hline & Minimum & Maximum & & & & \\
\hline $\mathrm{Al}(\%)$ & 4.39 & 9.45 & 51 & 100 & 7.07 & 0.95 \\
\hline As & 7.0 & 510 & 51 & 100 & 45 & 6.0 \\
\hline $\mathrm{Au}(\mathrm{ppb})$ & $\mathrm{N}(0.10)^{\mathrm{a}}$ & 680 & 29 & 57 & 5.3 & 7.8 \\
\hline $\mathrm{Ba}$ & 650 & 1100 & 51 & 100 & 790 & 1.1 \\
\hline $\mathrm{Be}$ & 1.0 & 3.0 & $24^{\mathrm{b}}$ & $100^{\mathrm{b}}$ & 2.4 & 1.1 \\
\hline $\mathrm{Ca}(\%)$ & 1.37 & 7.13 & 51 & 100 & 2.20 & 0.83 \\
\hline $\mathrm{Cd}$ & $\mathrm{N}(0.05)$ & 0.29 & $23^{\mathrm{b}}$ & $98^{\mathrm{b}}$ & 0.15 & 1.0 \\
\hline $\mathrm{Ce}$ & 44 & 120 & 51 & 100 & 74 & 0.74 \\
\hline $\mathrm{Co}$ & 6 & 22 & 51 & 100 & 13 & 1.3 \\
\hline $\mathrm{Cr}$ & 37 & 170 & 51 & 100 & 66 & 1.9 \\
\hline Cs & 1.0 & 8.0 & $27^{\mathrm{b}}$ & $100^{\mathrm{b}}$ & 4.4 & 1.1 \\
\hline $\mathrm{Cu}$ & 16 & 44 & $24^{\mathrm{b}}$ & $100^{\mathrm{b}}$ & 27 & 1.4 \\
\hline $\mathrm{Eu}$ & $\mathrm{N}(1.1)^{\mathrm{a}}$ & 2.0 & 28 & 55 & 1.4 & 0.47 \\
\hline $\mathrm{Fe}(\%)$ & 2.34 & 5.95 & 51 & 100 & 3.81 & 1.0 \\
\hline $\mathrm{Ga}$ & 7 & 40 & $24^{\mathrm{b}}$ & $100^{\mathrm{b}}$ & 24 & 1.3 \\
\hline Hf & 8 & 16 & $27^{\mathrm{b}}$ & $100^{\mathrm{b}}$ & 11 & 1.0 \\
\hline $\mathrm{Hg}$ & 0.02 & 0.25 & $50^{\mathrm{b}}$ & $100^{\mathrm{b}}$ & 0.040 & 1.0 \\
\hline K (\%) & 1.85 & 3.14 & 51 & 100 & 2.20 & 1.0 \\
\hline $\mathrm{La}$ & 32 & 58 & 51 & 100 & 39 & 0.74 \\
\hline $\mathrm{Li}$ & 27 & 65 & $24^{\mathrm{b}}$ & $100^{\mathrm{b}}$ & 45 & 1.6 \\
\hline $\mathrm{Lu}$ & 0.31 & 0.63 & $27^{\mathrm{b}}$ & $100^{\mathrm{b}}$ & 0.41 & 0.89 \\
\hline $\mathrm{Mg}(\%)$ & 0.51 & 2.31 & 51 & 100 & 1.20 & 1.1 \\
\hline $\mathrm{Mn}$ & 470 & 900 & 51 & 100 & 680 & 1.0 \\
\hline Mo & $\mathrm{N}(1.0)^{\mathrm{a}}$ & 6.0 & 33 & 65 & 3.4 & 1.0 \\
\hline $\mathrm{Na}(\%)$ & 0.98 & 2.31 & 51 & 100 & 1.66 & 0.87 \\
\hline $\mathrm{Nb}$ & 6 & 33 & $24^{\mathrm{b}}$ & $100^{\mathrm{b}}$ & 19 & 0.73 \\
\hline $\mathrm{Nd}$ & 19 & 50 & 51 & 100 & 29 & 0.64 \\
\hline $\mathrm{Ni}$ & 14 & 160 & $24^{\mathrm{b}}$ & $100^{\mathrm{b}}$ & 43 & 2.2 \\
\hline $\mathrm{P}(\%)$ & 0.045 & 0.17 & 51 & 100 & 0.070 & 0.78 \\
\hline $\mathrm{Pb}$ & $\mathrm{N}(4.0)$ & 20 & $12^{\mathrm{b}}$ & $50^{\mathrm{b}}$ & 9.2 & 0.54 \\
\hline $\mathrm{Rb}$ & 50 & 140 & $27^{\mathrm{b}}$ & $100^{\mathrm{b}}$ & 86 & 0.97 \\
\hline $\mathrm{Sb}$ & $\mathrm{N}(1.0)$ & 43 & 48 & 94 & 5.0 & 1.7 \\
\hline $\mathrm{Sc}$ & 7.7 & 20 & 51 & 100 & 12 & 1.0 \\
\hline $\mathrm{Sm}$ & 4.8 & 7.9 & $27^{\mathrm{b}}$ & $100^{\mathrm{b}}$ & 6.0 & 0.90 \\
\hline $\mathrm{Sr}$ & 200 & 410 & $24^{\mathrm{b}}$ & $100^{\mathrm{b}}$ & 260 & 0.76 \\
\hline $\mathrm{Ta}$ & $\mathrm{N}(0.5)$ & 2.5 & $15^{\mathrm{b}}$ & $56^{\mathrm{b}}$ & 1.1 & 0.79 \\
\hline $\mathrm{Tb}$ & $\mathrm{N}(0.1)$ & 0.3 & $9^{\mathrm{b}}$ & $33^{\mathrm{b}}$ & - & - \\
\hline Th & $\mathrm{N}(6.0)$ & 40 & 50 & 98 & 13 & 0.76 \\
\hline $\mathrm{Ti}(\%)$ & 0.34 & 0.81 & 51 & 100 & 0.52 & 0.95 \\
\hline $\mathrm{U}$ & 2.7 & 9.3 & $27^{\mathrm{b}}$ & $100^{\mathrm{b}}$ & 4.0 & 0.95 \\
\hline V & 54 & 170 & 51 & 100 & 97 & 1.0 \\
\hline W & $\mathrm{N}(1.0)$ & 160 & $20^{\mathrm{b}}$ & $74^{\mathrm{b}}$ & 7.5 & 1.0 \\
\hline $\mathrm{Y}$ & 16 & 28 & $24^{\mathrm{b}}$ & $100^{\mathrm{b}}$ & 20 & 0.71 \\
\hline $\mathrm{Yb}$ & 2.0 & 4.2 & 51 & 100 & 2.7 & 0.93 \\
\hline $\mathrm{Zn}$ & 51 & 160 & 51 & 100 & 86 & 1.1 \\
\hline
\end{tabular}

Concentrations are in parts per million (ppm), unless "(\%)" or "ppb" (parts per billion) shown after element symbol. $\mathrm{N}=$ not detected at the lower limit of determination shown in parentheses. Mean values based on unqualified analyses only. "_," indicates no meaningful value. Bolded maximum concentrations indicate those elements with highest ratio of maximum concentration to geometric mean value.

${ }^{\mathrm{a}}$ Element has more than one lower limit of determination. Lowest value shown.

${ }^{\mathrm{b}}$ Element not determined for all samples. Percent based on actual number of samples analysed. 
Table 8

Summary statistics for 107 non-ashed plant samples, Western Mojave Study Area, Northern Section, southeastern California, USA

\begin{tabular}{|c|c|c|c|c|c|c|c|}
\hline \multirow[t]{2}{*}{ Element } & \multicolumn{2}{|c|}{ Concentration range } & \multirow{2}{*}{$\begin{array}{l}\text { Number } \\
\text { unqualified }\end{array}$} & \multirow{2}{*}{$\begin{array}{l}\text { Percent } \\
\text { unqualified }\end{array}$} & \multirow{2}{*}{$\begin{array}{l}\text { Geometric } \\
\text { mean }\end{array}$} & \multicolumn{2}{|c|}{ Enrichment values } \\
\hline & Minimum & Maximum & & & & Plant/plant & Plant/soil \\
\hline As & $\mathrm{N}(0.05)^{\mathrm{a}}$ & 21 & 105 & 98 & 1.7 & 2.8 & 0.38 \\
\hline $\mathrm{Au}(\mathrm{ppb})$ & $\mathrm{N}(0.10)^{\mathrm{a}}$ & 140 & 88 & 82 & 2.4 & 0.96 & 4.5 \\
\hline $\mathrm{Ba}$ & 7.0 & 170 & 107 & 100 & 49 & 1.1 & 0.62 \\
\hline $\mathrm{Br}$ & 4.2 & 230 & 107 & 100 & 29 & 1.2 & - \\
\hline $\mathrm{Ca}(\%)$ & 0.36 & 5.20 & 107 & 100 & 2.02 & 1.1 & 9.2 \\
\hline $\mathrm{Cd}$ & $\mathrm{N}(0.30)$ & 5.2 & $76^{\mathrm{b}}$ & $97^{\mathrm{b}}$ & 1.2 & 1.2 & 80 \\
\hline $\mathrm{Ce}$ & 0.07 & 7.0 & $29^{\mathrm{b}}$ & $100^{\mathrm{b}}$ & 0.78 & 0.93 & 0.11 \\
\hline $\mathrm{Co}$ & 0.10 & 4.2 & 107 & 100 & 0.50 & 1.1 & 0.38 \\
\hline $\mathrm{Cr}$ & 0.10 & 12 & 107 & 100 & 2.0 & 1.4 & 0.30 \\
\hline Cs & $\mathrm{N}(0.01)^{\mathrm{a}}$ & 0.55 & 79 & 74 & 0.12 & 1.5 & 0.27 \\
\hline $\mathrm{Eu}$ & $\mathrm{N}(0.05)$ & 0.14 & 10 & 9 & - & - & - \\
\hline $\mathrm{Fe}(\%)$ & 0.015 & 0.37 & 107 & 100 & 0.052 & 1.2 & 0.14 \\
\hline Hf & $\mathrm{N}(0.01)^{\mathrm{a}}$ & 1.1 & 91 & 85 & 0.16 & 1.2 & 0.15 \\
\hline $\mathrm{Hg}$ & $\mathrm{N}(0.05)$ & 0.11 & 4 & 4 & - & - & - \\
\hline K (\%) & 0.81 & 6.50 & 107 & 100 & 2.99 & 1.1 & 14 \\
\hline $\mathrm{La}$ & 0.11 & 3.7 & 107 & 100 & 0.59 & 1.1 & 0.15 \\
\hline $\mathrm{Lu}$ & $\mathrm{N}(0.001)^{\mathrm{a}}$ & 0.046 & $88^{\mathrm{b}}$ & $85^{\mathrm{b}}$ & 0.008 & 1.1 & 0.20 \\
\hline Mo & $\mathrm{N}(0.05)^{\mathrm{a}}$ & 9.9 & 103 & 96 & 0.83 & 1.0 & 2.4 \\
\hline $\mathrm{Na}(\%)$ & 0.01 & 0.75 & 107 & 100 & 0.055 & 1.1 & 0.33 \\
\hline $\mathrm{Nd}$ & $\mathrm{N}(0.50)^{\mathrm{a}}$ & 3.3 & 27 & 25 & 1.1 & 1.1 & 0.38 \\
\hline $\mathrm{Ni}$ & $\mathrm{N}(2.0)^{\mathrm{a}}$ & 13 & 8 & 7 & - & - & - \\
\hline $\mathrm{Rb}$ & $\mathrm{N}(1.0)^{\mathrm{a}}$ & 65 & $104^{\mathrm{b}}$ & $98^{\mathrm{b}}$ & 8.7 & 1.2 & 1.0 \\
\hline $\mathrm{Sb}$ & $0.003^{\mathrm{a}}$ & 1.8 & 107 & 100 & 0.11 & 2.2 & 0.22 \\
\hline $\mathrm{Sc}$ & 0.03 & 0.88 & 107 & 100 & 0.15 & 1.3 & 0.13 \\
\hline $\mathrm{Se}$ & $\mathrm{N}(0.10)^{\mathrm{a}}$ & 1.5 & 19 & 18 & 0.46 & 1.1 & - \\
\hline $\mathrm{Sm}$ & $\mathrm{N}(0.01)$ & 0.47 & 105 & 98 & 0.070 & 1.2 & 0.12 \\
\hline $\mathrm{Sr}$ & 5 & 450 & 107 & 100 & 110 & 0.92 & 4.2 \\
\hline $\mathrm{Ta}$ & $\mathrm{N}(0.05)$ & 0.22 & 13 & 12 & - & - & - \\
\hline Th & $\mathrm{N}(0.03)^{\mathrm{a}}$ & 1.2 & 85 & 79 & 0.21 & 1.2 & 0.16 \\
\hline $\mathrm{U}$ & $\mathrm{N}(0.003)^{\mathrm{a}}$ & 0.24 & 47 & 44 & 0.040 & 1.3 & 0.10 \\
\hline $\mathrm{W}$ & $\mathrm{N}(0.01)^{\mathrm{a}}$ & 3.3 & 75 & 70 & 0.42 & 1.9 & 0.56 \\
\hline $\mathrm{Yb}$ & $\mathrm{N}(0.001)^{\mathrm{a}}$ & 0.31 & 92 & 86 & 0.048 & 1.2 & 0.18 \\
\hline $\mathrm{Zn}$ & 6.0 & 53 & 107 & 100 & 16 & 1.1 & 1.9 \\
\hline
\end{tabular}

Concentrations are in dry weight and are in parts per million (ppm), unless "(\%)" or "ppb" (parts per billion) shown after element symbol. $\mathrm{N}=$ not detected at the lower limit of determination shown in parentheses. Mean values based on unqualified analyses only. "_, indicates no meaningful value. Bolded maximum concentrations indicate those elements with highest ratio of maximum concentration to geometric mean value.

${ }^{a}$ Element has more than one lower limit of determination. Lowest value shown.

${ }^{\mathrm{b}}$ Element not determined for all samples. Percent based on actual number of samples analysed.

from the Goffs and Chemehuevi Valley study areas (Table 1), we were unable to compare these local data with any confidence to a regional data set.

A comparison of geometric mean values for dry weight analyses for Goffs non-ashed plants (Table 12) (multiplied by 10) with those of Goffs soils (Plant/soil column, Table 12) suggests that, for elements determined in both media, plant material is relatively enriched 
Table 9

Summary statistics for 48 soil samples, Goldstone Study Area, southeastern California, USA

\begin{tabular}{|c|c|c|c|c|c|c|}
\hline \multirow[t]{2}{*}{ Element } & \multicolumn{2}{|c|}{ Concentration range } & \multirow{2}{*}{$\begin{array}{l}\text { Number } \\
\text { unqualified }\end{array}$} & \multirow{2}{*}{$\begin{array}{l}\text { Percent } \\
\text { unqualified }\end{array}$} & \multirow{2}{*}{$\begin{array}{l}\text { Geometric } \\
\text { mean }\end{array}$} & \multirow{2}{*}{$\begin{array}{l}\text { Enrichment } \\
\text { value }\end{array}$} \\
\hline & Minimum & Maximum & & & & \\
\hline $\mathrm{Al}(\%)$ & 5.44 & 10.42 & 48 & 100 & 8.15 & 1.1 \\
\hline As & 2.0 & 72 & 48 & 100 & 6.6 & 0.88 \\
\hline $\mathrm{Au}(\mathrm{ppb})$ & $\mathrm{N}(0.10)^{\mathrm{a}}$ & 570 & 22 & 46 & 0.46 & 0.68 \\
\hline $\mathrm{Ba}$ & 480 & 900 & 48 & 100 & 720 & 0.97 \\
\hline $\mathrm{Be}$ & 2.0 & 3.0 & $39^{\mathrm{b}}$ & $100^{\mathrm{b}}$ & 2.5 & 1.2 \\
\hline $\mathrm{Ca}(\%)$ & 1.69 & 12.0 & 48 & 100 & 3.35 & 1.3 \\
\hline $\mathrm{Cd}$ & 0.06 & 0.55 & $39^{\mathrm{b}}$ & $100^{\mathrm{b}}$ & 0.16 & 1.1 \\
\hline $\mathrm{Ce}$ & 57 & 150 & 48 & 100 & 82 & 0.82 \\
\hline $\mathrm{Co}$ & 5 & 20 & 48 & 100 & 10 & 1.0 \\
\hline $\mathrm{Cr}$ & 9 & 110 & 48 & 100 & 33 & 0.94 \\
\hline $\mathrm{Cs}$ & 1.0 & 5.0 & $9^{\mathrm{b}}$ & $100^{\mathrm{b}}$ & 2.9 & 0.74 \\
\hline $\mathrm{Cu}$ & 13 & 61 & $39^{\mathrm{b}}$ & $100^{\mathrm{b}}$ & 24 & 1.3 \\
\hline $\mathrm{Eu}$ & $\mathrm{N}(2.0)$ & 3.0 & 10 & 21 & 1.6 & 0.53 \\
\hline $\mathrm{Fe}(\%)$ & 2.31 & 4.86 & 48 & 100 & 3.64 & 0.95 \\
\hline $\mathrm{Ga}$ & 11 & 36 & $39^{\mathrm{b}}$ & $100^{\mathrm{b}}$ & 20 & 1.1 \\
\hline $\mathrm{Hf}$ & 9.0 & 12 & $9^{b}$ & $100^{\mathrm{b}}$ & 8.8 & 0.80 \\
\hline $\mathrm{Hg}$ & 0.02 & 0.15 & 26 & 54 & 0.030 & 0.75 \\
\hline $\mathrm{K}(\%)$ & 1.65 & 2.34 & 48 & 100 & 2.03 & 0.92 \\
\hline $\mathrm{La}$ & 27 & 79 & 48 & 100 & 43 & 0.81 \\
\hline $\mathrm{Li}$ & 21 & 52 & $39^{\mathrm{b}}$ & $100^{\mathrm{b}}$ & 32 & 1.1 \\
\hline $\mathrm{Lu}$ & 0.31 & 0.57 & $9^{b}$ & $100^{\mathrm{b}}$ & 0.41 & 0.89 \\
\hline $\operatorname{Mg}(\%)$ & 0.82 & 1.78 & 48 & 100 & 1.20 & 1.1 \\
\hline $\mathrm{Mn}$ & 430 & 3400 & 48 & 100 & 700 & 1.0 \\
\hline Mo & $\mathrm{N}(1.0)^{\mathrm{a}}$ & 6.0 & 20 & 42 & 3.5 & 1.0 \\
\hline $\mathrm{Na}(\%)$ & 0.74 & 2.69 & 48 & 100 & 1.90 & 1.0 \\
\hline $\mathrm{Nb}$ & 13 & 190 & $39^{\mathrm{b}}$ & $100^{\mathrm{b}}$ & 28 & 1.1 \\
\hline $\mathrm{Nd}$ & 22 & 64 & 48 & 100 & 35 & 0.78 \\
\hline $\mathrm{Ni}$ & 11 & 46 & $39^{\mathrm{b}}$ & $100^{\mathrm{b}}$ & 22 & 1.1 \\
\hline $\mathrm{P}(\%)$ & 0.030 & 0.11 & 48 & 100 & 0.060 & 0.67 \\
\hline $\mathrm{Pb}$ & $\mathrm{N}(4.0)$ & 45 & $39^{\mathrm{b}}$ & $95^{\mathrm{b}}$ & 15 & 0.88 \\
\hline $\mathrm{Rb}$ & 29 & 140 & $9^{b}$ & $100^{\mathrm{b}}$ & 130 & 1.5 \\
\hline $\mathrm{Sb}$ & $\mathrm{N}(1.0)$ & 2.1 & 15 & 31 & 1.6 & 0.55 \\
\hline $\mathrm{Sc}$ & 7.0 & 18 & 48 & 100 & 14 & 1.2 \\
\hline $\mathrm{Sm}$ & 5.2 & 8.4 & $9^{b}$ & $100^{\mathrm{b}}$ & 7.7 & 1.1 \\
\hline $\mathrm{Sr}$ & 290 & 660 & $39^{\mathrm{b}}$ & $100^{\mathrm{b}}$ & 540 & 1.6 \\
\hline $\mathrm{Ta}$ & $\mathrm{N}(0.5)$ & 2.1 & $6^{\mathrm{b}}$ & $67^{\mathrm{b}}$ & 1.7 & 1.2 \\
\hline $\mathrm{Tb}$ & $\mathrm{N}(0.5)$ & 0.7 & $3^{\mathrm{b}}$ & $43^{\mathrm{b}}$ & - & - \\
\hline Th & $\mathrm{N}(6.0)$ & 40 & 47 & 98 & 18 & 1.1 \\
\hline $\mathrm{Ti}(\%)$ & 0.36 & 0.66 & 48 & 100 & 0.55 & 1.0 \\
\hline $\mathrm{U}$ & 2.3 & 4.2 & $9^{b}$ & $100^{\mathrm{b}}$ & 4.1 & 0.98 \\
\hline V & 57 & 140 & 48 & 100 & 120 & 1.3 \\
\hline W & $\mathrm{N}(1.0)$ & 9.0 & $2^{\mathrm{b}}$ & $22^{\mathrm{b}}$ & - & - \\
\hline $\mathrm{Y}$ & 13 & 75 & $39^{\mathrm{b}}$ & $100^{\mathrm{b}}$ & 28 & 1.0 \\
\hline $\mathrm{Yb}$ & 1.0 & 4.0 & 48 & 100 & 2.4 & 0.83 \\
\hline $\mathrm{Zn}$ & 48 & 110 & 48 & 100 & 75 & 0.96 \\
\hline
\end{tabular}

Concentrations are in parts per million (ppm), unless "(\%)" or "ppb" (parts per billion) shown after element symbol. $\mathrm{N}=$ not detected at the lower limit of determination shown in parentheses. Mean values based on unqualified analyses only. "- " indicates no meaningful value. Bolded maximum concentrations indicate those elements with highest ratio of maximum concentration to geometric mean value.

${ }^{a}$ Element has more than one lower limit of determination. Lowest value shown.

${ }^{b}$ Element not determined for all samples. Percent based on actual number of samples analysed. 
Table 10

Summary statistics for 109 non-ashed plant samples, Goldstone Study Area, southeastern California, USA

\begin{tabular}{|c|c|c|c|c|c|c|c|}
\hline \multirow[t]{2}{*}{ Element } & \multicolumn{2}{|c|}{ Concentration range } & \multirow{2}{*}{$\begin{array}{l}\text { Number } \\
\text { unqualified }\end{array}$} & \multirow{2}{*}{$\begin{array}{l}\text { Percent } \\
\text { unqualified }\end{array}$} & \multirow{2}{*}{$\begin{array}{l}\text { Geometric } \\
\text { mean }\end{array}$} & \multicolumn{2}{|c|}{ Enrichment values } \\
\hline & Minimum & Maximum & & & & Plant/plant & Plant/soil \\
\hline As & $\mathrm{N}(0.01)^{\mathrm{a}}$ & 5.6 & 104 & 95 & 0.71 & 1.2 & 1.1 \\
\hline $\mathrm{Au}(\mathrm{ppb})$ & $\mathrm{N}(0.10)^{\mathrm{a}}$ & 72 & 90 & 83 & 3.0 & 1.2 & 65 \\
\hline $\mathrm{Ba}$ & $\mathrm{N}(5.0)$ & 140 & 108 & 99 & 48 & 1.1 & 0.67 \\
\hline $\mathrm{Br}$ & 5.2 & 160 & 109 & 100 & 29 & 1.2 & - \\
\hline $\mathrm{Ca}(\%)$ & 0.41 & 8.60 & 109 & 100 & 2.29 & 1.3 & 6.8 \\
\hline $\mathrm{Cd}$ & $\mathrm{N}(0.30)$ & 2.9 & $85^{\mathrm{b}}$ & $100^{\mathrm{b}}$ & 0.99 & 1.0 & 62 \\
\hline $\mathrm{Ce}$ & 0.07 & 4.5 & $23^{\mathrm{b}}$ & $100^{\mathrm{b}}$ & 1.3 & 1.5 & 0.16 \\
\hline $\mathrm{Co}$ & 0.20 & 2.6 & 109 & 100 & 0.46 & 0.98 & 0.46 \\
\hline $\mathrm{Cr}$ & $\mathrm{N}(0.30)$ & 11 & 108 & 99 & 1.6 & 1.1 & 0.48 \\
\hline Cs & $\mathrm{N}(0.01)$ & 0.41 & 75 & 69 & 0.099 & 1.3 & 0.34 \\
\hline $\mathrm{Eu}$ & $\mathrm{N}(0.05)$ & 0.09 & 7 & 6 & - & - & - \\
\hline $\mathrm{Fe}(\%)$ & 0.014 & 0.28 & 109 & 100 & 0.047 & 1.1 & 0.13 \\
\hline Hf & $\mathrm{N}(0.01)^{\mathrm{a}}$ & 0.70 & 92 & 84 & 0.14 & 1.1 & 0.16 \\
\hline $\mathrm{Hg}$ & $\mathrm{N}(0.05)$ & 0.14 & 2 & 2 & - & - & - \\
\hline K (\%) & 1.50 & 7.90 & 109 & 100 & 3.18 & 1.2 & 16 \\
\hline $\mathrm{La}$ & 0.15 & 2.5 & 109 & 100 & 0.56 & 1.0 & 0.13 \\
\hline $\mathrm{Lu}$ & $\mathrm{N}(0.001)^{\mathrm{a}}$ & 0.029 & $94^{\mathrm{b}}$ & $86^{\mathrm{b}}$ & 0.0070 & 1.0 & 0.17 \\
\hline Mo & $\mathrm{N}(0.05)$ & 9.2 & 108 & 99 & 1.3 & 1.6 & 3.7 \\
\hline $\mathrm{Na}(\%)$ & 0.013 & 0.78 & 109 & 100 & 0.070 & 1.4 & 0.37 \\
\hline $\mathrm{Nd}$ & $\mathrm{N}(0.30)^{\mathrm{a}}$ & 1.7 & 40 & 37 & 0.91 & 0.91 & 0.26 \\
\hline $\mathrm{Ni}$ & $\mathrm{N}(2.0)$ & 8.0 & 7 & 6 & - & - & - \\
\hline $\mathrm{Rb}$ & $\mathrm{N}(1.0)$ & 78 & $107^{\mathrm{b}}$ & $99^{\mathrm{b}}$ & 9.2 & 1.3 & 0.71 \\
\hline $\mathrm{Sb}$ & $\mathrm{N}(0.005)^{\mathrm{a}}$ & 0.29 & 105 & 96 & 0.050 & 1.0 & 0.31 \\
\hline $\mathrm{Sc}$ & 0.03 & 0.82 & 109 & 100 & 0.13 & 1.1 & 0.093 \\
\hline $\mathrm{Se}$ & $\mathrm{N}(0.10)^{\mathrm{a}}$ & 0.90 & 24 & 22 & 0.40 & 0.95 & - \\
\hline $\mathrm{Sm}$ & 0.02 & 0.32 & 109 & 100 & 0.070 & 1.2 & 0.090 \\
\hline $\mathrm{Sr}$ & 20 & 470 & 109 & 100 & 150 & 1.3 & 2.8 \\
\hline $\mathrm{Ta}$ & $\mathrm{N}(0.05)$ & 0.08 & 6 & 6 & - & - & - \\
\hline $\mathrm{Th}$ & $\mathrm{N}(0.03)^{\mathrm{a}}$ & 0.8 & 76 & 70 & 0.19 & 1.1 & 0.11 \\
\hline $\mathrm{U}$ & $\mathrm{N}(0.003)^{\mathrm{a}}$ & 0.16 & 33 & 30 & 0.050 & 1.7 & 0.12 \\
\hline W & $\mathrm{N}(0.01)^{\mathrm{a}}$ & 3.7 & 62 & 57 & 0.44 & 2.0 & - \\
\hline $\mathrm{Yb}$ & $\mathrm{N}(0.001)$ & 0.20 & 93 & 85 & 0.049 & 1.2 & 0.20 \\
\hline $\mathrm{Zn}$ & 5.0 & 52 & 109 & 100 & 16 & 1.1 & 2.1 \\
\hline
\end{tabular}

Concentrations are in dry weight and are in parts per million (ppm), unless "(\%)" or "ppb" (parts per billion) shown after element symbol. $\mathrm{N}=$ not detected at the lower limit of determination shown in parentheses. Mean values based on unqualified analyses only. "_," indicates no meaningful value. Bolded maximum concentrations indicate those elements with highest ratio of maximum concentration to geometric mean value.

${ }^{a}$ Element has more than one lower limit of determination. Lowest value shown.

${ }^{\mathrm{b}}$ Element not determined for all samples. Percent based on actual number of samples analysed.

$(1.3 \times-41 \times)$ in five elements $(\mathrm{Ca}, \mathrm{Cd}, \mathrm{K}, \mathrm{Sr}, \mathrm{Zn})$. A similar comparison of geometric mean values for ashed data for Goffs plants (Table 13) with those of soils from this study area (Table 11) suggests that, for elements determined in both media, plant ash is relatively enriched $(1.3 \times-14 \times)$ in eight elements $(\mathrm{Ca}, \mathrm{Cd}, \mathrm{Cu}, \mathrm{Mg}, \mathrm{Mn}, \mathrm{Mo}, \mathrm{Sr}, \mathrm{Zn})$ (Table 13). Mean concentrations of most other elements are significantly lower in plants than in local soils. 
Table 11

Summary statistics for 50 soil samples, Goffs Study Area, southeastern California, USA

\begin{tabular}{|c|c|c|c|c|c|c|}
\hline \multirow[t]{2}{*}{ Element } & \multicolumn{2}{|c|}{ Concentration range } & \multirow{2}{*}{$\begin{array}{l}\text { Number } \\
\text { unqualified }\end{array}$} & \multirow{2}{*}{$\begin{array}{l}\text { Percent } \\
\text { unqualified }\end{array}$} & \multirow{2}{*}{$\begin{array}{l}\text { Geometric } \\
\text { mean }\end{array}$} & \multirow{2}{*}{$\begin{array}{l}\text { Enrichment } \\
\text { value }\end{array}$} \\
\hline & Minimum & Maximum & & & & \\
\hline $\mathrm{Al}(\%)$ & 7.14 & 7.87 & 50 & 100 & 7.47 & 1.0 \\
\hline As & 2.0 & 7.0 & 50 & 100 & 3.4 & 0.45 \\
\hline $\mathrm{Au}(\mathrm{ppb})$ & $\mathrm{N}(0.10)$ & 0.20 & 4 & 8 & - & - \\
\hline $\mathrm{Ba}$ & 640 & 820 & 50 & 100 & 730 & 0.99 \\
\hline $\mathrm{Be}$ & 2.0 & 2.0 & 50 & 100 & 2.0 & 0.95 \\
\hline $\mathrm{Ca}(\%)$ & 1.96 & 3.29 & 50 & 100 & 2.42 & 0.91 \\
\hline $\mathrm{Cd}$ & 0.07 & 0.22 & 50 & 100 & 0.14 & 0.93 \\
\hline $\mathrm{Ce}$ & 110 & 200 & 50 & 100 & 150 & 1.5 \\
\hline $\mathrm{Co}$ & 8 & 12 & 50 & 100 & 10 & 1.0 \\
\hline $\mathrm{Cr}$ & 18 & 38 & 50 & 100 & 26 & 0.74 \\
\hline $\mathrm{Cu}$ & 10 & 29 & 50 & 100 & 18 & 0.95 \\
\hline $\mathrm{Eu}$ & 2.0 & 5.0 & 50 & 100 & 3.4 & 1.1 \\
\hline $\mathrm{Fe}(\%)$ & 3.22 & 5.56 & 50 & 100 & 4.68 & 1.2 \\
\hline $\mathrm{Ga}$ & 11 & 26 & 50 & 100 & 19 & 1.0 \\
\hline K (\%) & 2.22 & 2.77 & 50 & 100 & 2.38 & 1.1 \\
\hline $\mathrm{La}$ & 51 & 96 & 50 & 100 & 72 & 1.4 \\
\hline $\mathrm{Li}$ & 17 & 32 & 50 & 100 & 23 & 0.79 \\
\hline $\operatorname{Mg}(\%)$ & 0.78 & 1.23 & 50 & 100 & 1.02 & 0.93 \\
\hline $\mathrm{Mn}$ & 560 & 930 & 50 & 100 & 770 & 1.1 \\
\hline Mo & 2.0 & 4.0 & 50 & 100 & 2.9 & 0.85 \\
\hline $\mathrm{Na}(\%)$ & 1.75 & 2.46 & 50 & 100 & 2.09 & 1.1 \\
\hline $\mathrm{Nb}$ & 21 & 48 & 50 & 100 & 36 & 1.4 \\
\hline $\mathrm{Nd}$ & 50 & 99 & 50 & 100 & 77 & 1.7 \\
\hline $\mathrm{Ni}$ & 12 & 20 & 50 & 100 & 16 & 0.80 \\
\hline $\mathrm{P}(\%)$ & 0.080 & 0.245 & 50 & 100 & 0.171 & 1.9 \\
\hline $\mathrm{Pb}$ & 11 & 23 & 50 & 100 & 17 & 1.0 \\
\hline $\mathrm{Sb}$ & $\mathrm{N}(1.0)$ & 2.0 & 1 & 2 & - & - \\
\hline $\mathrm{Sc}$ & 10 & 16 & 50 & 100 & 14 & 1.2 \\
\hline $\mathrm{Sr}$ & 310 & 380 & 50 & 100 & 340 & 1.0 \\
\hline $\mathrm{Th}$ & 14 & 44 & 50 & 100 & 22 & 1.3 \\
\hline Ti (\%) & 0.44 & 1.0 & 50 & 100 & 0.76 & 1.4 \\
\hline $\mathrm{V}$ & 72 & 140 & 50 & 100 & 100 & 1.1 \\
\hline $\mathrm{Y}$ & 25 & 54 & 50 & 100 & 42 & 1.5 \\
\hline $\mathrm{Yb}$ & 3.0 & 5.0 & 50 & 100 & 3.8 & 1.3 \\
\hline $\mathrm{Zn}$ & 49 & 95 & 50 & 100 & 77 & 0.99 \\
\hline
\end{tabular}

Concentrations are in parts per million (ppm), unless “(\%)" or "ppb" (parts per billion) shown after element symbol. $\mathrm{N}=$ not detected at the lower limit of determination shown in parentheses. Mean values based on unqualified analyses only. "_, indicates no meaningful value. Bolded maximum concentration indicates the only element with a high ratio of maximum concentration to geometric mean value.

\subsubsection{Chemehuevi Valley Study Area}

Soils and stream sediments: Soil samples were collected mostly along traverses near US Highway 95. In contrast, sediments were collected over a wider area to provide additional information on the chemistry of the area. Mean values for elements analysed in soil samples collected here were compared to those in the regional data set for soils (Tables 2 and 14). For elements determined in both data sets, these comparisons indicate that samples of soils collected in the Chemehuevi Valley are slightly enriched $(1.2 \times-1.3 \times)$ 
Table 12

Summary statistics for 35 non-ashed plant samples, Goffs Study Area, southeastern California, USA

\begin{tabular}{|c|c|c|c|c|c|c|c|}
\hline \multirow[t]{2}{*}{ Element } & \multicolumn{2}{|c|}{ Concentration range } & \multirow{2}{*}{$\begin{array}{l}\text { Number } \\
\text { unqualified }\end{array}$} & \multirow{2}{*}{$\begin{array}{l}\text { Percent } \\
\text { unqualified }\end{array}$} & \multirow{2}{*}{$\begin{array}{l}\text { Geometric } \\
\text { mean }\end{array}$} & \multicolumn{2}{|c|}{ Enrichment values } \\
\hline & Minimum & Maximum & & & & Plant/plant & Plant/soil \\
\hline As & $\mathrm{N}(0.01)^{\mathrm{a}}$ & 0.30 & 31 & 89 & 0.090 & 0.15 & 0.26 \\
\hline $\mathrm{Au}(\mathrm{ppb})$ & $\mathrm{N}(0.10)$ & 13 & 27 & 77 & 0.92 & 0.37 & - \\
\hline $\mathrm{Ba}$ & $\mathrm{N}(5.0)$ & 77 & 31 & 89 & 24 & 0.55 & 0.33 \\
\hline $\mathrm{Br}$ & 11 & 58 & 35 & 100 & 24 & 0.96 & - \\
\hline $\mathrm{Ca}(\%)$ & 0.31 & 2.75 & 35 & 100 & 0.89 & 0.50 & 3.7 \\
\hline $\mathrm{Cd}$ & $\mathrm{N}(0.10)$ & 2.2 & 34 & 97 & 0.57 & 0.59 & 41 \\
\hline $\mathrm{Co}$ & 0.20 & 1.0 & 35 & 100 & 0.46 & 0.98 & 0.46 \\
\hline $\mathrm{Cr}$ & 0.30 & 5.4 & 35 & 100 & 1.2 & 0.86 & 0.46 \\
\hline Cs & $\mathrm{N}(0.05)$ & 0.18 & 6 & 17 & 0.072 & 0.91 & - \\
\hline $\mathrm{Fe}(\%)$ & 0.008 & 0.06 & 35 & 100 & 0.020 & 0.48 & 0.043 \\
\hline $\mathrm{Hf}$ & $\mathrm{N}(0.05)$ & 0.26 & 25 & 71 & 0.11 & 0.85 & - \\
\hline K (\%) & 0.34 & 3.06 & 35 & 100 & 1.40 & 0.53 & 5.9 \\
\hline $\mathrm{La}$ & 0.09 & 1.8 & 35 & 100 & 0.42 & 0.78 & 0.058 \\
\hline $\mathrm{Lu}$ & $\mathrm{N}(0.001)$ & 0.013 & 27 & 77 & 0.0050 & 0.71 & - \\
\hline Mo & $\mathrm{N}(0.05)$ & 16 & 28 & 80 & 0.23 & 0.29 & 0.79 \\
\hline $\mathrm{Na}(\%)$ & 0.0082 & 0.067 & 35 & 100 & 0.019 & 0.38 & 0.091 \\
\hline $\mathrm{Rb}$ & $\mathrm{N}(1.0)$ & 7.0 & 31 & 89 & 2.9 & 0.40 & - \\
\hline $\mathrm{Sb}$ & $\mathrm{N}(0.005)$ & 0.047 & 28 & 80 & 0.014 & 0.28 & - \\
\hline $\mathrm{Sc}$ & 0.01 & 0.18 & 35 & 100 & 0.050 & 0.42 & 0.036 \\
\hline $\mathrm{Sm}$ & 0.01 & 0.16 & 35 & 100 & 0.040 & 0.67 & - \\
\hline $\mathrm{Sr}$ & $\mathrm{N}(10)$ & 260 & 28 & 80 & 63 & 0.53 & 1.9 \\
\hline $\mathrm{Ta}$ & $\mathrm{N}(0.05)$ & 0.05 & 1 & 3 & - & - & - \\
\hline $\mathrm{Th}$ & $\mathrm{N}(0.1)$ & 0.60 & 10 & 29 & 0.13 & 0.76 & 0.059 \\
\hline $\mathrm{U}$ & $\mathrm{N}(0.01)$ & 0.13 & 4 & 11 & - & - & - \\
\hline $\mathrm{Yb}$ & $\mathrm{N}(0.005)$ & 0.076 & 26 & 74 & 0.031 & 0.78 & 0.082 \\
\hline $\mathrm{Zn}$ & 3.0 & 27 & 35 & 100 & 9.7 & 0.65 & 1.3 \\
\hline
\end{tabular}

Concentrations are in dry weight and are in parts per million (ppm), unless "(\%)" or "ppb" (parts per billion) shown after element symbol. $\mathrm{N}=$ not detected at the lower limit of determination shown in parentheses. Mean values based on unqualified analyses only. "_, indicates no meaningful value. Bolded maximum concentrations indicate those elements with highest ratio of maximum concentration to geometric mean value.

${ }^{a}$ Element has more than one lower limit of determination. Lowest value shown.

only in $\mathrm{Ca}, \mathrm{Cd}, \mathrm{Cr}$, and $\mathrm{Ni}$ (Soil/soil column, Table 14). Enrichment of $\mathrm{Ca}$ is probably related to formation of calcrete (caliche) in the B soil horizon. The possible enrichments of the other three elements are not understood and may only represent local contamination or an analytical artifact, because none of the other elements commonly associated with $\mathrm{Cd}$ (such as $\mathrm{Pb}$ or $\mathrm{Zn}$ ) or with $\mathrm{Cr}$ or $\mathrm{Ni}$ (such as $\mathrm{Co}, \mathrm{Fe}, \mathrm{Mg}$, or $\mathrm{Mn}$ ) is enriched in these samples.

When geometric mean values of elements determined in both local soils (Table 14) and stream sediments (Table 15) were compared, sediments were found to be generally enriched $(1.2 \times-36 \times)$ in at least 18 elements (As, $\mathrm{Au}, \mathrm{Cd}, \mathrm{Co}, \mathrm{Cr}, \mathrm{Cu}, \mathrm{Fe}, \mathrm{La}, \mathrm{Mn}, \mathrm{Ni}$, $\mathrm{Pb}, \mathrm{Sc}, \mathrm{Th}, \mathrm{Ti}, \mathrm{V}, \mathrm{Y}, \mathrm{Yb}, \mathrm{Zn})($ Table 15$)$, whereas soils were enriched $(1.2 \times-2.1 \times)$ in $\mathrm{Al}$, $\mathrm{Eu}, \mathrm{K}, \mathrm{Mo}$, and P (Soil/sed column, Table 14).

Plants: Three species (Chsp, Disp, Plov; Appendix 1) were collected in the study area, and all samples were ashed prior to analysis. A comparison of geometric mean values in 
Table 13

Summary statistics for 43 ashed plant samples, Goffs Study Area, southeastern California, USA

\begin{tabular}{|c|c|c|c|c|c|c|}
\hline \multirow[t]{2}{*}{ Element } & \multicolumn{2}{|c|}{ Concentration range } & \multirow{2}{*}{$\begin{array}{l}\text { Number } \\
\text { unqualified }\end{array}$} & \multirow{2}{*}{$\begin{array}{l}\text { Percent } \\
\text { unqualified }\end{array}$} & \multirow{2}{*}{$\begin{array}{l}\text { Geometric } \\
\text { mean }\end{array}$} & \multirow{2}{*}{$\begin{array}{l}\text { Enrichment } \\
\text { value }\end{array}$} \\
\hline & Minimum & Maximum & & & & \\
\hline $\mathrm{Ag}$ & $\mathrm{N}(0.02)$ & 1.1 & 5 & 12 & - & - \\
\hline $\mathrm{Al}(\%)$ & 0.068 & 0.97 & 43 & 100 & 0.27 & 0.036 \\
\hline As & 0.5 & 6.3 & 43 & 100 & 2.2 & 0.65 \\
\hline B & 66 & 900 & 43 & 100 & 200 & - \\
\hline $\mathrm{Ba}$ & 130 & 1000 & 43 & 100 & 400 & 0.55 \\
\hline $\mathrm{Be}$ & 0.02 & 0.42 & 43 & 100 & 0.080 & 0.040 \\
\hline $\mathrm{Bi}$ & 0.01 & 0.19 & $2^{\mathrm{a}}$ & $100^{\mathrm{a}}$ & - & - \\
\hline $\mathrm{Br}$ & 29 & 300 & 43 & 100 & 86 & - \\
\hline $\mathrm{Ca}(\%)$ & 5.56 & 24 & 43 & 100 & 13 & 5.4 \\
\hline $\mathrm{Cd}$ & 0.29 & 3.4 & 43 & 100 & 1.1 & 7.9 \\
\hline $\mathrm{Ce}$ & 2.2 & 20 & 43 & 100 & 6.3 & 0.042 \\
\hline $\mathrm{Co}$ & 1.2 & 5.0 & 43 & 100 & 3.0 & 0.30 \\
\hline $\mathrm{Cr}$ & 1.8 & 29 & 43 & 100 & 9.3 & 0.36 \\
\hline $\mathrm{Cs}$ & 0.15 & 2.5 & 43 & 100 & 0.49 & - \\
\hline $\mathrm{Cu}$ & 22 & 1200 & 43 & 100 & 260 & 14 \\
\hline Dy & 0.094 & 0.88 & 43 & 100 & 0.30 & - \\
\hline $\mathrm{Er}$ & 0.048 & 0.47 & 43 & 100 & 0.17 & - \\
\hline $\mathrm{Eu}$ & 0.05 & 0.38 & 43 & 100 & 0.16 & 0.047 \\
\hline $\mathrm{Fe}(\%)$ & 0.16 & 1.7 & 43 & 100 & 0.73 & 0.16 \\
\hline $\mathrm{Ga}$ & 0.32 & 2.2 & 43 & 100 & 0.84 & 0.044 \\
\hline Gd & 0.16 & 2.0 & 43 & 100 & 0.60 & - \\
\hline $\mathrm{Ge}$ & 0.01 & 0.15 & 43 & 100 & 0.060 & - \\
\hline $\mathrm{Hf}$ & 0.01 & 0.06 & $39^{\mathrm{a}}$ & $100^{\mathrm{a}}$ & 0.020 & - \\
\hline Но & 0.016 & 0.47 & 43 & 100 & 0.060 & - \\
\hline I & $\mathrm{N}(0.02)$ & 1.2 & 43 & 95 & 0.15 & - \\
\hline In & 1.3 & 13 & 43 & 100 & 4.1 & - \\
\hline K (\%) & 9.48 & $>34$ & 4 & 9 & - & - \\
\hline $\mathrm{La}$ & 1.3 & 11 & 43 & 100 & 3.8 & 0.053 \\
\hline $\mathrm{Li}$ & 2.0 & 75 & 43 & 100 & 11 & 0.48 \\
\hline $\mathrm{Lu}$ & 0.005 & 0.05 & 43 & 100 & 0.020 & - \\
\hline $\operatorname{Mg}(\%)$ & 1.28 & 12 & 43 & 100 & 3.9 & 3.8 \\
\hline $\mathrm{Mn}$ & 750 & 3600 & 43 & 100 & 1600 & 2.1 \\
\hline Mo & 0.54 & 290 & 43 & 100 & 3.8 & 1.3 \\
\hline $\mathrm{Na}(\%)$ & $\mathrm{N}(0.01)$ & 0.60 & 41 & 95 & 0.10 & 0.048 \\
\hline $\mathrm{Nb}$ & 0.05 & 0.48 & 43 & 100 & 0.14 & 0.0039 \\
\hline $\mathrm{Nd}$ & 0.88 & 8.4 & 43 & 100 & 2.6 & 0.034 \\
\hline $\mathrm{Ni}$ & 3.8 & 24 & 43 & 100 & 12 & 0.75 \\
\hline $\mathrm{Pb}$ & 0.88 & 8.6 & 43 & 100 & 2.9 & 0.17 \\
\hline $\operatorname{Pr}$ & 0.26 & 2.3 & 43 & 100 & 0.73 & - \\
\hline $\mathrm{Rb}$ & 16 & 68 & 43 & 100 & 36 & - \\
\hline $\mathrm{Re}$ & 27 & 1900 & 43 & 100 & 190 & - \\
\hline $\mathrm{Sb}$ & 0.01 & 0.11 & $26^{\mathrm{a}}$ & $100^{\mathrm{a}}$ & 0.030 & - \\
\hline $\mathrm{Sc}$ & 0.40 & 2.4 & 43 & 100 & 1.0 & 0.071 \\
\hline $\mathrm{Se}$ & 0.50 & 3.1 & 43 & 100 & 1.4 & - \\
\hline $\mathrm{Si}$ & 270 & 3300 & 43 & 100 & 1200 & - \\
\hline $\mathrm{Sm}$ & 0.15 & 1.6 & 43 & 100 & 0.50 & - \\
\hline $\mathrm{Sn}$ & $\mathrm{N}(1.0)$ & 1.0 & 1 & 2 & - & - \\
\hline $\mathrm{Sr}$ & 560 & 3700 & 43 & 100 & 1600 & 4.7 \\
\hline $\mathrm{Ta}$ & 0.01 & 0.02 & $15^{\mathrm{a}}$ & $100^{\mathrm{a}}$ & 0.010 & - \\
\hline
\end{tabular}


Table 13 (continued)

\begin{tabular}{|c|c|c|c|c|c|c|}
\hline \multirow[t]{2}{*}{ Element } & \multicolumn{2}{|c|}{ Concentration range } & \multirow{2}{*}{$\begin{array}{l}\text { Number } \\
\text { unqualified }\end{array}$} & \multirow{2}{*}{$\begin{array}{l}\text { Percent } \\
\text { unqualified }\end{array}$} & \multirow{2}{*}{$\begin{array}{l}\text { Geometric } \\
\text { mean }\end{array}$} & \multirow{2}{*}{$\begin{array}{l}\text { Enrichment } \\
\text { value }\end{array}$} \\
\hline & Minimum & Maximum & & & & \\
\hline $\mathrm{Tb}$ & 0.02 & 0.19 & 43 & 100 & 0.060 & - \\
\hline $\mathrm{Te}$ & 0.01 & 0.16 & $42^{\mathrm{a}}$ & $100^{\mathrm{a}}$ & 0.050 & - \\
\hline $\mathrm{Th}$ & 0.12 & 15 & 43 & 100 & 0.69 & 0.031 \\
\hline $\mathrm{Ti}(\%)$ & 0.0078 & 0.056 & 43 & 100 & 0.024 & - \\
\hline $\mathrm{Tl}$ & 0.04 & 0.41 & 43 & 100 & 0.13 & - \\
\hline $\mathrm{Tm}$ & 0.005 & 0.06 & 43 & 100 & 0.020 & - \\
\hline $\mathrm{U}$ & 0.02 & 1.7 & 43 & 100 & 0.11 & - \\
\hline V & 0.8 & 10 & 43 & 100 & 3.1 & 0.074 \\
\hline W & $\mathrm{N}(0.10)$ & 0.90 & 24 & 56 & 0.33 & - \\
\hline $\mathrm{Y}$ & 0.54 & 5.3 & 43 & 100 & 1.9 & 0.045 \\
\hline $\mathrm{Yb}$ & 0.034 & 0.34 & 43 & 100 & 0.12 & 0.032 \\
\hline $\mathrm{Zn}$ & 35 & 490 & 43 & 100 & 130 & 1.7 \\
\hline $\mathrm{Zr}$ & 0.02 & 0.49 & $37^{\mathrm{a}}$ & $100^{\mathrm{a}}$ & 0.13 & - \\
\hline
\end{tabular}

Concentrations are in ashed weight and are in parts per million (ppm), unless "(\%)" shown after element symbol. $\mathrm{N}=$ not detected at the lower limit of determination shown in parentheses. Mean values based on unqualified values only. "_-" indicates no meaningful value. Bolded maximum concentrations indicate those elements with highest ratio of maximum concentration to geometric mean value.

${ }^{a}$ Element not determined for all samples. Percent based on actual number of samples analysed.

ashed plants with mean values for soils and sediments from this study area suggests that, for those elements present in all three data sets (Tables 14-16), Chemehuevi Valley area plants are relatively enriched $(1.2 \times-7.2 \times)$ in seven elements $(\mathrm{As}, \mathrm{Ba}, \mathrm{Cd}, \mathrm{Cu}, \mathrm{Mo}, \mathrm{Sr}$, and $\mathrm{Zn}$ ) relative to soil concentrations (Plant/soil column, Table 16) and in five elements $(1.5 \times-3.2 \times)(\mathrm{Ba}, \mathrm{Cd}, \mathrm{Cu}, \mathrm{Mo}$, and $\mathrm{Sr})$ relative to sediment values (Plant/sed column, Table 16). Concentrations of most other elements are much lower in plants as compared to soils and sediments. No analyses were determined for $\mathrm{Ca}$ or $\mathrm{K}$ in plant ash. These two elements would normally be expected to have much higher concentrations in plant ash than in their substrate soils.

\subsubsection{Chuckwalla Bench Study Area}

Soils and stream sediments: Both soil and stream-sediment samples were collected at scattered locations to characterize the chemistry of the area. Mean values for elements analysed in soil samples collected at Chuckwalla Bench (Table 17) were compared to those in the regional data set (Table 2). For elements determined in both data sets, these comparisons suggest that samples of soil collected in the Chuckwalla Bench area are slightly enriched $(1.2 \times-1.7 \times)$ in $\mathrm{Ca}, \mathrm{Ce}, \mathrm{Cr}, \mathrm{La}, \mathrm{Nb}, \mathrm{Th}$, and $\mathrm{Ti}$ (Soil/soil column, Table 17). This apparent enrichment in Ca suggests that calcrete (caliche) is more dominant in these soils as compared to those in the region as a whole. Relatively high enrichment values for $\mathrm{Ce}, \mathrm{Cr}, \mathrm{La}, \mathrm{Nb}, \mathrm{Th}$, and $\mathrm{Ti}$ may represent differences in rock chemistry between the two areas. However, because only five soil samples were analysed, these observations may not be meaningful.

A comparison of geometric mean values of the elements determined in both soils and sediments from the Chuckwalla Bench area shows that the soils are slightly enriched $(1.2 \times-1.4 \times)$ in $\mathrm{Ba}, \mathrm{Ca}, \mathrm{Ce}, \mathrm{Mg}, \mathrm{Ni}$, and $\mathrm{P}$ (Soil/sed column, Table 17). In contrast, the 
Table 14

Summary statistics for 41 soil samples, Chemehuevi Valley Study Area, southeastern California, USA

\begin{tabular}{|c|c|c|c|c|c|c|c|}
\hline \multirow[t]{2}{*}{ Element } & \multicolumn{2}{|c|}{ Concentration range } & \multirow{2}{*}{$\begin{array}{l}\text { Number } \\
\text { unqualified }\end{array}$} & \multirow{2}{*}{$\begin{array}{l}\text { Percent } \\
\text { unqualified }\end{array}$} & \multirow{2}{*}{$\begin{array}{l}\text { Geometric } \\
\text { mean }\end{array}$} & \multicolumn{2}{|c|}{ Enrichment values } \\
\hline & Minimum & Maximum & & & & Soil/soil & Soil/sed \\
\hline $\mathrm{Al}(\%)$ & 6.28 & 8.00 & 41 & 100 & 6.74 & 0.90 & 1.2 \\
\hline As & 2.0 & 11 & 41 & 100 & 2.7 & 0.36 & 0.67 \\
\hline $\mathrm{Au}(\mathrm{ppb})$ & $\mathrm{N}(0.10)^{\mathrm{a}}$ & 0.20 & 9 & 22 & 0.14 & 0.21 & 0.028 \\
\hline $\mathrm{Ba}$ & 660 & 940 & 41 & 100 & 750 & 1.0 & 1.1 \\
\hline $\mathrm{Be}$ & 1.0 & 3.0 & 41 & 100 & 1.8 & 0.86 & - \\
\hline $\mathrm{Ca}(\%)$ & 2.59 & 5.12 & 41 & 100 & 3.10 & 1.2 & 0.91 \\
\hline $\mathrm{Cd}$ & 0.13 & 0.29 & 41 & 100 & 0.18 & 1.2 & 0.24 \\
\hline $\mathrm{Ce}$ & 69 & 130 & 41 & 100 & 100 & 1.0 & 0.91 \\
\hline $\mathrm{Co}$ & 9 & 16 & 41 & 100 & 11 & 1.1 & 0.67 \\
\hline $\mathrm{Cr}$ & 24 & 110 & 41 & 100 & 45 & 1.3 & 0.37 \\
\hline $\mathrm{Cu}$ & 13 & 33 & 41 & 100 & 18 & 0.95 & 0.77 \\
\hline $\mathrm{Eu}$ & $\mathrm{N}(2.0)$ & 3.0 & 19 & 46 & 2.6 & 0.87 & 1.4 \\
\hline $\mathrm{Fe}(\%)$ & 2.49 & 4.83 & 41 & 100 & 3.49 & 0.91 & 0.48 \\
\hline $\mathrm{Ga}$ & 12 & 32 & 41 & 100 & 20 & 1.1 & - \\
\hline $\mathrm{Hg}$ & $\mathrm{N}(0.02)$ & 0.03 & $2^{\mathrm{b}}$ & $8^{\mathrm{b}}$ & - & - & - \\
\hline K (\%) & 1.86 & 2.55 & 41 & 100 & 2.13 & 0.97 & 1.2 \\
\hline $\mathrm{La}$ & 41 & 64 & 41 & 100 & 50 & 0.94 & 0.77 \\
\hline $\mathrm{Li}$ & 16 & 30 & 41 & 100 & 22 & 0.76 & - \\
\hline $\operatorname{Mg}(\%)$ & 1.04 & 1.57 & 41 & 100 & 1.21 & 1.1 & 0.91 \\
\hline $\mathrm{Mn}$ & 490 & 710 & 41 & 100 & 600 & 0.88 & 0.59 \\
\hline Mo & 2 & 7 & 41 & 100 & 3.2 & 0.94 & 1.5 \\
\hline $\mathrm{Na}(\%)$ & 1.49 & 2.08 & 41 & 100 & 1.81 & 0.95 & 1.0 \\
\hline $\mathrm{Nb}$ & 5 & 32 & 41 & 100 & 20 & 0.77 & - \\
\hline $\mathrm{Nd}$ & 29 & 65 & 41 & 100 & 44 & 0.98 & 1.1 \\
\hline $\mathrm{Ni}$ & 20 & 31 & 41 & 100 & 23 & 1.2 & 0.77 \\
\hline $\mathrm{P}(\%)$ & 0.055 & 0.11 & 41 & 100 & 0.090 & 1.0 & 2.1 \\
\hline $\mathrm{Pb}$ & 10 & 51 & 41 & 100 & 17 & 1.0 & 0.83 \\
\hline $\mathrm{Sc}$ & 9.0 & 15 & 41 & 100 & 12 & 1.0 & 0.77 \\
\hline $\mathrm{Sr}$ & 290 & 440 & 41 & 100 & 350 & 1.0 & 1.0 \\
\hline $\mathrm{Th}$ & 9 & 31 & 41 & 100 & 15 & 0.88 & 0.77 \\
\hline Ti (\%) & 0.40 & 0.70 & 41 & 100 & 0.54 & 0.98 & 0.63 \\
\hline $\mathrm{V}$ & 68 & 140 & 41 & 100 & 98 & 1.0 & 0.56 \\
\hline $\mathrm{Y}$ & 21 & 34 & 41 & 100 & 28 & 1.0 & 0.71 \\
\hline $\mathrm{Yb}$ & 2.0 & 4.0 & 41 & 100 & 3.1 & 1.1 & 0.59 \\
\hline $\mathrm{Zn}$ & 61 & 120 & 41 & 100 & 75 & 0.96 & 0.77 \\
\hline
\end{tabular}

Concentrations are in parts per million (ppm), unless “(\%)" or "ppb” (parts per billion) shown after element symbol. $\mathrm{N}=$ not detected at the lower limit of determination shown in parentheses. Mean values based on unqualified analyses only. "_-" indicates no meaningful value. Bolded maximum concentrations indicate those elements with highest ratio of maximum concentration to geometric mean value.

${ }^{a}$ Element has more than one lower limit of determination. Lowest value shown.

${ }^{\mathrm{b}}$ Element not determined for all samples. Percent based on actual number of samples analysed.

sediments are relatively enriched $(1.2 \times-45 \times)$ in $\mathrm{As}, \mathrm{Cu}, \mathrm{Fe}, \mathrm{La}, \mathrm{Mn}, \mathrm{Nd}, \mathrm{Pb}, \mathrm{Th}, \mathrm{Ti}, \mathrm{V}$, $\mathrm{Y}, \mathrm{Yb}, \mathrm{Zn}$, and probably Au (Table 18). The elements enriched in the sediments are mainly associated with magnetite and other heavy minerals that are often found concentrated in sediments. 
Table 15

Summary statistics for 22 stream-sediment samples, Chemehuevi Valley Study Area, southeastern California, USA

\begin{tabular}{|c|c|c|c|c|c|c|}
\hline \multirow[t]{2}{*}{ Element } & \multicolumn{2}{|c|}{ Concentration range } & \multirow{2}{*}{$\begin{array}{l}\text { Number } \\
\text { unqualified }\end{array}$} & \multirow{2}{*}{$\begin{array}{l}\text { Percent } \\
\text { unqualified }\end{array}$} & \multirow{2}{*}{$\begin{array}{l}\text { Geometric } \\
\text { mean }\end{array}$} & \multirow{2}{*}{$\begin{array}{l}\text { Enrichment } \\
\text { value }\end{array}$} \\
\hline & Minimum & Maximum & & & & \\
\hline $\mathrm{Al}(\%)$ & 3.90 & 6.89 & 22 & 100 & 5.73 & 0.85 \\
\hline As & 2.5 & 5.8 & 22 & 100 & 4.0 & 1.5 \\
\hline $\mathrm{Au}$ & $\mathrm{N}(2.0)$ & 11 & 6 & 27 & 5.1 & 36 \\
\hline $\mathrm{Ba}$ & 460 & 1100 & 22 & 100 & 680 & 0.91 \\
\hline $\mathrm{Be}$ & $\mathrm{N}(2.0)$ & 2.0 & 4 & 18 & - & - \\
\hline $\mathrm{Ca}(\%)$ & 2.67 & 7.48 & 22 & 100 & 3.29 & 1.1 \\
\hline $\mathrm{Cd}$ & $\mathrm{N}(0.5)$ & 1.10 & 6 & 27 & 0.73 & 4.1 \\
\hline $\mathrm{Ce}$ & 86 & 270 & 22 & 100 & 110 & 1.1 \\
\hline $\mathrm{Co}$ & 8 & 39 & 22 & 100 & 17 & 1.5 \\
\hline $\mathrm{Cr}$ & 56 & 340 & 22 & 100 & 120 & 2.7 \\
\hline Cs & $\mathrm{N}(1.0)$ & 3.0 & 12 & 55 & 2.0 & - \\
\hline $\mathrm{Cu}$ & 14 & 52 & 22 & 100 & 24 & 1.3 \\
\hline $\mathrm{Eu}$ & 1.5 & 2.9 & 22 & 100 & 1.8 & 0.69 \\
\hline $\mathrm{Fe}(\%)$ & 3.13 & 21.2 & 22 & 100 & 7.25 & 2.1 \\
\hline Hf & 16 & 52 & 22 & 100 & 25 & - \\
\hline K $(\%)$ & 0.99 & 2.16 & 22 & 100 & 1.77 & 0.83 \\
\hline $\mathrm{La}$ & 51 & 170 & 22 & 100 & 63 & 1.3 \\
\hline $\mathrm{Lu}$ & 0.55 & 1.36 & 22 & 100 & 0.81 & - \\
\hline $\operatorname{Mg}(\%)$ & 0.82 & 1.83 & 22 & 100 & 1.32 & 1.1 \\
\hline $\mathrm{Mn}$ & 550 & 2100 & 22 & 100 & 990 & 1.7 \\
\hline Mo & $\mathrm{N}(2.0)$ & 3.0 & 13 & 59 & 2.1 & 0.66 \\
\hline $\mathrm{Na}(\%)$ & 1.17 & 2.41 & 22 & 100 & 1.77 & 0.98 \\
\hline $\mathrm{Nd}$ & 31 & 89 & 22 & 100 & 42 & 0.95 \\
\hline $\mathrm{Ni}$ & 11 & 49 & 22 & 100 & 29 & 1.3 \\
\hline P (\%) & 0.007 & 0.082 & 22 & 100 & 0.042 & 0.47 \\
\hline $\mathrm{Pb}$ & 15 & 32 & 22 & 100 & 21 & 1.2 \\
\hline $\mathrm{Rb}$ & $\mathrm{N}(15)$ & 93 & 17 & 77 & 60 & - \\
\hline $\mathrm{Sb}$ & 0.60 & 0.90 & 22 & 100 & 0.73 & - \\
\hline $\mathrm{Sc}$ & 9.4 & 24 & 22 & 100 & 16 & 1.3 \\
\hline $\mathrm{Sm}$ & 6.7 & 16 & 22 & 100 & 8.9 & - \\
\hline $\mathrm{Sr}$ & 260 & 460 & 22 & 100 & 350 & 1.0 \\
\hline $\mathrm{Ta}$ & $\mathrm{N}(0.5)$ & 5.0 & 15 & 68 & 2.0 & - \\
\hline $\mathrm{Tb}$ & $\mathrm{N}(0.5)$ & 2.7 & 19 & 86 & 1.4 & - \\
\hline $\mathrm{Th}$ & 14 & 62 & 22 & 100 & 19 & 1.3 \\
\hline $\mathrm{Ti}(\%)$ & 0.31 & 2.08 & 22 & 100 & 0.84 & 1.6 \\
\hline $\mathrm{U}$ & $\mathrm{N}(0.5)$ & 11 & 21 & 95 & 3.6 & - \\
\hline V & 64 & 550 & 22 & 100 & 180 & 1.8 \\
\hline W & $\mathrm{N}(1.0)$ & 3.0 & 3 & 14 & - & - \\
\hline $\mathrm{Y}$ & 25 & 64 & 22 & 100 & 40 & 1.4 \\
\hline $\mathrm{Yb}$ & 4.0 & 7.8 & 22 & 100 & 5.2 & 1.7 \\
\hline $\mathrm{Zn}$ & 48 & 220 & 22 & 100 & 100 & 1.3 \\
\hline
\end{tabular}

Concentrations are in parts per million (ppm), unless " $(\%)$ " shown after element symbol. $\mathrm{N}=$ not detected at the lower limit of determination shown in parentheses. Mean values based on unqualified analyses only. "_-" indicates no meaningful value. Bolded maximum concentrations indicate those elements with highest ratio of maximum concentration to geometric mean value. 
Table 16

Summary statistics for 15 ashed plant samples, Chemehuevi Valley Study Area, southeastern California, USA

\begin{tabular}{|c|c|c|c|c|c|c|c|}
\hline \multirow[t]{2}{*}{ Element } & \multicolumn{2}{|c|}{ Concentration range } & \multirow{2}{*}{$\begin{array}{l}\text { Number } \\
\text { unqualified }\end{array}$} & \multirow{2}{*}{$\begin{array}{l}\text { Percent } \\
\text { unqualified }\end{array}$} & \multirow{2}{*}{$\begin{array}{l}\text { Geometric } \\
\text { Mean }\end{array}$} & \multicolumn{2}{|c|}{ Enrichment values } \\
\hline & Minimum & Maximum & & & & Plant/soil & Plant/sed \\
\hline $\mathrm{Ag}$ & $\mathrm{N}(0.10)$ & 0.89 & 5 & 33 & 0.18 & - & - \\
\hline As & 1.2 & 6.1 & 15 & 100 & 3.8 & 1.4 & 0.95 \\
\hline B & 95 & 610 & 15 & 100 & 190 & - & - \\
\hline $\mathrm{Ba}$ & 210 & 3600 & 15 & 100 & 1000 & 1.3 & 1.5 \\
\hline $\mathrm{Be}$ & 0.07 & 0.74 & 15 & 100 & 0.38 & 0.21 & - \\
\hline $\mathrm{Bi}$ & $\mathrm{N}(0.01)$ & 0.22 & 11 & 73 & 0.17 & - & - \\
\hline $\mathrm{Cd}$ & $\mathrm{N}(0.1)$ & 1.8 & 8 & 53 & 1.3 & 7.2 & 1.8 \\
\hline $\mathrm{Ce}$ & 5.5 & 53 & 15 & 100 & 26 & 0.26 & 0.24 \\
\hline $\mathrm{Co}$ & 2.3 & 10 & 15 & 100 & 6.3 & 0.57 & 0.37 \\
\hline $\mathrm{Cr}$ & 2.4 & 20 & 15 & 100 & 13 & 0.29 & 0.11 \\
\hline Cs & 0.16 & 2.7 & 15 & 100 & 1.2 & - & 0.60 \\
\hline $\mathrm{Cu}$ & 26 & 110 & 15 & 100 & 58 & 3.2 & 2.4 \\
\hline Dy & 0.23 & 2.6 & 15 & 100 & 1.37 & - & - \\
\hline $\mathrm{Er}$ & 0.12 & 1.3 & 15 & 100 & 0.73 & - & - \\
\hline $\mathrm{Eu}$ & 0.15 & 1.4 & 15 & 100 & 0.69 & 0.27 & 0.38 \\
\hline $\mathrm{Fe}(\%)$ & 0.28 & 1.30 & 15 & 100 & 0.81 & 0.23 & 0.11 \\
\hline $\mathrm{Ga}$ & 1.0 & 6.6 & 15 & 100 & 3.9 & 0.20 & - \\
\hline Gd & 0.39 & 4.5 & 15 & 100 & 2.3 & - & - \\
\hline $\mathrm{Ge}$ & 0.03 & 0.08 & 15 & 100 & 0.050 & - & - \\
\hline $\mathrm{Hf}$ & 0.04 & 0.30 & 15 & 100 & 0.17 & - & 0.0068 \\
\hline Ho & 0.042 & 0.47 & 15 & 100 & 0.25 & - & - \\
\hline In & $\mathrm{N}(0.005)$ & 0.03 & 13 & 87 & 0.020 & - & - \\
\hline $\mathrm{La}$ & 2.3 & 27 & 15 & 100 & 13 & 0.26 & 0.21 \\
\hline $\mathrm{Li}$ & 14 & 37 & 15 & 100 & 20 & 0.91 & - \\
\hline $\mathrm{Lu}$ & 0.012 & 0.14 & 15 & 100 & 0.080 & - & 0.099 \\
\hline $\operatorname{Mg}(\%)$ & 0.89 & 3.34 & 15 & 100 & 1.31 & 1.1 & 0.99 \\
\hline $\mathrm{Mn}$ & 290 & 730 & 15 & 100 & 510 & 0.85 & 0.52 \\
\hline Mo & 3.2 & 15 & 15 & 100 & 6.7 & 2.1 & 3.2 \\
\hline $\mathrm{Na}(\%)$ & 0.11 & 0.39 & 15 & 100 & 0.27 & 0.15 & 0.15 \\
\hline $\mathrm{Nb}$ & 0.07 & 0.35 & 15 & 100 & 0.15 & 0.0075 & - \\
\hline $\mathrm{Nd}$ & 2.0 & 24 & 15 & 100 & 11 & 0.25 & 0.26 \\
\hline $\mathrm{Ni}$ & 5.7 & 30 & 15 & 100 & 19 & 0.83 & 0.66 \\
\hline $\mathrm{Pb}$ & 5.3 & 33 & 15 & 100 & 19 & 1.1 & 0.90 \\
\hline $\operatorname{Pr}$ & 0.52 & 6.4 & 15 & 100 & 3.0 & - & - \\
\hline $\mathrm{Rb}$ & 11 & 35 & 15 & 100 & 26 & - & 0.43 \\
\hline $\mathrm{Re}$ & 0.004 & 0.10 & 15 & 100 & 0.010 & - & - \\
\hline $\mathrm{Se}$ & 0.46 & 2.8 & 15 & 100 & 1.0 & - & - \\
\hline $\mathrm{Sm}$ & 0.37 & 4.6 & 15 & 100 & 2.3 & - & 0.13 \\
\hline $\mathrm{Sn}$ & $\mathrm{N}(1.0)$ & 1.4 & 13 & 87 & 1.2 & - & - \\
\hline $\mathrm{Sr}$ & 550 & 2100 & 15 & 100 & 1000 & 2.9 & 2.9 \\
\hline $\mathrm{Tb}$ & 0.05 & 0.56 & 15 & 100 & 0.29 & - & 0.21 \\
\hline $\mathrm{Te}$ & $\mathrm{N}(0.10)$ & 0.19 & 6 & 40 & 0.14 & - & - \\
\hline $\mathrm{Th}$ & 0.48 & 6.3 & 15 & 100 & 2.9 & 0.19 & 0.15 \\
\hline Ti (\%) & 0.023 & 0.07 & 15 & 100 & 0.050 & 0.093 & 0.060 \\
\hline $\mathrm{Tl}$ & 0.02 & 0.24 & 15 & 100 & 0.12 & - & - \\
\hline $\mathrm{Tm}$ & 0.015 & 0.16 & 15 & 100 & 0.090 & - & - \\
\hline $\mathrm{U}$ & 0.11 & 1.2 & 15 & 100 & 0.61 & - & 0.17 \\
\hline $\mathrm{V}$ & 6.0 & 41 & 15 & 100 & 24 & 0.24 & 0.13 \\
\hline $\mathrm{Y}$ & 1.3 & 14 & 15 & 100 & 7.5 & 0.27 & 0.19 \\
\hline
\end{tabular}


Table 16 (continued)

\begin{tabular}{|c|c|c|c|c|c|c|c|}
\hline \multirow[t]{2}{*}{ Element } & \multicolumn{2}{|c|}{ Concentration range } & \multirow{2}{*}{$\begin{array}{l}\text { Number } \\
\text { unqualified }\end{array}$} & \multirow{2}{*}{$\begin{array}{l}\text { Percent } \\
\text { unqualified }\end{array}$} & \multirow{2}{*}{$\begin{array}{l}\text { Geometric } \\
\text { Mean }\end{array}$} & \multicolumn{2}{|c|}{ Enrichment values } \\
\hline & Minimum & Maximum & & & & Plant/soil & Plant/sed \\
\hline $\mathrm{Yb}$ & 0.088 & 1.0 & 15 & 100 & 0.55 & 0.18 & 0.11 \\
\hline $\mathrm{Zn}$ & 58 & 240 & 15 & 100 & 93 & 1.2 & 0.93 \\
\hline $\mathrm{Zr}$ & 1.1 & 9.7 & 15 & 100 & 5.4 & - & - \\
\hline Ash (\%) & 5.89 & 14.0 & 15 & 100 & 9.06 & - & - \\
\hline
\end{tabular}

Concentrations are in ashed weight and are in parts per million (ppm), unless "(\%)" shown after element symbol. $\mathrm{N}=$ not detected at the lower limit of determination shown in parentheses. Mean values based on unqualified analyses only. "_," indicates no meaningful value. Bolded maximum concentrations indicate those elements with highest ratio of maximum concentration to geometric mean value.

Plants: Six species (Chsp, Fosp, Losa, Plov, Scsp, Spam; Appendix 1) were collected and analysed using dry, non-ashed material. A comparison of geometric mean values for elements in non-ashed plants collected for the entire region (Table 3) and those collected in the Chuckwalla area (Table 19) indicates that Chuckwalla Bench plants are relatively enriched $(1.3 \times$ to $2.3 \times)$ in 12 elements $(\mathrm{Ce}, \mathrm{Cr}, \mathrm{Fe}, \mathrm{Hf}, \mathrm{La}, \mathrm{Lu}, \mathrm{Sc}, \mathrm{Sm}, \mathrm{Th}, \mathrm{U}, \mathrm{Yb}$, and possibly Au) (Plant/plant column, Table 19).

A comparison of geometric mean values in the Chuckwalla Bench area plants (Table 19) (multiplied by 10) with those for soils and sediments (Tables 17 and 18) from this study area suggests that, for elements determined in all three data sets, plants are relatively enriched $(>1.4 \times)$ in six elements $(\mathrm{Ca}, \mathrm{K}, \mathrm{Mo}, \mathrm{Sr}, \mathrm{Zn}$; possibly $\mathrm{Au})$ as compared to soils (Plant/soil column, Table 19) and to sediments (Plant/sed column, Table 19). Concentrations for most other elements are significantly lower in plants.

\subsection{Chemistry of plants by taxa}

The chemistry of plant taxa consumed by tortoises will determine in part which elements are ingested by tortoises. The overall chemistry of a given plant species is dependent on a number of parameters, including genetics, plant part (stem, leaf, flower, fruit), soil type, availability of elements in the soil substrate, depth of roots, phenological stage, seasonal temperatures and rainfall, effects of livestock, proximity to roads or other man-made features, elevation, aspect, topography, and probably other factors. In addition, surfaces of plant parts can be contaminated by dust from various sources. Plants that have pubescent or glandular surfaces (Footnote 2, Appendix 1) will tend to accumulate more surface contaminants than those that do not. Leaves and other plant parts nearest the soil surface, especially those of prostrate species, such as members of the spurge genus, Chamaesyce, will tend to accumulate more contaminants than parts that grow farther from the surface.

Table 20 lists those elements that have relatively high or low concentrations based on geometric mean values for a given taxa when compared to the two regional data bases for plants. These comparative data must be considered qualitative at best for several reasons. The number of samples for many species is small. Analyses for some elements were limited and did not include all samples. Also, none of the samples was washed. Consequently, we do not know how much of the concentration of a given element in a sample is systemic and 
Table 17

Summary statistics for 5 soil samples, Chuckwalla Bench Study Area, southeastern California, USA

\begin{tabular}{|c|c|c|c|c|c|c|c|}
\hline \multirow[t]{2}{*}{ Element } & \multicolumn{2}{|c|}{ Concentration range } & \multirow{2}{*}{$\begin{array}{l}\text { Number } \\
\text { unqualified }\end{array}$} & \multirow{2}{*}{$\begin{array}{l}\text { Percent } \\
\text { unqualified }\end{array}$} & \multirow{2}{*}{$\begin{array}{l}\text { Geometric } \\
\text { mean }\end{array}$} & \multicolumn{2}{|c|}{ Enrichment values } \\
\hline & Minimum & Maximum & & & & Soil/soil & Soil/sed \\
\hline $\mathrm{Al}(\%)$ & 6.08 & 6.46 & 5 & 100 & 6.23 & 0.84 & 1.1 \\
\hline As & 3.0 & 7.0 & 5 & 100 & 4.4 & 0.59 & 0.44 \\
\hline $\mathrm{Au}(\mathrm{ppb})$ & $\mathrm{N}(0.10)$ & 0.20 & 3 & 60 & 0.13 & 0.19 & 0.022 \\
\hline $\mathrm{Ba}$ & 550 & 650 & 5 & 100 & 600 & 0.81 & 1.2 \\
\hline $\mathrm{Be}$ & 2.0 & 3.0 & 5 & 100 & 2.2 & 1.0 & - \\
\hline $\mathrm{Ca}(\%)$ & 3.08 & 4.81 & 5 & 100 & 3.96 & 1.5 & 1.3 \\
\hline $\mathrm{Cd}$ & 0.14 & 0.17 & 5 & 100 & 0.16 & 1.1 & - \\
\hline $\mathrm{Ce}$ & 110 & 170 & 5 & 100 & 140 & 1.4 & 1.4 \\
\hline $\mathrm{Co}$ & 11 & 12 & 5 & 100 & 11 & 1.1 & 1.1 \\
\hline $\mathrm{Cr}$ & 45 & 56 & 5 & 100 & 49 & 1.4 & 1.1 \\
\hline $\mathrm{Cu}$ & 13 & 19 & 5 & 100 & 16 & 0.84 & 0.76 \\
\hline $\mathrm{Fe}(\%)$ & 2.99 & 3.37 & 5 & 100 & 3.21 & 0.84 & 0.62 \\
\hline $\mathrm{Ga}$ & 11 & 29 & 5 & 100 & 21 & 1.1 & - \\
\hline K $(\%)$ & 1.94 & 2.07 & 5 & 100 & 2.01 & 0.91 & 1.1 \\
\hline $\mathrm{La}$ & 60 & 93 & 5 & 100 & 78 & 1.5 & 0.52 \\
\hline $\mathrm{Li}$ & 31 & 35 & 5 & 100 & 33 & 1.1 & - \\
\hline $\operatorname{Mg}(\%)$ & 1.14 & 1.32 & 5 & 100 & 1.24 & 1.1 & 1.2 \\
\hline $\mathrm{Mn}$ & 550 & 710 & 5 & 100 & 650 & 0.96 & 0.59 \\
\hline Mo & 3.0 & 5.0 & 5 & 100 & 3.5 & 1.0 & 0.97 \\
\hline $\mathrm{Na}(\%)$ & 1.33 & 1.65 & 5 & 100 & 1.47 & 0.77 & 0.91 \\
\hline $\mathrm{Nb}$ & 22 & 39 & 5 & 100 & 31 & 1.2 & - \\
\hline $\mathrm{Nd}$ & 41 & 62 & 5 & 100 & 50 & 1.1 & 0.72 \\
\hline $\mathrm{Ni}$ & 18 & 22 & 5 & 100 & 20 & 1.0 & 1.3 \\
\hline $\mathrm{P}(\%)$ & 0.065 & 0.11 & 5 & 100 & 0.082 & 0.91 & 1.3 \\
\hline $\mathrm{Pb}$ & 10 & 15 & 5 & 100 & 13 & 0.76 & 0.57 \\
\hline $\mathrm{Sc}$ & 11 & 12 & 5 & 100 & 11 & 0.92 & 0.92 \\
\hline $\mathrm{Sr}$ & 230 & 280 & 5 & 100 & 250 & 0.74 & 1.1 \\
\hline $\mathrm{Th}$ & 22 & 41 & 5 & 100 & 29 & 1.7 & 0.45 \\
\hline $\mathrm{Ti}(\%)$ & 0.54 & 0.78 & 5 & 100 & 0.66 & 1.2 & 0.66 \\
\hline $\mathrm{V}$ & 79 & 88 & 5 & 100 & 83 & 0.88 & 0.83 \\
\hline $\mathrm{Y}$ & 24 & 30 & 5 & 100 & 28 & 1.0 & 0.68 \\
\hline $\mathrm{Yb}$ & 3.0 & 3.0 & 5 & 100 & 3.0 & 1.0 & 0.43 \\
\hline $\mathrm{Zn}$ & 75 & 79 & 5 & 100 & 78 & 1.0 & 0.86 \\
\hline
\end{tabular}

Concentrations are in parts per million (ppm), unless "(\%)" or "ppb" (parts per billion) shown after element symbol. $\mathrm{N}=$ not detected at the lower limit of determination shown in parentheses. Mean values based on unqualified analyses only. "_," indicates no meaningful value. Bolded maximum concentration indicates that element with highest ratio of maximum concentration to geometric mean value.

how much is surface contamination. We suspect that high concentrations of non-essential elements are largely contamination, particularly if a suite of such elements was found.

Plant species (with elements in parentheses) that exhibited unusually high concentrations that are not readily explained by either common element associations or contamination include Amte (Ba), Brsp (Cr), Cacl (Na), Dita (Re), Lusp (Cr, Na, Rb), Opba (Re), and Plri (Re). None of these elements is considered to be essential to plant metabolism (Lepp, 1981). 
Table 18

Summary statistics for 14 stream sediment samples, Chuckwalla Bench Study Area, southeastern California, USA

\begin{tabular}{|c|c|c|c|c|c|c|}
\hline \multirow[t]{2}{*}{ Element } & Concentra & & \multirow{2}{*}{$\begin{array}{l}\text { Number } \\
\text { unqualified }\end{array}$} & \multirow{2}{*}{$\begin{array}{l}\text { Percent } \\
\text { unqualified }\end{array}$} & \multirow{2}{*}{$\begin{array}{l}\text { Geometric } \\
\text { mean }\end{array}$} & \multirow{2}{*}{$\begin{array}{l}\text { Enrichment } \\
\text { value }\end{array}$} \\
\hline & Minimum & Maximum & & & & \\
\hline
\end{tabular}

\begin{tabular}{|c|c|c|c|c|c|c|}
\hline $\mathrm{Al}(\%)$ & 4.68 & 6.37 & 14 & 100 & 5.50 & 0.91 \\
\hline As & 6.5 & 25 & 14 & 100 & 10 & 2.3 \\
\hline $\mathrm{Au}(\mathrm{ppb})$ & $\mathrm{N}(2.0)$ & 8.0 & 5 & 36 & 5.9 & 45 \\
\hline $\mathrm{Ba}$ & 330 & 640 & 14 & 100 & 510 & 0.83 \\
\hline $\mathrm{Be}$ & $\mathrm{N}(2.0)$ & 2.0 & 6 & 43 & - & - \\
\hline $\mathrm{Ca}(\%)$ & 2.52 & 3.84 & 14 & 100 & 3.07 & 0.77 \\
\hline $\mathrm{Cd}$ & $\mathrm{N}(0.5)$ & 0.50 & 3 & 21 & - & - \\
\hline $\mathrm{Ce}$ & 150 & 400 & 14 & 100 & 230 & 0.71 \\
\hline $\mathrm{Co}$ & 8 & 14 & 14 & 100 & 10 & 0.91 \\
\hline $\mathrm{Cr}$ & 21 & 68 & 14 & 100 & 43 & 0.91 \\
\hline Cs & 2.0 & 5.0 & 14 & 100 & 3.0 & - \\
\hline $\mathrm{Cu}$ & 16 & 28 & 14 & 100 & 21 & 1.3 \\
\hline $\mathrm{Eu}$ & 1.0 & 2.6 & 14 & 100 & 1.7 & - \\
\hline $\mathrm{Fe}(\%)$ & 3.12 & 9.47 & 14 & 100 & 5.19 & 1.6 \\
\hline Hf & 31 & 100 & 14 & 100 & 53 & - \\
\hline K (\%) & 1.64 & 2.19 & 14 & 100 & 1.89 & 0.91 \\
\hline $\mathrm{La}$ & 88 & 250 & 14 & 100 & 150 & 1.9 \\
\hline $\mathrm{Lu}$ & 0.69 & 2.0 & 14 & 100 & 1.1 & - \\
\hline $\operatorname{Mg}(\%)$ & 0.81 & 1.26 & 14 & 100 & 1.00 & 0.83 \\
\hline $\mathrm{Mn}$ & 830 & 1600 & 14 & 100 & 1100 & 1.7 \\
\hline Mo & $\mathrm{N}(2.0)$ & 11 & 4 & 29 & 3.6 & 1.0 \\
\hline $\mathrm{Na}(\%)$ & 1.27 & 2.12 & 14 & 100 & 1.62 & 1.1 \\
\hline $\mathrm{Nd}$ & 49 & 120 & 14 & 100 & 69 & 1.4 \\
\hline $\mathrm{Ni}$ & 11 & 70 & 14 & 100 & 16 & 0.77 \\
\hline P (\%) & 0.035 & 0.12 & 14 & 100 & 0.062 & 0.77 \\
\hline $\mathrm{Pb}$ & 10 & 31 & 14 & 100 & 23 & 1.8 \\
\hline $\mathrm{Rb}$ & $\mathrm{N}(15)$ & 120 & 11 & 79 & 62 & - \\
\hline $\mathrm{Sb}$ & 0.80 & 2.3 & 14 & 100 & 1.2 & - \\
\hline $\mathrm{Sc}$ & 9.7 & 15 & 14 & 100 & 12 & 1.1 \\
\hline $\mathrm{Sm}$ & 8.9 & 21 & 14 & 100 & 12 & - \\
\hline $\mathrm{Sr}$ & 210 & 280 & 14 & 100 & 230 & 0.91 \\
\hline $\mathrm{Ta}$ & $\mathrm{N}(0.5)$ & 9.1 & 13 & 93 & 3.6 & - \\
\hline $\mathrm{Tb}$ & $\mathrm{N}(0.5)$ & 3.8 & 8 & 57 & 1.7 & - \\
\hline Th & 29 & 140 & 14 & 100 & 64 & 2.2 \\
\hline $\mathrm{Ti}(\%)$ & 0.56 & 1.7 & 14 & 100 & 1.0 & 1.7 \\
\hline $\mathrm{U}$ & 4.5 & 29 & 14 & 100 & 11 & - \\
\hline $\mathrm{V}$ & 75 & 170 & 14 & 100 & 100 & 1.2 \\
\hline W & $\mathrm{N}(1.0)$ & 13 & 2 & 14 & - & - \\
\hline $\mathrm{Y}$ & 27 & 68 & 14 & 100 & 41 & 1.5 \\
\hline $\mathrm{Yb}$ & 4.3 & 11 & 14 & 100 & 6.9 & 2.3 \\
\hline $\mathrm{Zn}$ & 79 & 110 & 14 & 100 & 91 & 1.2 \\
\hline
\end{tabular}

Concentrations are in parts per million (ppm), unless "(\%)" or "ppb" (parts per billion) shown after element symbol. $\mathrm{N}=$ not detected at the lower limit of determination shown in parentheses. Mean values based on unqualified analyses only. "_," in geometric mean column indicates no meaningful value. Bolded maximum concentrations indicate those elements with highest ratio of maximum concentration to geometric mean value. 
Table 19

Summary statistics for 14 non-ashed plant samples, Chuckwalla Bench Study Area, southeastern California, USA

\begin{tabular}{|c|c|c|c|c|c|c|c|c|}
\hline \multirow[t]{2}{*}{ Element } & \multicolumn{2}{|c|}{ Concentration range } & \multirow{2}{*}{$\begin{array}{l}\text { Number } \\
\text { unqualified }\end{array}$} & \multirow{2}{*}{$\begin{array}{l}\text { Percent } \\
\text { unqualified }\end{array}$} & \multirow{2}{*}{$\begin{array}{l}\text { Geometric } \\
\text { mean }\end{array}$} & \multicolumn{3}{|c|}{ Enrichment values } \\
\hline & Minimum & Maximum & & & & Plant/plant & Plant/soil & Plant/sed \\
\hline As & 0.01 & 1.3 & 14 & 100 & 0.36 & 0.59 & 0.82 & 0.36 \\
\hline $\mathrm{Au}(\mathrm{ppb})$ & 2.0 & 32 & 14 & 100 & 5.8 & 2.3 & 450 & 9.8 \\
\hline $\mathrm{Ba}$ & 12 & 140 & 14 & 100 & 48 & 1.1 & 0.80 & 0.94 \\
\hline $\mathrm{Br}$ & 3.9 & 36 & 14 & 100 & 14 & 0.60 & - & - \\
\hline $\mathrm{Ca}(\%)$ & 0.32 & 4.80 & 14 & 100 & 1.20 & 0.67 & 3.0 & 3.9 \\
\hline $\mathrm{Ce}$ & 0.40 & 7.4 & 14 & 100 & 1.6 & 1.9 & 0.11 & 0.070 \\
\hline $\mathrm{Co}$ & 0.30 & 1.2 & 14 & 100 & 0.52 & 1.1 & 0.47 & 0.52 \\
\hline $\mathrm{Cr}$ & 0.10 & 6.9 & 14 & 100 & 1.8 & 1.3 & 0.37 & 0.42 \\
\hline $\mathrm{Cs}$ & 0.01 & 0.35 & 14 & 100 & 0.086 & 1.1 & - & 0.29 \\
\hline $\mathrm{Eu}$ & $\mathrm{N}(0.05)$ & 0.11 & 4 & 29 & - & - & - & - \\
\hline $\mathrm{Fe}(\%)$ & 0.015 & 0.23 & 14 & 100 & 0.062 & 1.5 & 0.19 & 0.12 \\
\hline Hf & 0.06 & 1.3 & 14 & 100 & 0.26 & 2.0 & - & 0.049 \\
\hline Ir & $\mathrm{N}(0.10)$ & 0.5 & 1 & 7 & - & - & - & - \\
\hline K (\%) & 0.56 & 2.80 & 14 & 100 & 1.32 & 0.50 & 6.6 & 7.0 \\
\hline $\mathrm{La}$ & 0.15 & 4.3 & 14 & 100 & 0.87 & 1.6 & 0.11 & 0.058 \\
\hline $\mathrm{Lu}$ & 0.003 & 0.044 & 14 & 100 & 0.010 & 1.4 & - & 0.091 \\
\hline Mo & 0.29 & 2.0 & 14 & 100 & 0.57 & 0.71 & 1.6 & 1.6 \\
\hline $\mathrm{Na}(\%)$ & 0.013 & 0.16 & 14 & 100 & 0.046 & 0.92 & 0.30 & 0.28 \\
\hline $\mathrm{Nd}$ & $\mathrm{N}(0.5)$ & 2.7 & 8 & 57 & 1.0 & 1.0 & 0.20 & 0.14 \\
\hline $\mathrm{Rb}$ & $\mathrm{N}(2.0)$ & 10 & $13^{\mathrm{b}}$ & $100^{\mathrm{b}}$ & 5.1 & 0.70 & - & 0.82 \\
\hline $\mathrm{Sb}$ & 0.003 & 0.16 & 14 & 100 & 0.04 & 0.80 & - & 0.33 \\
\hline $\mathrm{Sc}$ & 0.03 & 0.77 & 14 & 100 & 0.18 & 1.5 & 0.16 & 0.15 \\
\hline $\mathrm{Se}$ & $\mathrm{N}(0.10)$ & 0.90 & 5 & 36 & 0.42 & 1.0 & - & - \\
\hline $\mathrm{Sm}$ & 0.01 & 0.49 & 14 & 100 & 0.10 & 1.7 & - & 0.083 \\
\hline $\mathrm{Sr}$ & 27 & 200 & 14 & 100 & 87 & 0.73 & 3.5 & 3.8 \\
\hline $\mathrm{Ta}$ & $\mathrm{N}(0.05)$ & 0.10 & 3 & 21 & - & - & - & - \\
\hline $\mathrm{Th}$ & 0.03 & 0.30 & 14 & 100 & 0.26 & 1.5 & 0.090 & 0.041 \\
\hline $\mathrm{U}$ & $\mathrm{N}(0.003)^{\mathrm{a}}$ & 0.25 & 13 & 93 & 0.06 & 2.0 & - & 0.055 \\
\hline $\mathrm{W}$ & $\mathrm{N}(0.01)^{\mathrm{a}}$ & 0.55 & 5 & 36 & 0.04 & 0.18 & - & - \\
\hline $\mathrm{Yb}$ & 0.018 & 0.33 & 14 & 100 & 0.07 & 1.8 & 0.23 & 0.10 \\
\hline $\mathrm{Zn}$ & 9.0 & 20 & 14 & 100 & 13 & 0.87 & 1.7 & 1.4 \\
\hline
\end{tabular}

Concentrations are in dry weight and are in parts per million (ppm), unless "(\%)" or "ppb" (parts per billion) shown after element symbol. $\mathrm{N}=$ not detected at the lower limit of determination shown in parentheses. Mean values based on unqualified analyses only. "_," indicates no meaningful value. Bolded maximum concentrations indicate those elements with highest ratio of maximum concentration to geometric mean value.

a Element has more than one lower limit of determination. Lowest value shown.

${ }^{\mathrm{b}}$ Element not determined for all samples. Percent based on actual number of samples analysed.

\section{Results: distributions and potential sources of selected anomalous elements}

The accompanying maps for the Western Mojave and Goldstone Study Areas (Figs. 4-8) show sites with anomalous concentrations above a selected threshold concentration. Because of the wide range of reported concentrations for many elements in the overall Western Mojave Study Area, the threshold concentration selected for the figures included for that area are $\sim 2 \times$ the regional geometric mean value after taking into account the number of analyses reported as being below the lower limit of determination. 
Table 20

Summary of element anomalies in plants, by species, for six study areas, southeastern California, USA

\begin{tabular}{|c|c|c|c|c|c|}
\hline Species name & $\begin{array}{l}\text { No. sites/ } \\
\text { samples }\end{array}$ & Symbol & Areas & $\begin{array}{l}\text { Elements with } \\
\text { concentrations above } \\
\text { regional geometric mean } \\
\text { value }\end{array}$ & $\begin{array}{l}\text { Elements with } \\
\text { concentrations below } \\
\text { regional geometric mean } \\
\text { value }\end{array}$ \\
\hline $\begin{array}{l}\text { Achnatherum } \\
\text { hymenoides }\end{array}$ & $19 / 20$ & Achy & WM-N/S;GS & None & $\begin{array}{l}\mathrm{Ba}^{*}, \mathrm{Br}, \mathrm{Ca}^{*}, \mathrm{Cd}^{*}, \mathrm{Co}^{*}, \\
\mathrm{Cs}^{*}, \mathrm{Fe}^{*}, \mathrm{Hf}^{*}, \mathrm{~K}, \mathrm{La}^{*}, \\
\mathrm{Lu}^{*}, \mathrm{Na}^{* *}, \mathrm{Rb}^{*}, \mathrm{Sc}^{*}, \\
\mathrm{Sm}^{*}, \mathrm{Sr}^{* *}, \mathrm{Th}^{* *}, \mathrm{U}^{*}, \\
\mathrm{~W}^{*}, \mathrm{Yb}^{* *}\end{array}$ \\
\hline $\begin{array}{l}\text { Achnatherum } \\
\text { speciosum }\end{array}$ & $4 / 5$ & Acsp & WM-N & $\mathrm{W}^{*}$ & $\begin{array}{l}\mathrm{Ba}^{*}, \mathrm{Br}, \mathrm{Ca}^{*}, \mathrm{Co}, \mathrm{K}^{*}, \mathrm{La}, \\
\mathrm{Lu}, \mathrm{Mo}, \mathrm{Na}^{*}, \mathrm{Rb}^{*}, \mathrm{Sm}, \\
\mathrm{Sr} *\end{array}$ \\
\hline $\begin{array}{l}\text { Amsinckia } \\
\text { tessellata }\end{array}$ & $1 / 1$ & Amte & WM-N & $\mathrm{Ba}^{* *}, \mathrm{Ca}^{*}, \mathrm{Ce}, \mathrm{Sr}$ & $\begin{array}{l}\mathrm{As}^{*}, \mathrm{Cr}^{* *}, \mathrm{Cs}^{* *}, \mathrm{Fe}^{* *}, \\
\mathrm{La}, \mathrm{Mo}^{*}, \mathrm{Na}^{*}, \mathrm{Sb}^{* *}, \mathrm{Sc}^{*}, \\
\mathrm{Sm}^{*}, \mathrm{Th}^{* *}, \mathrm{U}^{* *}, \mathrm{~W}^{*}, \\
\mathrm{Yb}^{* *}\end{array}$ \\
\hline $\begin{array}{l}\text { Astragalus } \\
\text { acutirostris }\end{array}$ & $1 / 1$ & Asac & WM-N & $\begin{array}{l}\mathrm{As}^{* *}, \mathrm{Ce}, \mathrm{K}, \mathrm{Rb}^{*}, \mathrm{Sb}^{* *} \\
\mathrm{~W}, \mathrm{Zn}\end{array}$ & $\begin{array}{l}\mathrm{Ba}^{*}, \mathrm{Br}^{*}, \mathrm{Co}^{*}, \mathrm{Cr}^{*}, \mathrm{La}^{*}, \\
\mathrm{Lu}, \mathrm{Sc}^{*}, \mathrm{Sm}^{*}, \mathrm{Sr}^{*}, \mathrm{Th}^{* *}, \\
\mathrm{U}^{* *}, \mathrm{Yb}^{*}\end{array}$ \\
\hline $\begin{array}{l}\text { Astragalus } \\
\text { didymocarpus }\end{array}$ & $3 / 3$ & Asdi & WM-N/S & None & $\begin{array}{l}\mathrm{Ba}^{*}, \mathrm{Br}^{*}, \mathrm{Co}, \mathrm{Cr}^{* *}, \mathrm{Cs}^{*}, \\
\mathrm{Fe}^{*}, \mathrm{Hf}^{*}, \mathrm{La}^{*}, \mathrm{Lu}^{*}, \\
\mathrm{Mo}^{* *}, \mathrm{Na}^{*}, \mathrm{Sc}^{*}, \mathrm{Sm}^{* *}, \\
\mathrm{Th}^{* *}, \mathrm{U}^{* *}, \mathrm{~W}, \mathrm{Yb}^{*}\end{array}$ \\
\hline $\begin{array}{l}\text { Astragalus } \\
\text { layneae }\end{array}$ & $19 / 19$ & Asla & WM-N/S;GS & $\begin{array}{l}\mathrm{Ca}, \mathrm{Cd}, \mathrm{Cs}, \mathrm{Fe}, \mathrm{K}, \mathrm{Na}^{*}, \\
\mathrm{Rb}^{*}, \mathrm{Sc}, \mathrm{Sr}, \mathrm{W}\end{array}$ & $\mathrm{Ce}^{*}$ \\
\hline $\begin{array}{l}\text { Astragalus } \\
\text { lentiginosus }\end{array}$ & $3 / 3$ & Asle & WM-S;GS & $\mathrm{W}^{*}$ & $\mathrm{As}, \mathrm{Ba}, \mathrm{Br}, \mathrm{Co}, \mathrm{Lu}, \mathrm{Na}$ \\
\hline $\begin{array}{l}\text { Astragalus } \\
\text { species }\end{array}$ & $3 / 3$ & Assp & GS & $\begin{array}{l}\mathrm{Fe}, \mathrm{Hf}, \mathrm{K}, \mathrm{La}, \mathrm{Rb}^{*}, \mathrm{Sc}^{*} \text {, } \\
\mathrm{Sm}, \mathrm{W}^{*}\end{array}$ & None \\
\hline Bromus species & $1 / 1$ & Brsp & GS & $\begin{array}{l}\mathrm{As}^{* *}, \mathrm{Cr}^{* *}, \mathrm{Fe}, \mathrm{Mo}, \mathrm{Na} \\
\mathrm{Sb}^{*}, \mathrm{Sc}, \mathrm{U}^{*}\end{array}$ & $\mathrm{Br}^{* *}, \mathrm{Ca}^{*}, \mathrm{Nd}, \mathrm{Rb}^{*}, \mathrm{Sr}^{*}$ \\
\hline $\begin{array}{l}\text { Camissonia } \\
\text { boothii }\end{array}$ & $12 / 12$ & Cabo & WM-N/S;GS & $\mathrm{As}^{*}, \mathrm{Ca}^{*}, \mathrm{Mo}, \mathrm{Na}, \mathrm{Sr}^{*}$ & $\mathrm{Th}, \mathrm{U}^{*}, \mathrm{~W}, \mathrm{Yb}$ \\
\hline $\begin{array}{l}\text { Camissonia } \\
\text { claviformis }\end{array}$ & $5 / 5$ & Cacl & GS & $\mathrm{Br}^{*}, \mathrm{~K}, \mathrm{Na} * *$ & $\begin{array}{l}\mathrm{Cd}, \mathrm{Co}, \mathrm{Cr}, \mathrm{Fe}, \mathrm{La}, \mathrm{Lu}^{*}, \\
\mathrm{Mo}^{*}, \mathrm{Sb}^{* *}, \mathrm{Sc}, \mathrm{Sm}^{*}, \mathrm{Th}, \\
\mathrm{W}, \mathrm{Yb}\end{array}$ \\
\hline $\begin{array}{l}\text { Chamaesyce } \\
\text { species-WM }\end{array}$ & $9 / 9$ & Chwm & WM-N & $\mathrm{As}, \mathrm{Ce}, \mathrm{Cs}, \mathrm{Sb}^{*}, \mathrm{Zn}$ & $\mathrm{K}, \mathrm{Rb}, \mathrm{Sr}$ \\
\hline $\begin{array}{l}\text { Chamaesyce } \\
\text { species-CM }\end{array}$ & $6 / 6$ & Chem & GS & $\begin{array}{l}\mathrm{Ce}, \mathrm{Co}, \mathrm{Cr} *, \mathrm{Fe}^{*}, \mathrm{Hf}, \\
\mathrm{La}, \mathrm{Lu}, \mathrm{Na}, \mathrm{Sc}^{*}, \mathrm{Sm}, \mathrm{Th}, \\
\mathrm{U}^{* *}, \mathrm{Yb}^{*}, \mathrm{Zn}^{*}\end{array}$ & $\mathrm{Br}, \mathrm{Cd}, \mathrm{Se}, \mathrm{Sr}$ \\
\hline $\begin{array}{l}\text { Chamaesyce } \\
\text { species-EM }\end{array}$ & $9 / 12$ & Chem & GF & $\begin{array}{l}A l, B^{*}, C u^{*}, K^{*}, I n, L i^{*} \\
M o^{*}, N a, N b^{*}, S b, S c, S i \\
S r, T i, Z n^{*}\end{array}$ & $\begin{array}{l}\mathrm{As}^{* *}, \mathrm{Ba}, \mathrm{Br}, \mathrm{Ca}^{*}, \mathrm{Cr} \\
\mathrm{Fe}, \mathrm{K}^{*}, \mathrm{Lu}, \mathrm{Mo}^{* *}, \mathrm{Na}^{*}, \\
\mathrm{Rb}^{*}, \mathrm{Sb}^{* *}, \mathrm{Sc}, \mathrm{Sr}^{*}\end{array}$ \\
\hline $\begin{array}{l}\text { Chamsaesyce } \\
\text { species-EC }\end{array}$ & $4 / 4$ & Chec & $\mathrm{CK}$ & $\begin{array}{l}\mathrm{Ce}, \mathrm{Cr}, \mathrm{Fe}, \mathrm{Hf}, \mathrm{La}, \mathrm{Sc} \\
\mathrm{Sm}, \mathrm{Th}, \mathrm{U}^{*}, \mathrm{Yb}\end{array}$ & $\mathrm{Br}, \mathrm{K}^{*}, \mathrm{Nd}, \mathrm{Rb}, \mathrm{Se}, \mathrm{W}$ \\
\hline $\begin{array}{l}\text { Chorizanthe } \\
\text { brevicornu }\end{array}$ & $2 / 2$ & Chbr & $\mathrm{WM}-\mathrm{N} / \mathrm{S}$ & $\begin{array}{l}\text { No.: As**, Ba, Br*, Co, } \\
\text { Sb**; So.: Br }\end{array}$ & $\begin{array}{l}\text { No.: } \mathrm{Ca}, \mathrm{Cd}, \mathrm{Cr}^{* *}, \mathrm{Hf}^{* *}, \\
\mathrm{La}, \mathrm{Sm}^{*}, \mathrm{Sr}^{* *}, \mathrm{Th}^{* *}, \\
\mathrm{U}^{* *}, \mathrm{So} .: \mathrm{As}^{* *}, \mathrm{Ca}^{*}, \mathrm{Ce}, \\
\mathrm{Cr}^{*}, \mathrm{Cs}^{* *}, \mathrm{Fe}, \mathrm{Hf}^{* *}, \mathrm{La}^{*}, \\
\mathrm{Lu}^{*}, \mathrm{Mo}^{* *}, \mathrm{Sb}^{*}, \mathrm{Sc}^{*}, \\
\mathrm{Sm}^{* *}, \mathrm{Sr}^{*}, \mathrm{Th}^{* *}, \mathrm{U}^{* *}, \\
\mathrm{~W}^{* *}\end{array}$ \\
\hline $\begin{array}{l}\text { Chorizanthe } \\
\text { species }\end{array}$ & $1 / 1$ & Chsp & CK & None & $\begin{array}{l}\mathrm{As}^{* *}, \mathrm{Ba}, \mathrm{Br}^{* *}, \mathrm{Ca}^{*}, \\
\mathrm{Ce}^{*}, \mathrm{Cr}^{*}, \mathrm{Cs}^{* *}, \mathrm{Fe}^{*}, \\
\mathrm{Hf}^{* *}, \mathrm{La}^{*}, \mathrm{Lu}^{*}, \mathrm{Mo}^{*}, \\
\mathrm{Na}, \mathrm{Sb}^{*}, \mathrm{Sc}^{* *}, \mathrm{Sm}^{*}, \mathrm{Sr}^{*}, \\
\mathrm{Th}^{* *}, \mathrm{U}^{* *}, \mathrm{~W}^{* *}, \mathrm{Yb}\end{array}$ \\
\hline
\end{tabular}


Table 20 (continued)

\begin{tabular}{|c|c|c|c|c|c|}
\hline Species name & $\begin{array}{l}\text { No. sites/ } \\
\text { samples }\end{array}$ & Symbol & Areas & $\begin{array}{l}\text { Elements with } \\
\text { concentrations above } \\
\text { regional geometric mean } \\
\text { value }\end{array}$ & $\begin{array}{l}\text { Elements with } \\
\text { concentrations below } \\
\text { regional geometric mean } \\
\text { value }\end{array}$ \\
\hline Ditaxis species & $1 / 1$ & Dita & GF & $\begin{array}{l}\mathrm{Br} * \mathrm{Cd}, \mathrm{Co} *, \mathrm{Fe}, \mathrm{Hf}, \\
\mathrm{La}^{* *}, \mathrm{Sm}^{*}, \mathrm{Yb}, A l, B e, \\
\mathrm{In}^{*}, \mathrm{Li}^{*}, M g^{*}, R e^{* *}, S b^{*}, \\
S c, S e^{*}, S r\end{array}$ & $\begin{array}{l}\mathrm{As}^{* *}, \mathrm{Mo}^{* *}, \mathrm{Nd}, \mathrm{Sb}^{*}, \\
\mathrm{Sr}^{*}, \mathrm{U}^{*}, \mathrm{~W}^{* *}, \mathrm{Zn}^{*}, A s, \\
B r^{*}, C s^{*}, I^{*}, M o, U, Z r^{* *}\end{array}$ \\
\hline $\begin{array}{l}\text { Erodium } \\
\text { cicutarium }\end{array}$ & $49 / 49$ & Erci & WM-N/S;GS & $\begin{array}{l}\mathrm{As}^{*}, \mathrm{Ba}, \mathrm{Br}, \mathrm{Ca}, \mathrm{Cd}, \mathrm{Ce}^{*}, \\
\mathrm{Cs}, \mathrm{Fe}, \mathrm{Hf}, \mathrm{La}, \mathrm{Mo}, \mathrm{Sb}^{*} \\
\mathrm{Sc}^{*}, \mathrm{Sm}, \mathrm{Sr}, \mathrm{Th}, \mathrm{W}, \mathrm{Yb}\end{array}$ & $\mathrm{Se}$ \\
\hline $\begin{array}{l}\text { Fouquieria } \\
\text { splendens }\end{array}$ & $1 / 1$ & Fosp & CK & $\mathrm{Cr}^{*}, \mathrm{Cs}^{*}, \mathrm{Sb}^{*}$ & $\begin{array}{l}\mathrm{As}^{*}, \mathrm{Ba}^{*}, \mathrm{Br}^{*}, \mathrm{Ca}^{*}, \mathrm{Co}, \\
\mathrm{K}, \mathrm{Lu}, \mathrm{Mo}, \mathrm{Na}, \mathrm{Nd}^{*} \\
\mathrm{Sb}^{* *}, \mathrm{Sr}^{*}, \mathrm{Th}, \mathrm{U}^{*}\end{array}$ \\
\hline $\begin{array}{l}\text { Lotus } \\
\text { humistratus }\end{array}$ & $2 / 2$ & Lohu & WM-N/S & $\begin{array}{l}\text { No.: } \mathrm{Ca}^{*}, \mathrm{Ce}, \mathrm{K}, \mathrm{Rb}, \\
\mathrm{Sb}^{* *}, \mathrm{~W}^{*} ; \mathrm{So} .: \mathrm{Ca}^{*}, \mathrm{Ce}, \\
\mathrm{K}, \mathrm{La}^{*}, \mathrm{Sr}^{*}, \mathrm{~W}\end{array}$ & $\begin{array}{l}\text { No.: } \mathrm{As}^{* *}, \mathrm{Br}^{* *}, \mathrm{Co}, \\
\mathrm{Mo}^{*}, \mathrm{Na}^{*}, \mathrm{Nd}, \mathrm{Th}, \mathrm{U}^{*} ; \\
\text { So.: } \mathrm{As}^{*}, \mathrm{Ba}^{*}, \mathrm{Cr}^{* *}, \\
\mathrm{Cs}^{* *}, \mathrm{Fe}^{*}, \mathrm{Hf}^{* *}, \mathrm{Mo}, \\
\mathrm{Na}^{*}, \mathrm{Nd}^{*}, \mathrm{Sb}^{* *}, \mathrm{Sc}^{*}, \\
\text { Th*}, \mathrm{U}^{*}\end{array}$ \\
\hline $\begin{array}{l}\text { Lotus } \\
\text { salsuginosus } \\
\text { var. } \\
\text { brevivexillus }\end{array}$ & $3 / 3$ & Losa & CK & $\mathrm{Ca}, \mathrm{Ce}, \mathrm{Rb}, \mathrm{Sr}^{*}, \mathrm{Th}$ & $\begin{array}{l}\mathrm{Br}^{*}, \mathrm{Cr}^{*}, \mathrm{Cs}^{*}, \mathrm{Sb}^{*}, \mathrm{~W}^{* *}, \\
\mathrm{Zn}\end{array}$ \\
\hline $\begin{array}{l}\text { Lotus } \\
\text { tomentellus }\end{array}$ & $2 / 2$ & Loto & WM-N & $\begin{array}{l}\mathrm{As}^{*}, \mathrm{Ba}^{*}, \mathrm{Ca}^{* *}, \mathrm{Cd}^{*}, \mathrm{Hf}, \\
\mathrm{La}^{*}, \mathrm{Sb}, \mathrm{Sm}^{*}, \mathrm{Sr}^{*}, \mathrm{~W}^{*}, \\
\mathrm{Yb}\end{array}$ & $\mathrm{Zn}$ \\
\hline $\begin{array}{l}\text { Lupinus } \\
\text { arizonicus }\end{array}$ & $2 / 2$ & Luar & CK & $\mathrm{Mo}^{*}, \mathrm{Na}^{*}, \mathrm{Rb}^{*}, \mathrm{Sr}^{*}$ & $\begin{array}{l}\mathrm{As}, \mathrm{Ba}, \mathrm{Br}^{*}, \mathrm{Cr}^{*}, \mathrm{Hf}, \mathrm{Sb}, \\
\mathrm{Sc}^{*}, \mathrm{~W}^{*}, \mathrm{Zn}^{*}\end{array}$ \\
\hline $\begin{array}{l}\text { Lupinus } \\
\text { odoratus }\end{array}$ & $10 / 10$ & Luod & WM-N;GS & $\begin{array}{l}\mathrm{As} *, \mathrm{Ba}, \mathrm{Cd}, \mathrm{Co}, \mathrm{K}, \mathrm{La}, \\
\mathrm{Na}, \mathrm{Rb}^{*}, \mathrm{Sb}, \mathrm{Sr}, \mathrm{W}^{*}\end{array}$ & $\mathrm{Br}^{*}$ \\
\hline Lupinus species & $1 / 1$ & Lusp & WM-N & $\begin{array}{l}\mathrm{As}^{*}, \mathrm{Ba}^{*}, \mathrm{Cd}^{*}, \mathrm{Co}^{*}, \\
\mathrm{Cr}^{* *}, \mathrm{Cs}^{*}, \mathrm{Fe}^{*}, \mathrm{Hf}^{* *}, \\
\mathrm{~K}^{*}, \mathrm{La}^{*}, \mathrm{Lu}^{*}, \mathrm{Mo}^{*}, \\
\mathrm{Na}^{* *}, \mathrm{Rb}^{* *}, \mathrm{Sb}^{* *}, \mathrm{Sc}^{* *}, \\
\mathrm{Sm}^{* *}, \mathrm{Th}^{* *}, \mathrm{U}^{*}, \mathrm{~W}^{* *}, \\
\mathrm{Yb}^{* *}\end{array}$ & $\mathrm{Br}^{*}, \mathrm{Mo}^{*}$ \\
\hline $\begin{array}{l}\text { Malacothrix } \\
\text { glabrata }\end{array}$ & $8 / 8$ & Magl & GS & $\begin{array}{l}\mathrm{Ba}, \mathrm{Br}^{*}, \mathrm{Ca}^{*}, \mathrm{~K}, \mathrm{Na}^{*}, \mathrm{Sr}, \\
\mathrm{U}\end{array}$ & $\mathrm{As}, \mathrm{Co}, \mathrm{Cr}^{*}, \mathrm{Fe}, \mathrm{Sb}^{*}$ \\
\hline $\begin{array}{l}\text { Mentzelia } \\
\text { species }\end{array}$ & $1 / 1$ & Ment & WM-S & $\mathrm{Ca}, \mathrm{K}, \mathrm{Zn}$ & $\begin{array}{l}\mathrm{As}^{*}, \mathrm{Ba}, \mathrm{Br}^{*}, \mathrm{Co}^{*}, \mathrm{Cr}^{*}, \\
\mathrm{Cs}^{* *}, \mathrm{Fe}^{*}, \mathrm{Hf}^{*}, \mathrm{La}^{*}, \\
\mathrm{Lu}^{* *}, \mathrm{Mo}, \mathrm{Na}, \mathrm{Rb}^{*}, \\
\mathrm{Sb}^{* *}, \mathrm{Sc}^{*}, \mathrm{Sm}^{*}, \mathrm{Sr}, \mathrm{Th}^{* *}, \\
\mathrm{U}^{* *}, \mathrm{~W}^{* *}, \mathrm{Yb}^{* *}\end{array}$ \\
\hline $\begin{array}{l}\text { Mirabilis } \\
\text { californica }\end{array}$ & $2 / 2$ & Mica & WM-S & $\begin{array}{l}\mathrm{Ba}, \mathrm{Br}^{*}, \mathrm{Ce}^{*}, \mathrm{Cr}, \mathrm{Cs}, \mathrm{Fe}^{*} \text {, } \\
\mathrm{Hf}, \mathrm{K}^{*}, \mathrm{La}^{*}, \mathrm{Lu}, \mathrm{Na}, \\
\mathrm{Sb}^{*}, \mathrm{Sc}, \mathrm{Se}, \mathrm{Sm}^{*}, \mathrm{Th}, \\
\mathrm{Yb}^{*}\end{array}$ & As, $\mathrm{Lu}, \mathrm{Mo}^{*}$ \\
\hline $\begin{array}{l}\text { Mirabilis } \\
\text { bigelovii }\end{array}$ & $29 / 29$ & Mibi & WM-N/S;GS & $\mathrm{Br}^{*}, \mathrm{Ce}, \mathrm{K}, \mathrm{Na}, \mathrm{Rb}^{*}$ & None \\
\hline $\begin{array}{l}\text { Opuntia } \\
\text { basilaris }\end{array}$ & $15 / 24$ & Opba & WM-N;GS;GF & $\begin{array}{l}\mathrm{Ca}, \mathrm{Ce}, I n^{*}, M g^{*}, M n^{*}, \\
R e^{* *}\end{array}$ & $\begin{array}{l}\mathrm{As}, \mathrm{Mo}^{*}, \mathrm{Na}^{*}, \mathrm{Sb}, \mathrm{Zn} \\
\mathrm{Na}^{*}, \mathrm{Ti}, \mathrm{V}, \mathrm{Zn}, \mathrm{Ga}, \mathrm{Ge}, \\
A s, Z^{*}, M o^{*}, C s, T h, \\
P b^{*}, U^{*}\end{array}$ \\
\hline $\begin{array}{l}\text { Phacelia } \\
\text { tanacetifolia }\end{array}$ & $1 / 1$ & Phta & WM-S & $\mathrm{Ba}^{*}, \mathrm{Ca}^{*}, \mathrm{Sr}^{*}$ & $\begin{array}{l}\mathrm{As}^{* *}, \mathrm{Ce}^{*}, \mathrm{Co}, \mathrm{Cr}^{*}, \mathrm{Cs}^{*}, \\
\mathrm{Fe}^{*}, \mathrm{Hf}^{*}, \mathrm{La} \mathrm{Lu}^{* *}, \mathrm{Rb}^{*}, \\
\mathrm{Sb}^{*}, \mathrm{Sc}^{*}, \mathrm{Sm}^{*}, \mathrm{Th}^{* *}, \\
\mathrm{U}^{* *}, \mathrm{~W}^{* *}, \mathrm{Yb}^{*}\end{array}$ \\
\hline
\end{tabular}


Table 20 (continued)

\begin{tabular}{|c|c|c|c|c|c|}
\hline Species name & $\begin{array}{l}\text { No. sites/ } \\
\text { samples }\end{array}$ & Symbol & Areas & $\begin{array}{l}\text { Elements with } \\
\text { concentrations above } \\
\text { regional geometric mean } \\
\text { value }\end{array}$ & $\begin{array}{l}\text { Elements with } \\
\text { concentrations below } \\
\text { regional geometric mean } \\
\text { value }\end{array}$ \\
\hline Plantago ovata & $6 / 11$ & Plov & $\mathrm{GS} ; \mathrm{CK} ; \mathrm{CH} ; \mathrm{GF}$ & 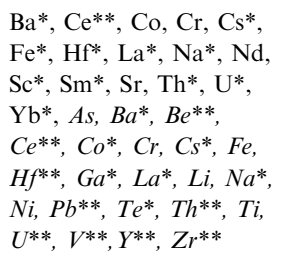 & $\begin{array}{l}\mathrm{Br}, \mathrm{K}^{*}, \mathrm{~W}^{* *}, C u^{*}, I n^{* *} \\
M g^{*}, M n^{*}, R e^{* *}, Z n\end{array}$ \\
\hline $\begin{array}{l}\text { Pleuraphis } \\
\text { rigida }\end{array}$ & $10 / 15$ & Plri & GF & $B r, I n^{*}, R e^{* *}$ & $\begin{array}{l}\mathrm{As}^{* *}, \mathrm{Ba}^{* *}, \mathrm{Ca}^{* *}, \mathrm{Cd}^{*}, \\
\mathrm{Fe}^{* *}, \mathrm{H}^{*}, \mathrm{~K}^{*}, \mathrm{La}^{*}, \mathrm{Lu}^{*}, \\
\mathrm{Mo}^{* *}, \mathrm{Na}^{*}, \mathrm{Rb}^{*}, \mathrm{Sb}^{* *}, \\
\mathrm{Sc}^{* *}, \mathrm{Sm}^{*}, \mathrm{Sr}^{*}, \mathrm{Yb}^{*}, \\
\mathrm{Zn}^{*}, \mathrm{Ba}^{*}, \mathrm{Be} e^{*}, \mathrm{Ca}, \mathrm{Cd}, \\
\mathrm{Ce}, \mathrm{Co}, \mathrm{Fe}, \mathrm{Ga}, \mathrm{K}, \mathrm{La}, \\
\mathrm{Li}, \mathrm{Mo}, \mathrm{Nb}, \mathrm{Pb}, \mathrm{Sr}, \mathrm{Te}, \\
T h^{*}, T i, U, V, \mathrm{Y}^{*}, \mathrm{Zr}^{*}\end{array}$ \\
\hline $\begin{array}{l}\text { Schismus } \\
\text { species }\end{array}$ & $30 / 30$ & Scsp & $\begin{array}{l}\text { WM-N/ } \\
\text { S;GF;GS;CK }\end{array}$ & $\begin{array}{l}A l, A s, C r, C s, C u^{* *} \\
I n^{* *}, K^{*}, M n, M o^{*}, N i \\
R e^{* *}, S c, S i, T e, T h, Z n\end{array}$ & $\begin{array}{l}\mathrm{Ba}, \mathrm{Br}, \mathrm{Ca}^{*}, \mathrm{Ce}, \mathrm{Cs}^{*}, \mathrm{~K}, \\
\mathrm{Na}, \mathrm{Rb}^{*}, \mathrm{Se}, \mathrm{Sr}, \mathrm{Th}, \mathrm{U}^{*}, \\
\mathrm{~W}^{*}, \mathrm{Yb}^{*}, B, L i, N a^{*}, S b, \\
T l, W, Z r^{*}\end{array}$ \\
\hline $\begin{array}{l}\text { Sphaeralcea } \\
\text { ambigua }\end{array}$ & $20 / 20$ & Spam & GS;WM-N;CK & $\mathrm{Br}, \mathrm{Ca}^{*}, \mathrm{Ce}, \mathrm{Hf}, \mathrm{U}^{*}, \mathrm{Zn}$ & None \\
\hline $\begin{array}{l}\text { Stephanomeria } \\
\text { exigua }\end{array}$ & $2 / 2$ & Stex & GS & $\mathrm{Br}, \mathrm{Cr}, \mathrm{K}, \mathrm{Na}^{*}, \mathrm{Rb}^{*}$ & $\mathrm{As}^{*}, \mathrm{Co}, \mathrm{La}, \mathrm{Lu}, \mathrm{Sb}$ \\
\hline $\begin{array}{l}\text { Stylocline } \\
\text { micropoides }\end{array}$ & $1 / 1$ & Stmi & WM-N & $\begin{array}{l}\mathrm{Ba}^{*}, \mathrm{Cd}^{* *}, \mathrm{Co}, \mathrm{Cr}^{* *}, \mathrm{Eu}, \\
\mathrm{Fe}^{* *}, \mathrm{Hf}^{* *}, \mathrm{La}^{* *}, \mathrm{Lu}^{*}, \\
\mathrm{Mo}^{* *}, \mathrm{Na}^{* *}, \mathrm{Nd}^{*}, \mathrm{Sb}^{*}, \\
\mathrm{Sc}^{*}, \mathrm{Th}^{* *}, \mathrm{U}^{* *}, \mathrm{~W}^{* *} \\
\mathrm{Yb}^{* *}, \mathrm{Zn}^{* *}\end{array}$ & $\mathrm{Br}, \mathrm{Cs} * *$ \\
\hline
\end{tabular}

Area abbreviations: WM-N/S $=$ Western Mojave, North or South Section; GS = Goldstone; $\mathrm{CK}=$ Chuckwalla Bench; $\mathrm{CH}=$ Chemehuevi Valley; GF = Goffs. Element symbol in italics determined in ashed material. All other elements determined in non-ashed material. For elements with concentrations above regional geometric mean value: ${ }^{*}=\gg 2$ times geometric mean value for element. ${ }^{*}=>2$ times geometric mean value for element. No symbol $=1.5-2.0$ times geometric mean value for element. For elements with concentrations below regional geometric mean value: ${ }^{* *}=\ll 0.5$ times geometric mean value for element; ${ }^{*}=<0.5$ times geometric mean value for element. No symbol $=0.50-0.67$ times geometric mean value for element.

In the Goldstone area, the range of reported concentrations for most elements, as well as the areas of mineralized rock and mining, are much more limited than in the Western Mojave area. As a result, anomalies are more subtle and thresholds for the included figures were selected instead at about two times the local mean value.

\subsection{Western Mojave Study Area-Southern Section}

\subsubsection{Soils}

Maximum concentrations in soil samples from the Western Mojave Study AreaSouthern Section that exceeded about two times their respective geometric mean values for each element in one or several samples were found for 17 elements (As, $\mathrm{Ca}, \mathrm{Ce}, \mathrm{Cr}, \mathrm{Eu}, \mathrm{Hg}$, $\mathrm{La}, \mathrm{Mo}, \mathrm{Nd}, \mathrm{Ni}, \mathrm{P}, \mathrm{Pb}, \mathrm{Sb}, \mathrm{Th}, \mathrm{Yb}$, and possibly $\mathrm{Au}$ and $\mathrm{U}$ ) (See bolded maximum 


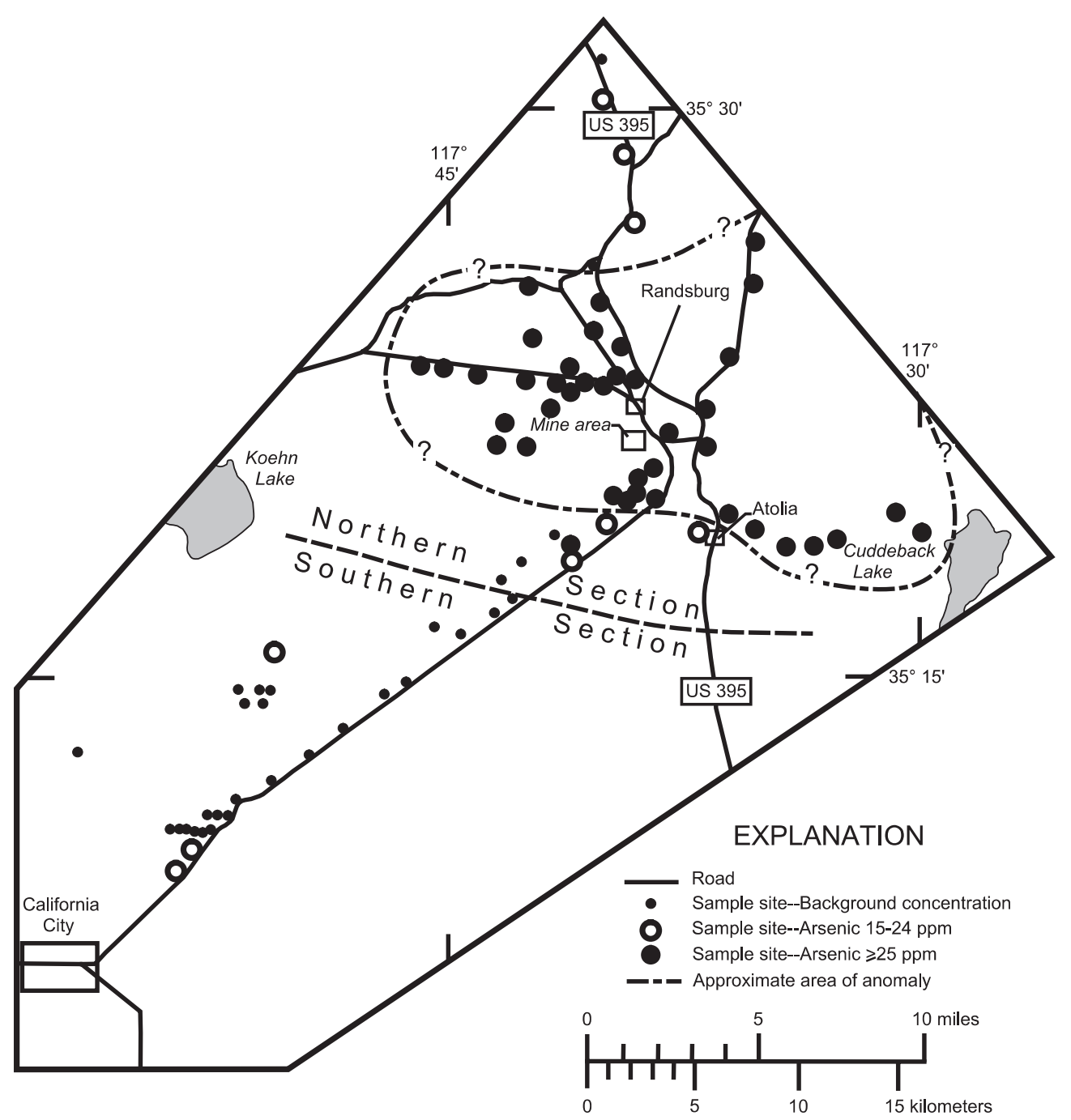

Fig. 4. Distribution of anomalous As in soils, Western Mojave Study Area, California, USA. Contour line encloses main area of samples with $\geqslant 25 \mathrm{ppm}$ As.

concentrations, Table 5) and were highest $(5.9 \times-112 \times$ the mean value) for $\mathrm{As}, \mathrm{Au}, \mathrm{Hg}$, and Ni. Samples with the highest concentrations for these four elements were found to be scattered throughout this study area. None of these anomalies could be related to any obvious sources other than geology or very localized contamination from unknown sources.

\subsubsection{Plants}

Maximum concentrations in one or more plant samples from the Southern Section exceeding about two times geometric mean values for each element from that area were found for all elements analysed for which sufficient analyses were available (Table 6). The 


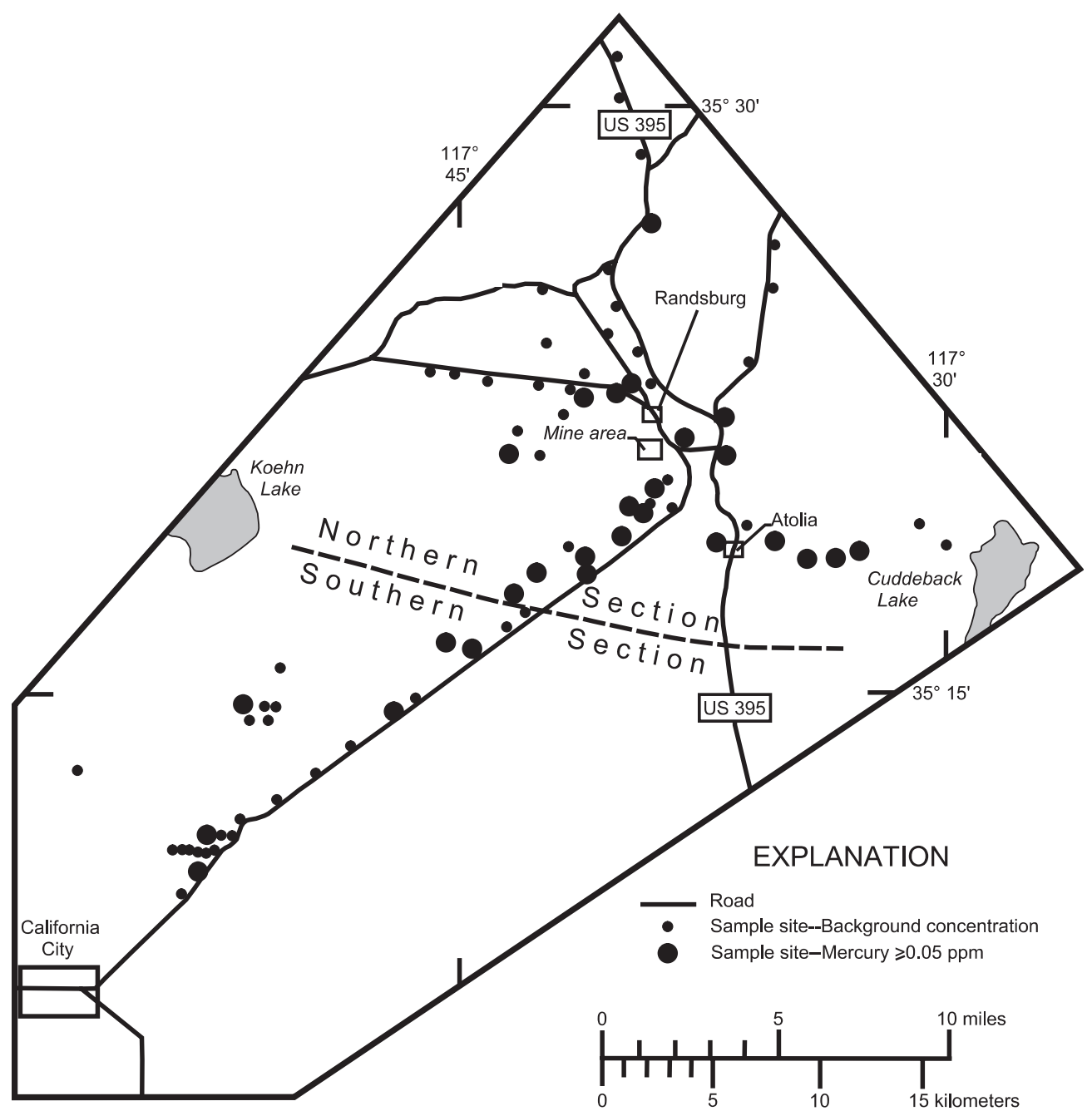

Fig. 5. Distribution of anomalous Hg in soils, Western Mojave Study Area, California, USA.

highest ratios of maximum concentration to geometric mean value $(10 \times-33 \times)$ were found for As, Au, Ce, Cr, Cs, Hf, La, Sb, Sc, Sm, Th, U, W, and Yb (See bolded maximum concentrations, Table 6). Samples with these high ratio values are from sites scattered throughout the area and are probably related to local lithology.

\subsection{Western Mojave Study Area-Northern Section}

\subsubsection{Soils}

Maximum concentrations in one or more soil samples exceeding $\sim 2 \times$ their geometric mean values for each element were found for 13 elements (As, $\mathrm{Au}, \mathrm{Ca}, \mathrm{Cr}, \mathrm{Hg}, \mathrm{Ni}, \mathrm{P}, \mathrm{Pb}$, $\mathrm{Sb}$, Ta, Th, U, W; see bolded maximum concentrations, Table 7). The highest ratios $(6.3 \times-128 \times)$ are for five mineral deposit-related elements (As, $\mathrm{Au}, \mathrm{Hg}, \mathrm{Sb}, \mathrm{W})$. Plots of 


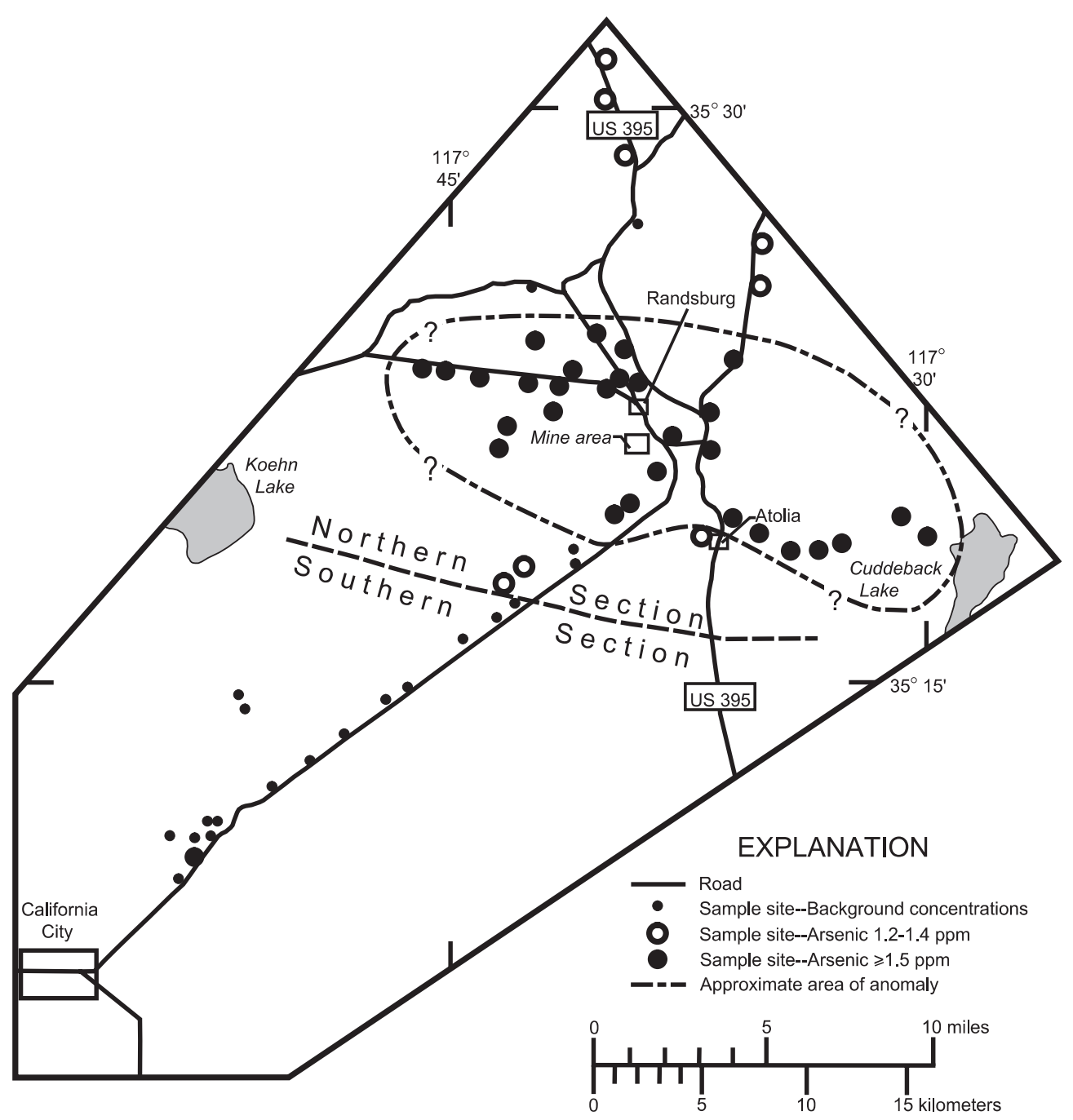

Fig. 6. Distribution of anomalous As in plants, Western Mojave Study Area, California, USA. Site is designated as anomalous if at least one sample is within concentration range shown. Contour line encloses main area of samples with $\geqslant 1.5 \mathrm{ppm}$ As.

$\mathrm{As}, \mathrm{Au}, \mathrm{Sb}$, and $\mathrm{W}$ indicate that high concentrations are mostly associated spatially with mineral deposits of the Rand and(or) Atolia districts. Distinct anomalies in soils extend outward as far as $\sim 15 \mathrm{~km}$ from the center of the area of mining. An example of this dispersion can be seen in Fig. 4, which shows the distribution of anomalous ( $\geqslant 15 \mathrm{ppm})$ As in soils. A 25-ppm contour, which is not entirely defined, extends well beyond the area containing mine dumps and tailing piles, indicating that fine material from mining waste has been transported for considerable distances beyond the area of mining, mainly by wind action and occasional flash floods. The highest concentration of As in soils was $510 \mathrm{ppm}$ (Table 7). 


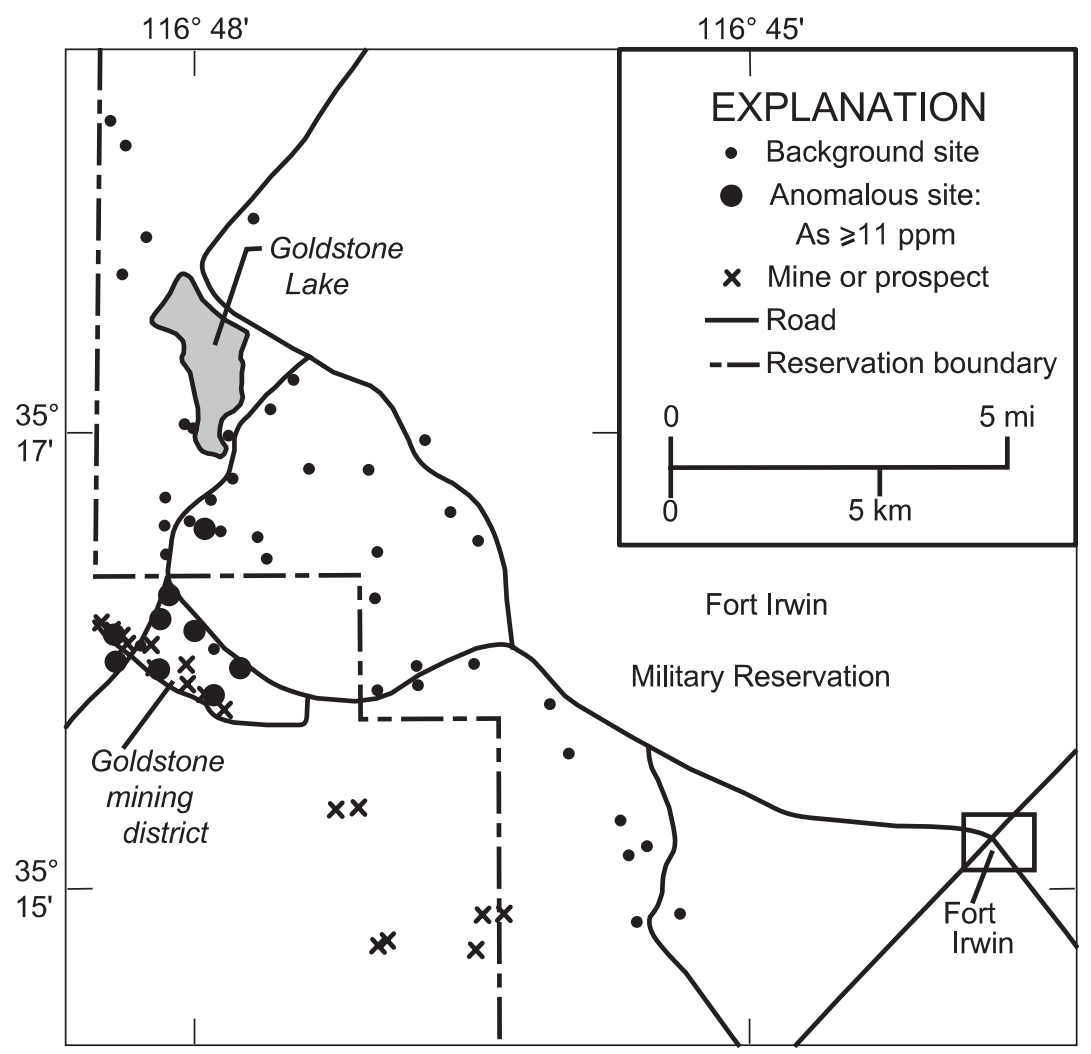

Fig. 7. Distribution of anomalous As in soils, Goldstone Study Area, Central Mojave Desert, California, USA.

Anomalous $(\geqslant 0.05 \mathrm{ppm}) \mathrm{Hg}$ is found in samples from scattered localities in and around the area of mining as well as in those from more distant sites (Fig. 5). Wind and water movement have dispersed fine tailings material as far as $\sim 6 \mathrm{~km}$ eastward from old tailings piles around the Atolia district. Many stream channels draining the periphery of the Rand and Atolia districts are still highly contaminated with transported mill tailings. Scattered anomalies are also found north, west, and south of the Rand district (Fig. 5). These anomalies probably result from a combination of wind action, occasional flash flooding, and contamination by vehicles hauling ore concentrates or other materials along the graded road from Randsburg to California City.

High concentrations for anomalous elements in this study area other than the five mentioned above are not spatially associated with the mineralized areas, are deemed to be natural, and are probably related to chemistry of rock units in the area or to concentrations of $\mathrm{Mn}$ or Fe oxides in B-horizon soils.

\subsubsection{Plants}

In the Northern Section, most elements were present in one or more plant samples in concentrations $>2 \times$ their local geometric mean values (Table 8). Elements with the highest maximum concentrations relative to their respective mean values $(9.0 \times-58 \times)$ 


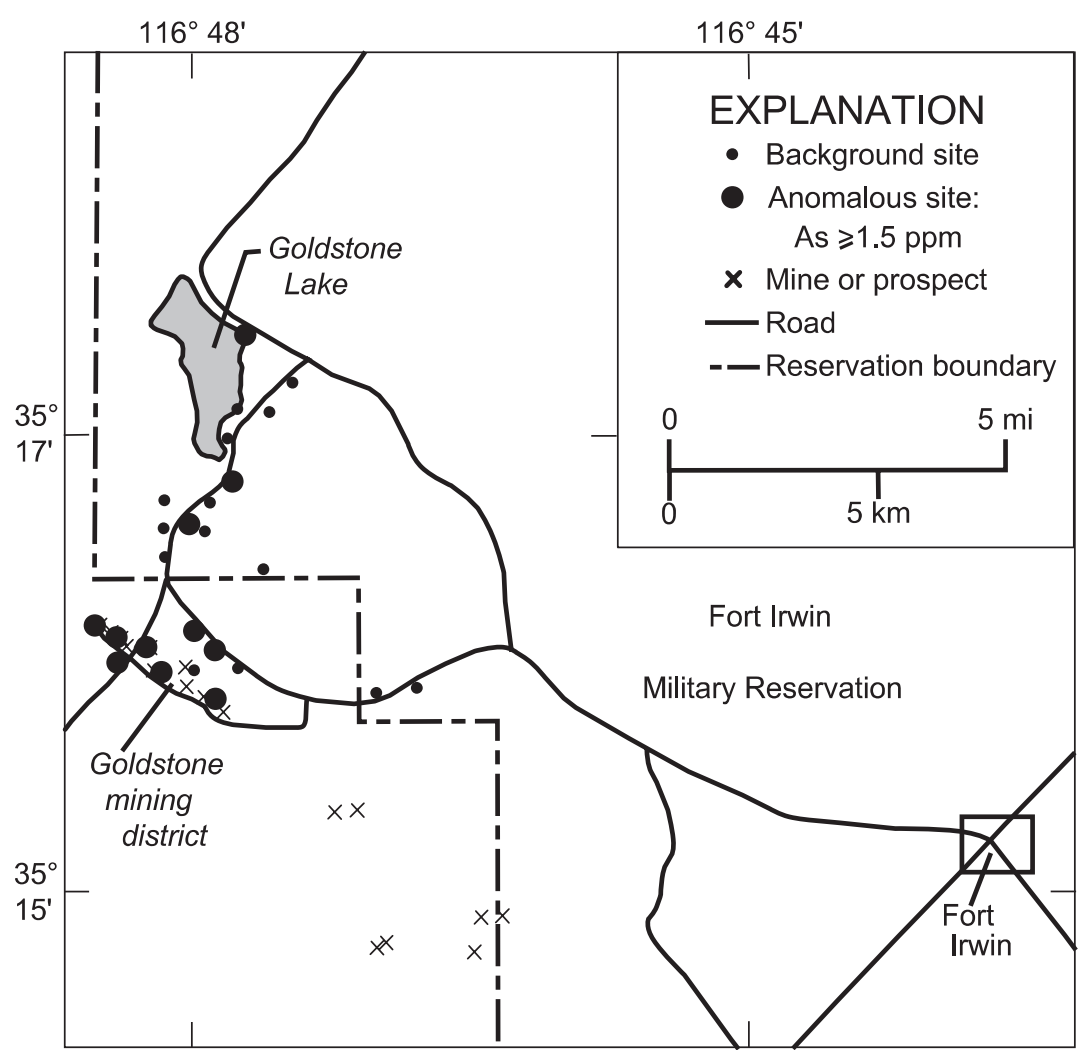

Fig. 8. Distribution of anomalous As in plants, Goldstone Study Area, Central Mojave Desert, California, USA.

include $\mathrm{As}, \mathrm{Au}, \mathrm{Ce}, \mathrm{Mo}, \mathrm{Na}$, and $\mathrm{Sb}$ (see bolded maximum concentrations, Table 8). Samples with the highest concentrations for $\mathrm{As}, \mathrm{Au}$, and $\mathrm{Sb}$ are found near the most strongly mineralized and (or) contaminated areas. Those for Mo and $\mathrm{Na}$ are mostly from samples collected in open valleys below Randsburg. High Ce concentrations are associated with areas of metamorphic rocks.

The distribution of anomalous $(\geqslant 1.2 \mathrm{ppm})$ As in all plants collected in the Western Mojave Study Area (Fig. 6) is in the Northern Section. The widespread extent of As $\geqslant 1.5 \mathrm{ppm}$, which is contoured in Fig. 6, is very similar to that for As in soils (Fig. 4). The distribution of $\mathrm{W}$ in plant samples (not shown) is closely spatially associated with the main area of $\mathrm{W}$ mining near Atolia. Both As and $\mathrm{W}$ are ore-related elements that are not essential for plant metabolism (Speidel and Agnew, 1982). Thus, we suspect that these two elements are present as contaminants on the surfaces of plant parts.

\subsection{Goldstone Study Area}

\subsubsection{Soils}

Maximum concentrations $>2 \times$ the local geometric mean values $(2.0 \times-124 \times)$ for each element in one or more soil samples were found for 14 elements (As, $\mathrm{Au}, \mathrm{Ca}, \mathrm{Cd}, \mathrm{Co}$, 
$\mathrm{Cr}, \mathrm{Cu}, \mathrm{Hg}, \mathrm{Mn}, \mathrm{Nb}, \mathrm{Ni}, \mathrm{Pb}, \mathrm{Th}, \mathrm{Y}$; see bolded maximum concentrations, Table 9). The high values for eight of these elements $(\mathrm{Ca}, \mathrm{Co}, \mathrm{Cr}, \mathrm{Mn}, \mathrm{Nb}, \mathrm{Ni}, \mathrm{Th}, \mathrm{Y})$ are natural and are related to the chemistry of local rock units such as carbonate-rich or granitic rocks, or to concentrations of $\mathrm{Mn}$ or Fe oxides in B-horizon soils.

Samples of rock from mine dumps in the Goldstone mining district contained anomalous concentrations of at least eight elements ( $\mathrm{Ag}, \mathrm{As}, \mathrm{Cd}, \mathrm{Cu}, \mathrm{Mo}, \mathrm{Pb}, \mathrm{Sb}, \mathrm{Zn}$; Chaffee, M.A., 2006, unpub. data). Plots of high concentrations of five elements (As, Au, $\mathrm{Cd}, \mathrm{Cu}, \mathrm{Mo}$ ) in soils show anomalies that are deemed to be associated with mineral deposits of the Goldstone district. Distinct anomalous dispersion patterns extend northward at least several kilometers from the area of mining. The best example of this dispersion can be seen in Fig. 7, showing the distribution of anomalous ( $\geqslant 11 \mathrm{ppm}$ ) As in soils. Most of this dispersion is deemed to be the result of wind action or occasional flash floods. Soil samples contained as much as $72 \mathrm{ppm}$ As (Table 9).

\subsubsection{Plants}

Most elements were present in plants from the Goldstone area in concentrations exceeding $\sim 2 \times$ their local geometric mean values (Table 10), with the highest enrichment values $(7.9 \times-24 \times)$ for $\mathrm{As}, \mathrm{Au}, \mathrm{Mo}, \mathrm{Rb}$, and $\mathrm{W}$ (see bolded maximum concentrations, Table 10), which are mostly elements associated with the local mineral deposits. Samples with high concentrations are mostly found in and north of the Goldstone mining district. The highest concentrations for $\mathrm{Ca}$ and $\mathrm{Sr}$ are in samples collected in or near areas containing carbonate-rich sedimentary rocks. Samples with high concentrations for most other elements are from locations scattered throughout the study area and are deemed to be related to natural chemistry of local geologic units, which suggests that some of the plant material analysed may include local surface contamination of eolian dust or substrate materials.

A plot of anomalous $(\geqslant 1.5 \mathrm{ppm})$ As in all plant samples collected in the Goldstone area (Fig. 8) shows dispersion of this element northward from the mining district. Anomalous samples are found both in and north of the area of past mining, including scattered samples from sites as far as $8 \mathrm{~km}$ north of the district.

\subsection{Goffs Study Area}

\subsubsection{Soils}

Only As was found in a sample with a maximum concentration $>2 \times$ the local geometric mean value (see bolded maximum concentration, Table 11). This one value $(7 \mathrm{ppm})$ is not deemed to be truly anomalous in a regional context and is considered to represent only a relatively high, natural concentration level.

Soils collected along traverses perpendicular and adjacent to old US Highway 66 and the railroad right-of-way showed no obvious anomalies of elements such as $\mathrm{Pb}$ that could be related to effects of contamination from either highway or railroad traffic.

\subsubsection{Plants}

Maximum concentrations in both non-ashed and ashed plant samples exceeding $\sim 2 \times$ geometric mean values for each element in one or several samples were found for most elements analysed (Tables 12 and 13), with the highest values $(14 \times-70 \times)$ in non-ashed plans for $\mathrm{Au}$ and Mo (see bolded maximum concentrations, Table 12) and the highest 
values for ashed plants $(10 \times-76 \times)$ for Mo, Re, Th, and $\mathrm{U}$ (see bolded maximum concentrations, Table 13). High maximum concentrations were found in all species collected in this area. Plots of respective element concentrations indicate that the highest concentrations for many are in samples collected near old US Highway 66 and the railroad right-of-way. Equivalent high concentrations were not found in soils collected near the highway or railroad, suggesting that these high concentrations in plants were largely the result of air-borne contaminants, and that at least some of these contaminants may have been introduced and dispersed as a result of highway and railroad traffic.

\subsection{Chemehuevi Valley Study Area}

\subsubsection{Soils and sediments}

Maximum concentrations exceeding $\sim 2 \times$ local geometric mean values $(2.1 \times-4.1 \times)$ for each element in one or more soil samples were found for five elements $(\mathrm{As}, \mathrm{Cr}, \mathrm{Mo}, \mathrm{Pb}$, Th; see bolded maximum concentrations, Table 14). Plots of these elements (not shown here) reveal that samples with anomalous elements, with the possible exception of $\mathrm{Pb}$, are scattered throughout the study area. These observations suggest that As, Cr, Mo, and Th are probably anomalous as a result of natural enrichments in $\mathrm{Fe}$ or $\mathrm{Mn}$ oxides formed in B-horizon soils or in residual minerals, such as apatite and monazite, that may be present in the soils.

Analyses of soils collected along several traverses perpendicular and adjacent to US Highway 95 showed a slight but consistent elevation in $\mathrm{Pb}$ concentrations along either side of the highway (Fig. 9). These concentrations $(20-51 \mathrm{ppm} \mathrm{Pb})$ extend as far as $\sim 22 \mathrm{~m}$ from the pavement edge, but are mostly confined to a zone $\sim 3-5 \mathrm{~m}$ wide on each side of the highway. Other metallic elements $(\mathrm{Cr}, \mathrm{Cu}, \mathrm{Mo}, \mathrm{V}, \mathrm{Zn})$ were also slightly anomalous in one or several samples collected near the highway. However, none was consistently anomalous as was $\mathrm{Pb}$, suggesting that the main source of $\mathrm{Pb}$ was probably motor vehicle exhaust from leaded fuel.

Maximum concentrations exceeding $\sim 2 \times$ local geometric mean values $(2.1 \times-3.3 \times)$ for each element in one or more sediment samples were found for 18 elements $(\mathrm{Au}, \mathrm{Ca}, \mathrm{Ce}$, $\mathrm{Co}, \mathrm{Cr}, \mathrm{Cu}, \mathrm{Fe}, \mathrm{Hf}, \mathrm{La}, \mathrm{Mn}, \mathrm{Nd}, \mathrm{Ta}, \mathrm{Tb}, \mathrm{Th}, \mathrm{Ti}, \mathrm{U}, \mathrm{V}, \mathrm{Zn}$; see bolded maximum concentrations, Table 15). Plots of all of these elements suggest that higher concentrations in sediment are natural and are in samples found: (1) in wash sediments that are enriched in minerals that are relatively resistant to weathering, such as magnetite, apatite, and monazite; and (2) as enrichments in Mn-oxide coatings present on sediment grains.

\subsubsection{Plants}

Maximum concentrations exceeding about two times local geometric mean values for each element in one or several plant samples were found for many elements (Table 16). Elements with the highest enrichments $(2.6 \times-10 \times)$ include $\mathrm{Ag}, \mathrm{B}, \mathrm{Ba}, \mathrm{Re}, \mathrm{Se}, \mathrm{Zn}$ (see bolded maximum concentrations, Table 16). Plots of these elements indicate that the highest concentrations for many are in samples collected near US Highway 95. This distribution suggests that most of these elements are enriched as a result of contamination by dust dispersed near the highway. 


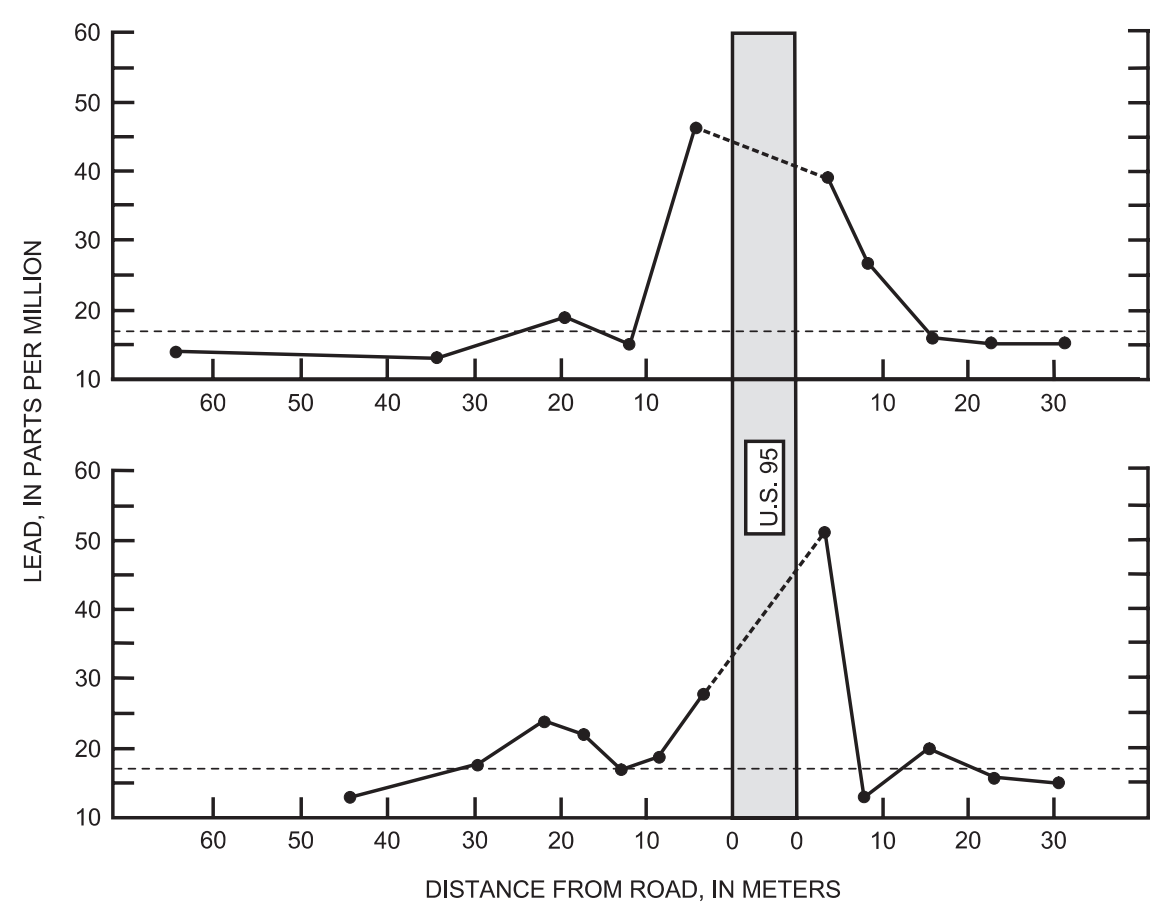

Fig. 9. Traverse profiles showing Pb content in soils near Highway 95, Chemehuevi Valley Study Area, Colorado Desert, California, USA. Horizontal dashed line indicates local threshold level.

\subsection{Chuckwalla Bench Study Area}

\subsubsection{Soils and sediments}

Maximum concentrations exceeding about two times local geometric mean values for each element in one or more soil samples are probably not meaningful (Table 17) because only five samples were evaluated.

Maximum concentrations exceeding $2 \times$ local geometric mean values $(2.1 \times-4.4 \times)$ for each element in sediment samples were found for 7 elements (As, Mo, Ni, Ta, Tb, Th, U; see bolded maximum concentrations, Table 18). Plots of these elements indicate that the higher concentrations are scattered throughout the area. These high concentrations are likely natural and in samples found: (1) in wash sediments enriched in minerals that are relatively resistant to weathering, such as magnetite, apatite, and monazite; and (2) as enrichments in Fe- and $\mathrm{Mn}$-oxide coatings present on sediment grains.

\subsubsection{Plants}

Concentrations exceeding $\sim 2 \times$ local geometric mean values for each element in one or several Chuckwalla Bench plant samples were found for most elements analysed, with the highest values $(4.0 \times-23 \times)$ found for 13 elements $(\mathrm{Au}, \mathrm{Ca}, \mathrm{Ce}, \mathrm{Cs}, \mathrm{Hf}, \mathrm{La}, \mathrm{Lu}, \mathrm{Sb}, \mathrm{Sc}$, $\mathrm{Sm}, \mathrm{U}, \mathrm{W}, \mathrm{Zn}$; see bolded maximum concentrations, Table 19). These high concentrations were found in all species collected in this area. Plots of these high concentrations indicate that the highest values are found scattered throughout the study area. Contamination of the surfaces of plants with eolian dust or substrate materials would seem to be the primary 
source of relatively high concentrations of most non-essential elements determined in these plant samples.

\section{Discussion and conclusions}

To determine if naturally occurring elements likely to act as toxicants or contaminants to tortoises are readily available in the surface environment, we sampled, chemically analysed, and compared data sets of analyses of soils, active stream sediments, and plants from six areas containing tortoise habitat. Because soil data from a given site can be used to provide context to the chemistry of plants growing nearby, we compared soil and plant chemistries to determine whether plants contained unusual concentrations of selected elements, including any that might be toxic to tortoises.

The regional stream-sediment, soil, and plant analyses show distinct variations in their bulk chemistry from locality to locality. These variations are consistent with the many types of rock units exposed in the region and their highly variable bulk mineralogies and chemical contents. As viewed on a regional basis and when compared to typical concentrations expected for most elements determined (as measured by published data, for example, on crustal abundances for these elements), no highly unusual concentrations were found for any of the elements determined except As and perhaps Sb. However, significant local anomalies are present in most of the study areas for many different elements.

Our data tables and figures provide new information on abundances and distributions of various elements in stream sediments, soils, and plants. By comparing geometric mean values and ranges of concentrations both between and within areas, differences in local chemistries can be identified. These data help to distinguish the ranges of background and anomalous concentrations for each element, sample medium, and location.

Our analyses also provide a baseline reference data set for the sampling period between 1997 and 2001. Any of these areas could be re-sampled in the future to determine whether any chemical changes have occurred with time. Re-sampling of road traverses or areas of mining, for instance, would reveal whether concentrations of anthropogenic contaminants are increasing or decreasing, or whether the extents of previously defined anomalies have increased or decreased.

Most soil, sediment, and plant samples exhibiting enrichment values greater than about 1.2 times the respective local or regional geometric mean values for a given element simply represent extreme concentrations of elements that are naturally enriched as a result of the varying chemistry of different rock units. However, some anomalous concentrations are clearly anthropogenic in origin and result from mining activities or from vehicle movement along roads crossing individual study areas.

We did not sample in areas of the National Training Center-Fort Irwin that are currently used for military exercises. However, the small part of Fort Irwin that we did sample did not produce any soil or plant anomalies for elements such as $\mathrm{As}, \mathrm{Br}, \mathrm{Ca}, \mathrm{Cu}$, $\mathrm{Cr}, \mathrm{Fe}, \mathrm{Mn}, \mathrm{Na}, \mathrm{Ni}, \mathrm{Pb}$, and $\mathrm{Zn}$ that could be related either to abandoned military ordnance, military vehicles, or other military activities (Forman et al., 2003).

Sediment samples in the Chuckwalla Bench Study Area, which were all collected downstream from the northern boundary of the Chocolate Mountains Aerial Gunnery Range, also did not reveal any significant anomalies for these same elements that could be related to military ordnance or vehicles. Additionally, no sediment or soil anomalies for 
elements that might be related to World War II military activities were found in the Goffs, Chemehuevi Valley, and Chuckwalla Bench study areas.

In the Goldstone Study Area, past mining in the Goldstone district has produced anomalies in soil and(or) plant samples of $\mathrm{As}, \mathrm{Au}, \mathrm{Cd}, \mathrm{Cu}$, and $\mathrm{Mo}$ that extend several kilometers north of the area of mining activity. These mining-related elements were dispersed northward, primarily by wind action, with some additional dispersion by possible flash flooding.

Soil samples collected in the vicinity of the Rand and Atolia districts in the Western Mojave Study Area-Northern Section contained anomalously high concentrations of one or more of the ore-related elements $\mathrm{As}, \mathrm{Au}, \mathrm{Sb}$, and $\mathrm{W}$. Plots of these anomalous concentrations show that they extend as far as $\sim 15 \mathrm{~km}$ outward from the past and recent areas of mining and are probably a result of wind-transported dust, as well as occasional flash floods, that carried material away from these areas. Although these extensive soil anomalies surrounding much of the Rand and Atolia districts are probably related to mining activity, we cannot say with certainty whether these anomalies were created during the early days of mining (about 1890-1950) or in more recent times. Plots of other, nonmineral deposit-related, elements determined in soils suggest that most, or possibly all, of the high concentrations for these elements are natural and related to chemistry of rock units in the area or to concentrations of $\mathrm{Ca}$ (calcrete) or of $\mathrm{Mn}$ or Fe oxides that are found in B-horizon soils.

In addition to ore-related elements found in the mineral deposits of the Rand and Atolia districts, the mill tailings remaining there also contain anomalies of $\mathrm{Hg}$, which was used to treat $\mathrm{Au}$ ores. Wind action, as well as flash flooding, have dispersed this fine tailings material as far as $\sim 6 \mathrm{~km}$ eastward from old tailings piles at Atolia and at least $10 \mathrm{~km}$ southwestward from the Rand district. Many stream channels draining the periphery of these districts are still highly contaminated with transported mill tailings that contain mineral deposit-related elements, as well as $\mathrm{Hg}$.

We also looked at the effects of vehicle exhaust and vehicle movement-caused transportation of dust by sampling soils in traverses intersecting US Highway 95 in the Chemehuevi Valley Study Area and the Goffs Road/US Highway 66, near the Goffs Study Area. We detected a subtle, weak, near-surface anomaly for $\mathrm{Pb}$ at the Chemehuevi Valley area that extended as far as $\sim 22 \mathrm{~m}$ away from the pavement edge. No other elements were consistently enriched in these traverse soils. Thus this $\mathrm{Pb}$ anomaly is probably related to vehicle exhausts containing leaded fuels. In the Goffs area, no $\mathrm{Pb}$ or other anomalies that could be related to vehicles or trains were found near the highway or railroad right-of-way. However, at both the Chemehuevi Valley and Goffs study areas, anthropogenic features such as elevated berms (Chemehuevi Valley), multiple alterations of the road pathway (Chemehuevi Valley, Goffs), bulldozing of the verge and drainage channels (Chemehuevi Valley, Goffs), and construction of an additional railroad track (Goffs) have combined with natural drainage systems to frequently alter surfaces originally generated by wind and water. Thus, any anomalies for elements typically associated with vehicles or roads (Br, $\mathrm{Ca}, \mathrm{Cd}, \mathrm{Co}, \mathrm{Cu}, \mathrm{Fe}, \mathrm{Mn}, \mathrm{Na}, \mathrm{Ni}, \mathrm{Pb}$, and [or] $\mathrm{Zn}$ ) may have been diluted by recent disturbance of surface materials (Forman et al., 2003). In road systems experiencing less disturbance, the results could be different (Forman et al., 2003; Sutherland et al., 2000). For heavy metals, distinct gradients with elevated concentrations typically extend from 50 to $100 \mathrm{~m}$ on either side of highways (Forman et al., 2003). 
In the areas around the Rand, Atolia, and Goldstone mining districts, some individual plants exhibited anomalous concentrations of elements such as As, Sb, W, Zn, and possibly $\mathrm{Au}$, all elements associated with mineral deposits. Most of these anomalies are probably from contaminants transported by wind action.

Relatively high concentrations of elements that are non-essential for plant metabolism, such as As, Ba, Ce, Cr, Cs, Cu, Hf, La, Lu, Ni, Sb, Sc, Sm, Th, U, W, Yb, and possibly Au, were determined in some plant samples. Because of the small sample size used, anomalous concentrations for $\mathrm{Au}$ in plant material are probably not very meaningful. We suspect that high concentrations of the rest of these elements are mostly in fine, particulate material that is present as a surface contaminant on above-ground parts of plants. Although these elements are not essential ones, a small amount of any of them could also have been translocated into the plant itself. We conclude that most of the high concentrations for this group of elements are a result of wind-borne dust: (1) transported from areas of past or present mining; (2) mobilized by vehicle traffic on nearby roads; or (3) eroded from local outcrops of various rock units.

A review of our individual plant analyses also identified a number of species (Appendix 1) that commonly contain higher concentrations of four selected essential elements $(\mathrm{Ca}, \mathrm{K}, \mathrm{Mo}$, and $\mathrm{Zn})$ than do other species. Those species with relatively high contents of $\mathrm{Ca}$ include Amte, Cabo, Erci, Lohu, Loto, Magl, Mibi, and Opba. Those with high contents of K include Amte, Asac, Asla, Asle, Cabo, Erci, Losa, Loto, Luar, Luod, Magl, Mibi, Opba, Spam, and Stex, with the species Erci, Luod, Magl, Mibi, Spam, and Stex having particularly high concentrations. Molybdenum has generally high contents in Achy, Asla, Asle, Brsp, Cabo, Cacl, Chem, Chcm, Chwm, Erci, Losa, Loto, Luar, Luod, Magl, Mibi, Scsp, Spam, Stex, and Stmi, with Erci, Mibi, and Scsp being particularly enriched. The species Chem, Chcm, Chwm, Spam, and Stex are generally high in Zn. We do not know if any of the high element concentrations for the species listed above or in Table 20 are typical of respective species in all six study areas. Thus, we cannot state with certainty that any of these species are routinely accumulating unusual quantities of these elements.

Arsenic is probably the most potentially toxic element to tortoises of all those determined for this study. High As concentrations were found almost exclusively in plant samples collected in or near areas known to be contaminated by mining of As-rich ores (Western Mojave-Northern Section and, to a lesser extent, Goldstone). The highest As concentrations ( $>5$ ppm dry weight) were found in 13 different species (Asac, Asdi, Asla, Cabo, Chbr, Chwm, Erci, Lohu, Luod, Mibi, Opba, Scsp, and Spam). However, high concentrations are not consistent for samples of any one species. Of these 13, five (Asac, Asdi, Asla, Lohu, and Luod) are from the legume family and are favored foods for tortoises (Appendix 1) (Jennings, 1993, 2002). However, the other eight species (Cabo, Chbr, Chwm, Erci, Mibi, Opba, Scsp, and Spam) are also consumed by tortoises.

Our chemical data demonstrate that bulk surface chemistry throughout the region varies from locality to locality. Potentially toxic elements in soil, sediment, and(or) plants may be available to tortoises in some areas; however, we emphasize that most of the analyses determined for this study are based on chemical techniques that provide a total analysis, which may or may not provide concentrations equivalent to those that are bio-available to animals. Bio-available concentrations are generally lower than those we obtained. Availability of potentially toxic elements to tortoises is likely to be dependent in part on the type and extent of historic and current anthropogenic activities (e.g. mining, vehicles) 
that either disturb the surface or add to existing soil, sediment, and plant chemistries through dust or airborne particulate matter. Although potentially toxic elements have been found in higher concentrations in sick tortoises than in control animals (Berry et al., 2001; Jacobson et al., 1991), direct cause and effect relationships to health remain to be demonstrated.

The sites with elevated levels $(\geqslant 0.05 \mathrm{ppm})$ of $\mathrm{Hg}$ in the Western Mojave Study Area provide an indication of the potential source of the $\mathrm{Hg}$ found in livers of ill desert tortoises at the Desert Tortoise Research Natural Area north of California City (Jacobson et al., 1991). Likewise, the elevated levels of As in soils and plants in the Western Mojave Study Area and at other sites support the findings of elevated As levels in tissues of ill tortoises from these same areas (Berry et al., 2001; Seltzer and Berry, 2005).

\section{Research issues to be addressed}

This investigation was conducted to determine the abundance and distribution of selected elements in soils, sediments, and(or) plants collected in six tortoise habitats and the region that encompasses them. Several elements, notably As, were found to be clearly anomalous in several of these habitats. For this study, we determined only chemical elements and not any chemical compounds, such as mineral phases or organic chemicals. Also, the analyses typically determined the total concentration of a given element, without regard to how much of that element would be bio-available. Additionally, many elements have more than one oxidation state. Commonly, only one oxidation state for a given element is known to be toxic. For example, $\mathrm{As}^{3+}$ may be toxic, whereas $\mathrm{As}^{5+}$ generally is not. Methyl $\mathrm{Hg}$ is toxic, but elemental $\mathrm{Hg}$ generally is not. Because we only measured total concentrations of individual elements, we do not know the effects of: (1) different oxidation states; (2) inorganic chemical compounds, including mineral phases; or (3) organic chemicals, such as those naturally present in plants or in contaminants on the surface of plants.

For future research, we suggest that the distribution and abundance of elements in the tortoise forage plants be evaluated for the respective roles of dust and systemic uptake. We did not wash the plants to remove dust; paired samples of washed and unwashed plants could be compared. For the desert tortoises, we suggest that the next steps involve: (1) additional necropsies on any available tortoises from these six study areas or elsewhere to build a data base of chemical concentrations in selected organs of tortoises; and (2) experimental research to test hypotheses about how specific toxicants or groups of toxicants affect general tortoise health, immune systems, susceptibility to diseases, and mortality. While correlative studies are helpful, they will not shed light on how toxicants enter the body and affect health.

\section{Acknowledgements}

We were assisted in the field by B. Hauser, F. Hauser, and W. Quillman. H. King, US Geological Survey, helped with sample preparation. We especially thank W. Quillman for advice and both logistical and financial support. Reviews of earlier versions of this manuscript by C. Hui, K. Phillips, M. Seltzer, H. Lowers and S. Smith are gratefully acknowledged. This project was supported by the US Geological Survey and the Department of the Army, National Training Center, Fort Irwin. 


\section{Appendix 1}

List of plant taxa and plant types that were chemically analysed. All are from Mojave and Colorado Deserts, southeastern California, USA (Table A1).

Table A1

Type of plant and species

Symbol

Forbs: Herbaceous annual/perennial species

Astragalus acutirostris ${ }^{\mathrm{a}}$

Astragalus didymocarpus ${ }^{\mathrm{a}}$

Astragalus layneae $\mathrm{a}^{\mathrm{a} b}$

Astragalus lentiginosus ${ }^{\mathrm{a}}$

Astragalus species ${ }^{\mathrm{a}}$

Camissonia boothii $^{\mathrm{a}}$

Asac

Camissonia claviformis

Chamaesyce species $^{\mathrm{a}, \mathrm{b}}$

Chorizanthe brevicornu ${ }^{\mathrm{a}}$

Chorizanthe species

Ditaxis species

Asdi

Lotus humistratus ${ }^{\mathrm{a}}$

Asla

Lotus salsuginosus var. brevivexillus ${ }^{\mathrm{a}}$

Asle

Lotus tomentellus ${ }^{\mathrm{a}}$

Assp

Cabo

Lupinus arizonicus ${ }^{\mathrm{a}}$

$\mathrm{Cacl}$

Lupinus odoratus $^{\mathrm{a}}$

Chwm, Chem, Chcm, Chec

Chbr

Lupinus species $^{\mathrm{a}}$

Chsp

Dita

Lohu

Losa

Loto

Luar

Luod

Malacothrix glabrata

Lusp

Mentzelia species ${ }^{\mathrm{b}}$

Magl

Mirabilis bigelovii

Ment

Mirabilis californica ${ }^{\mathrm{b}}$

Mibi

Phacelia tanacetifolia $^{\mathrm{a}, \mathrm{b}}$

Mica

Plantago ovata ${ }^{\mathrm{a}, \mathrm{b}}$

Phta

Stylocline micropoides ${ }^{\mathrm{a}, \mathrm{b}}$

Plov

Perennial Grass Species

Achnatherum hymenoides ${ }^{\mathrm{a}}$

Achy

Achnatherum speciosum

Acsp

Pleuraphis rigida ${ }^{\mathrm{a}}$

Plri

Sphaeralcea ambigua ${ }^{\mathrm{a}, \mathrm{b}}$

Spam

Stephanomeria exigua ${ }^{a}$

Stex

Alien Annual Species

Bromus species $^{\mathrm{a}}$

Brsp

Erodium cicutarium ${ }^{a}$

Erci

Schismus species $^{\mathrm{a}}$

Scsp

Cacti

Opuntia basilaris $^{\mathrm{a}}$

Opba

Weed Species

Amsinckia tessellata $^{\mathrm{b}}$

Amte

Perennial Shrub

Fouquieria splendens

Fosp

${ }^{\mathrm{a}}$ Favored tortoise food or known to be consumed by tortoises.

${ }^{\mathrm{b}}$ Pubescent and (or) glandular plant commonly with inorganic surface contamination. 


\section{References}

ActLabs-Skyline, 2001. 2001 Fee Schedule. Actlabs-Skyline, Tucson, AZ, pp. 24.

Berry, K.H., 1986. Desert tortoise (Gopherus agassizii) relocation: implications of social behavior and movements. Herpetologica 42, 113-125.

Berry, K.H., 1997. The Desert Tortoise Recovery Plan: an ambitious effort to conserve biodiversity in the Mojave and Colorado deserts of the United States. In: Van Abbema, J. (Ed.), Proceedings: Conservation, Restoration, and Management of Tortoises and Turtles-An International Conference. "Wildlife Conservation Society Turtle Recovery Program and New York Turtle and Tortoise Society, New York, NY, pp. 430-440.

Berry, K.H., Homer, B.L., Alley, W., Chaffee, M., Haxel, G., 2001. Health and elevated mortality rates in desert tortoise populations: the role of arsenic and other potential toxicants. Abstract, Arsenic Group Meeting, US Geological Survey, Denver, CO. February 21-22, 2001.

Berry, K.H., Spangenberg, E.K., Homer, B.L., Jacobson, E.R., 2002. Deaths of desert tortoises following periods of drought and research manipulation. Chelonian Conservation and Biology 4, 436-448.

Briggs, P.H., 1996. Forty elements by inductively coupled plasma-atomic emission spectrometry. In: Arbogast, B.F. (Ed.), Analytical Methods Manual for the Mineral Resource Surveys Program. US Geological Survey Open-File Report 96-525, pp. 77-94.

Brown, M.B., Schmacher, I.M., Klein, P.A., Harris, K., Correll, T., Jacobson, E.R., 1994. Mycoplasma agassizii causes upper respiratory tract disease in the desert tortoise. Infection and Immunity. 62, 4580-4586.

Brown, M.B., Berry, K.H., Schumacher, I.M., Nagy, K.A., Christopher, M.M., Klein, P.A., 1999. Seroepidemiology of upper respiratory tract disease in the desert tortoise in the western Mojave Desert of California. Journal of Wildlife Diseases 35, 716-727.

Burge, B.L., Bradley, W.G., 1976. Population density, structure and feeding habits of the desert tortoise, Gopherus agassizii, in a low desert study area in southern Nevada. In: Proceedings of the Desert Tortoise Council Symposium, 1976, 51-74.

Clark, W.B., 1970. Gold districts of California. California Division of Mines and Geology Bulletin 193. Sacramento, CA.

Cloudman, H.C., Huguenin, E., Merrill, J.H., Tucker, W.B., 1919. Goldstone District. In: Mines and mineral resources of portions of California: Report XV, part VI of the State Mineralogist, pp. 804-807. California Divsion of Mines and Geology. Sacramento, CA.

Fish and Wildlife Service, 1990. Endangered and threatened wildlife and plants; determination of threatened status for the Mojave population of the desert tortoise. Federal Register 55, $12178-12191$.

Fish and Wildlife Service, 1994. Desert Tortoise (Mojave population) Recovery Plan. US Fish and Wildlife Service, Portland, OR, pp. 73, plus appendices.

Forman, R.T.T., Sperling, D., Bissonette, J.A., Clevenger, A.P., Cutshall, C.D., Dale, V.H., Fahrig, L., France, R., Goldman, C.R., Heanue, K., Jones, J.A., Swanson, F.J., Turrentine, T., Winter, T.C., 2003. Chemicals along roads. In: Forman, R.T.T., et al. (Eds.), Road Ecology, Science and Solutions. Island Press, Washington, DC pp. 201-223.

Henen, B.T., Peterson, C.C., Wallis, I.R., Berry, K.H., Nagy, K.A., 1998. Effects of climatic variation on field metabolism and water relations of desert tortoises. Oecologia 117, 365-373.

Hess, F.L., 1910. Gold mining in the Randsburg quadrangle, California. In: Hayes, C.W., Lindgren, W. (Eds.), Contributions to Economic Geology 1909, Part I, Metals and Non-metals Except Fuels, vol. 430. US Geological Survey Bulletin, pp. 23-47.

Hickman, J.C. (Ed.), 1993. The Jepson Manual, Higher Plants of California. University of California Press, Berkeley, CA.

Homer, B.L., Berry, K.H., Christopher, M.M., Brown, M.B., Jacobson, E.R., 1998. Pathology of diseases in wild desert tortoises from California. Journal of Wildlife Diseases 34, 508-523.

Hulin, C.D., 1925. Geology and Ore Deposits of the Randsburg Quadrangle, California. California State Mining Bureau Bulletin, vol. 95. Sacramento, CA.

Jacobson, E.R., Gaskin, J.M., Brown, M.B., Harris, R.K., Gardiner, C.H., LaPointe, J.L., Adams, H.P., Reggiardo, C., 1991. Chronic upper respiratory tract disease of free ranging desert tortoises (Xerobates agassizii). Journal of Wildlife Diseases 27, 296-316. 
Jacobson, E.R., Wronski, T.J., Schumacher, J., Reggiardo, C., Berry, K.H., 1994. Cutaneous dyskeratosis in freeranging desert tortoises, Gopherus agassizii, in the Colorado Desert of Southern California. Journal of Zoo and Wildlife Medicine 25, 68-81.

Jennings, W.B., 1993. Foraging ecology of the desert tortoise (Gopherus agassizii) in the western Mojave Desert. M.S. Thesis, University of Texas, Arlington.

Jennings, W.B., 2001. Comparative flowering phenology of plants in the western Mojave Desert. Madroño 48, $162-171$.

Jennings, W.B., 2002. Diet selection by the desert tortoise in relation to the flowering phenology of ephemeral plants. Chelonian Conservation and Biology 4, 353-358.

Jennings, C.W., Burnett, J.L., Troxel, B.W. (Compilers), 1962. Geologic Map of California, Trona Sheet. California Division of Mines and Geology, Sacramento. 1 sheet, scale 1:250,000.

Lemmon, D.M., Dorr, J.V.N., 2nd., 1941. Tungsten deposits of the Atolia district, San Bernardino and Kern Counties, California. In: Roberts, R.J., Thayer, T.P., Lemmon, D.W., et al., Strategic Minerals Investigations 1940. US Geological Survey Bulletin 922, vol. 1, pp. 205-245, (Chapters A-K).

Lepp, N.W., 1981. Effect of Heavy Metal Pollution on Plants, vol. 1. Applied Science Publishers, New Jersey.

Marlow, R.W., Tollestrup, K., 1982. Mining and mineral exploitation of natural mineral deposits by the desert tortoise, Gopherus agassizii. Animal Behavior 30, 475-478.

Miller, E.L., Sutter, J.F., 1982. Structural geology and ${ }^{40} \mathrm{Ar}-{ }^{39} \mathrm{Ar}$ geochronology of the Goldstone-Lane Mountain area, Mojave Desert, California. Geological. Society of America Bulletin 93, 1191-1207.

Morafka, D.J., Berry, K.H., 2002. Is Gopherus agassizii a desert-adapted tortoise, or an exaptive opportunist? Implications for tortoise conservation. Chelonian Conservation and Biology 4, 263-287.

Motooka, J., 1996. Organometallic halide extraction for 10 elements by inductively coupled plasma-atomic emission spectrometry. In: Arbogast, B.F. (Ed.), Analytical Methods Manual for the Mineral Resource Surveys Program. US Geological Survey Open-File Report 96-525, pp. 102-108.

Nagy, K.A., Medica, P.A., 1986. Physiological ecology of desert tortoises in southern Nevada. Herpetologica 42, 73-92.

Oftedal, O.T., 2002. Nutritional ecology of the desert tortoise in the Mohave and Sonoran deserts. In: Van Devender, T.R. (Ed.), The Sonoran Desert Tortoise: Natural History, Biology, and Conservation. University of Arizona Press and Arizona-Sonora Desert Museum, Tucson, pp. 94-241.

O'Leary, R.M., Hageman, P.L., Crock, J.G., 1996. Mercury in water, geologic, and plant materials by continuous flow-cold vapor-atomic absorption spectrometry. In: Arbogast, B.F. (Ed.), Analytical Methods Manual for the Mineral Resource Surveys Program. US Geological Survey Open-File Report 96-525, pp. 42-55.

Prose, D.V., 1985. Persisting effects of armored military maneuvers on some soils of the Mojave Desert. Environmental Geology Water and Sciences 7, 163-170.

Ruby, D.E., Niblick, H.A., 1994. A behavioral inventory of the desert tortoise: development of an ethogram. Herpetological Monographs 8, 88-102.

Seltzer, M.D., Berry, K.H., 2005. Laser ablation ICP-MS profiling and semiquantitative determination of trace element concentrations in desert tortoise shells: documenting the uptake of elemental toxicants. Science of the Total Environment 339, 253-265.

Simberloff, D., 1998. Flagships, umbrellas, and keystones: is single-species management passé in the landscape era? Biological Conservation, 247-257.

Speidel, D.H., Agnew, A.F., 1982. The Natural Geochemistry of Our Environment. Westview Press, Boulder, CO.

Sutherland, R.A., Tolosa, C.A., Tack, F.M.G., Verloo, M.G., 2000. Characterization of selected element concentrations and enrichment ratios in background and anthropogenically impacted roadside areas. Archives of Environmental Contamination and Toxicology 38, 428-438.

Taylor, S.R., McLennan, S.M., 1995. The geochemical evolution of the continental crust. Review of Geophysics $33,241-265$.

Troxel, B.W., Morton, P.K., 1962. Mines and mineral resources of Kern County, California. California Division of Mines and Geology, County Report 1.

Van Devender, T.R., Averill-Murray, R.C., Esque, T.C., Holm, P.A., Dickinson, V.M., Schwalbe, C.R., Wirt, E.B., Barrett, S.L., 2002. Grasses, mallows, desert vine, and more. In: Van Devender, T.R. (Ed.), The Sonoran Desert Tortoise: Natural History, Biology, and Conservation. University of Arizona Press and ArizonaSonora Desert Museum, Tucson, pp. 159-193. 
Walker, J.D., Martin, M.W., Glazner, A.F., 2002. Late Paleozoic to Mesozoic development of the Mojave Desert and environs, California. In: Glazner, A.F., Walker, J.D., Bartley, J.M. (Eds.), Geologic Evolution of the Mojave Desert and Southwestern Basin and Range. Geological Society of America Memoir $195,1-18$.

Wedepohl, K.H., 1995. The composition of the continental crust. Geochimica et Cosmochimica Acta 59, $1217-1232$. 